Prepared in cooperation with Keweenaw Bay Indian Community

\title{
Water Quality and Hydrology of the Silver River Watershed, Baraga County, Michigan, 2005-08
}

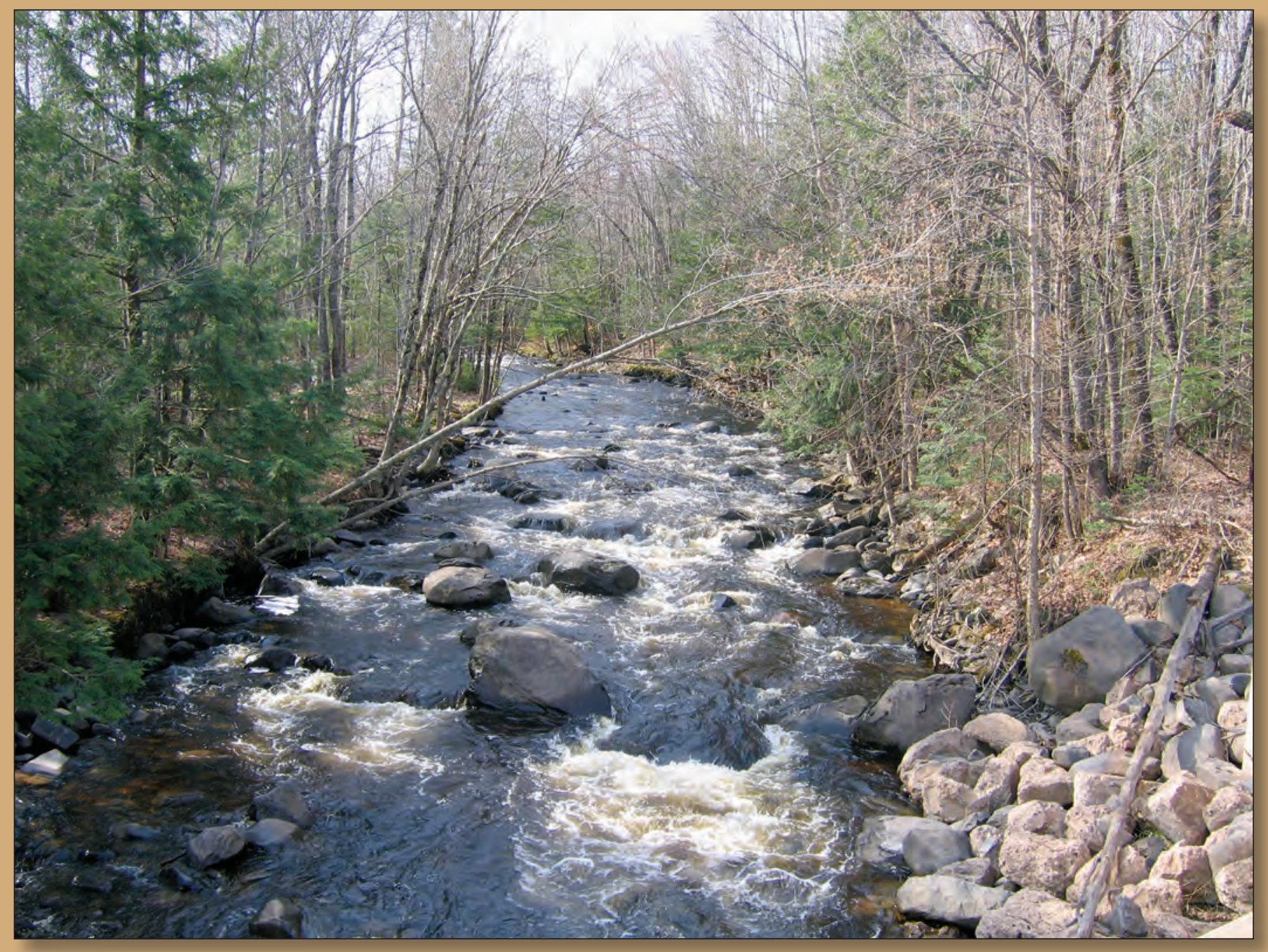

Scientific Investigations Report 2010-5050 



\section{Water Quality and Hydrology of the Silver River Watershed, Baraga County, Michigan, 2005-08}

By Thomas L. Weaver, Daniel J. Sullivan, Cynthia M. Rachol, and James M. Ellis

Prepared in cooperation with Keweenaw Bay Indian Community

Scientific Investigations Report 2010-5050 


\title{
U.S. Department of the Interior \\ KEN SALAZAR, Secretary \\ U.S. Geological Survey \\ Marcia K. McNutt, Director
}

\section{U.S. Geological Survey, Reston, Virginia: 2010}

\author{
For more information on the USGS — the Federal source for science about the Earth, its natural and living resources, \\ natural hazards, and the environment, visit http://www.usgs.gov or call 1-888-ASK-USGS \\ For an overview of USGS information products, including maps, imagery, and publications, \\ visit http://www.usgs.gov/pubprod \\ To order this and other USGS information products, visit http://store.usgs.gov
}

\begin{abstract}
Any use of trade, product, or firm names is for descriptive purposes only and does not imply endorsement by the U.S. Government.

Although this report is in the public domain, permission must be secured from the individual copyright owners to reproduce any copyrighted materials contained within this report.
\end{abstract}

Suggested citation:

Weaver, T.L., Sullivan, D.J., Rachol, C.M., and Ellis, J.M., 2010, Water quality and hydrology of the Silver River Watershed, Baraga County, Michigan, 2005-08: U.S. Geological Survey Scientific Investigations Report 2010-5050, 66 p. 


\section{Contents}

Abstract
Purpose and Scope
Previous Studies and Data-Collection Efforts
Description of the Study Area
Climate
Geologic Setting

Water Quality of Streams in the Silver River Watershed ................................................................20

Field Water-Quality Parameters, Major Ions, Alkalinity, Nutrients, Metals, and Cyanide......20

Field Water-Quality Parameters, Major Ions, and Alkalinity ............................................20

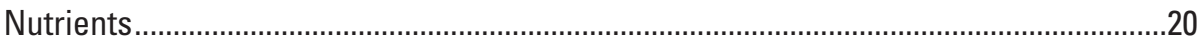

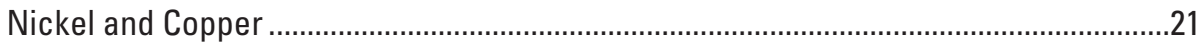

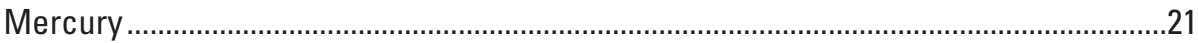

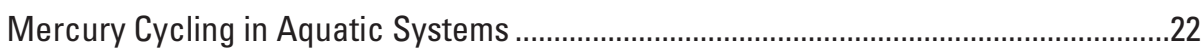

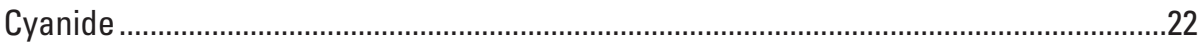

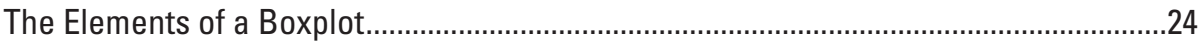

Statistical Analysis of Water-Quality Data and Comparison to Water-Quality Guidelines.....24

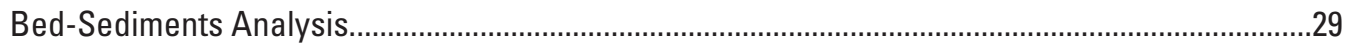

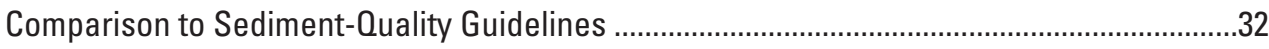

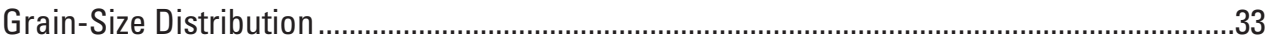

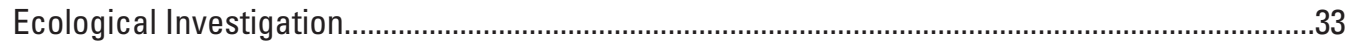

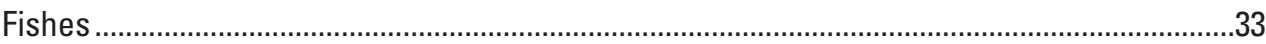

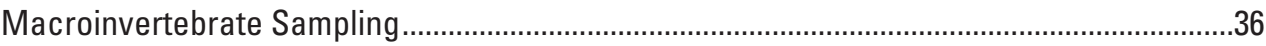

Summary and Conclusions........................................................................................................ 


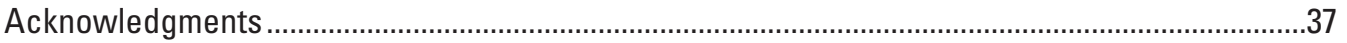

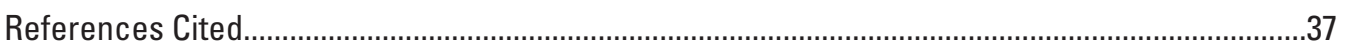

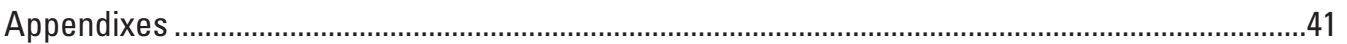

\section{Figures}

1-5. Maps showing:

1. Location of Silver River Watershed study area, Baraga County, Michigan ..............2

2. Silver River Watershed showing topographic features, U.S. Geological Survey (USGS) surface-water gaging stations and sampling sites, and Keweenaw Bay Indian Community (KBIC) surface-water sampling sites, Baraga County, Michigan

3. Silver River Watershed showing land cover, topographic features, and U.S. Geological Survey (USGS) surface-water gaging stations and sampling sites, Baraga County, Michigan

4. Silver River Watershed showing Quaternary geology, topographic features, and U.S. Geological Survey (USGS) surface-water gaging stations and sampling sites, Baraga County, Michigan.

5. Silver River Watershed showing bedrock geology, topographic features, and U.S. Geological Survey (USGS) surface-water gaging stations and sampling sites, Baraga County, Michigan

6-14. Photographs showing:

6. U.S. Geological Survey hydrologic technician examining low-water control downstream of bridge at USGS streamgage 04043126

prior to ecological sampling

7. U.S. Geological Survey streamgage at upper Silver River (04043126) during installation

8. View looking upstream at Silver River at Arvon Road

(U.S. Geological Survey site 04043131) during moderate streamflow on April 20, 2006, and again during high streamflow on April 23, 2008

9. View looking upstream at upper Gomanche Creek at Indian Road

(U.S. Geological Survey site 04043135) from Indian Road, May 10, 2005

10. View looking upstream at East Branch Tributary to Gomanche Creek at Indian Road (U.S. Geological Survey site 04043137) from Indian Road, May 10, 2005

11. View looking upstream at West Branch Tributary to Gomanche Creek (U.S. Geological Survey site 04043138) from unnamed logging road, May 11, 2005

12. View looking upstream at a concrete culvert at the Indian Road crossing of Gomanche Creek (U.S. Geological Survey streamgage 04043140), May 11, 2005.

13. U.S. Geological Survey streamage at Gomanche Creek at Indian Road (04043140)

14. Dakota Creek at unnamed logging-road crossing

(U.S. Geological Survey site 04043146), May 12, 2005

15. Aquatic mercury cycle illustrating the complexities of mercury-cycling pathways in aquatic environments. 
16-20. Boxplots showing:

16. Concentrations of major ions in 80 water-quality samples,

Silver River Watershed, Michigan, 2005-08.

17. Concentrations of metals in 80 water-quality samples,

Silver River Watershed, Michigan, 2005-08.

18. Concentrations of nutrients in 80 filtered $(A)$ and unfiltered

(B) water-quality samples, Silver River Watershed, Michigan, 2005-08

19. Concentration of metals in seven bed-sediment quality samples,

Silver River Watershed, Michigan, 2005-08.

20. Concentration of metals in seven bed-sediment samples compared to sediment-quality guidelines, Silver River Watershed, Michigan, 2005-08.

21-23. Photographs showing:

21. U.S. Geological Survey employees processing adult brook trout at Dakota Creek (site 04043146), August 26, 2008.

22. U.S. Geological Survey employee using a $D$-frame kick net for macroinvertebrate sampling at Dakota Creek (site 04043146) ..... .36

23. Macroinvertebrates and detritus in sorting tray

\section{Tables}

1. Land cover in the study area, Baraga County, Michigan................................................

2. Mean monthly and mean annual temperature for 2005-08, measured by the National Oceanic and Atmospheric Administration observer at Herman, Michigan

3. Monthly and annual precipitation for $2005-08$, measured by the National Oceanic and Atmospheric Administration observer at Herman, Michigan

4. U.S. Geological Survey site number, station name, latitude, longitude, drainage area, and wetland area for water-quality sampling and streamflow-measurement sites in the study area, Baraga County, Michigan

5. Select U.S. Geological Survey National Water Quality Laboratory method detection limits, by sampling date

6. U.S. Geological Survey National Water Quality Laboratory codes, schedules, and respective analytes used for sampling in the Silver River Watershed, Michigan, 2005-08.

7. Sensitivity of surface-water bodies to acid rain; guidelines for Wisconsin....................20

8. Concentrations of total mercury and methylmercury in unfiltered water samples from the Silver River Watershed, Michigan

9. Human non-cancerous, final chronic, and aquatic-maximum criteria values for select constituents as defined by the Michigan Department of Environmental Quality

10. Ambient water-quality criteria for select nutrients as defined by the U.S. Environmental Protection Agency within Nutrient Ecoregion VIII, Sub-ecoregion 50

11. Consensus-based sediment-quality guidelines for freshwater ecosystems

12. Bed-sediment grain-size distribution for selected sites in the

Silver River Watershed, Michigan 
13. Summary of fish communities collected at sites in the Silver River Watershed, Michigan.

14. Concentrations of trace-elements in brook-trout tissue samples taken

from the Silver River Watershed, Michigan.

\section{Appendixes}

1A. Physical properties and concentrations of major elements, solids, nutrients, metals, suspended solids, and cyanide, Silver River upstream

from East Branch near L'Anse, Baraga County, Michigan

1B. Physical properties and concentrations of major elements, solids, nutrients, metals, suspended solids, and cyanide, Silver River at

Arvon Road near L'Anse, Baraga County, Michigan

1C. Physical properties and concentrations of major elements, solids, nutrients, metals, suspended solids, and cyanide, upper Gomanche Creek at Indian Road near Herman, Baraga County, Michigan

1D. Physical properties and concentrations of major elements, solids, nutrients, metals, suspended solids, and cyanide, East Branch Tributary to Gomanche Creek at Indian Road near Herman, Baraga County, Michigan.

1E. Physical properties and concentrations of major elements, solids, nutrients, metals, suspended solids, and cyanide, West Branch Tributary to Gomanche Creek near Herman, Baraga County, Michigan

1F. Physical properties and concentrations of major elements, solids, nutrients, metals, suspended solids, and cyanide, Gomanche Creek at Indian Road near L'Anse, Baraga County, Michigan

1G. Physical properties and concentrations of major elements, solids, nutrients, metals, suspended solids, and cyanide, Dakota Creek at trail crossing near L'Anse, Baraga County, Michigan .

1H. Physical properties and concentrations of major elements, solids, nutrients, metals, suspended solids, and cyanide, Silver River near L'Anse, Baraga County, Michigan

2. Physical properties and concentrations of major elements, nutrients, and metals in bed-sediment samples, Silver River Watershed, Michigan

3A. Results of macroinvertebrate sampling, Silver River upstream of East Branch near L'Anse, Baraga County, Michigan.

3B. Results of macroinvertebrate sampling, Silver River at Arvon Road near L'Anse, Baraga County, Michigan.

3C. Results of macroinvertebrate sampling, upper Gomanche Creek at Indian Road near Herman, Baraga County, Michigan

3D. Results of macroinvertebrate sampling, East Branch Tributary to Gomanche Creek at Indian Road near Herman,Baraga County, Michigan.

3E. Results of macroinvertebrate sampling, West Branch Tributary to Gomanche Creek near Herman, Baraga County, Michigan.

3F. Results of macroinvertebrate sampling, Gomanche Creek at Indian Road near L'Anse, Baraga County, Michigan. 
3G. Results of macroinvertebrate sampling, Dakota Creek at trail crossing near L'Anse, Baraga County, Michigan.

3H. Results of macroinvertebrate sampling, Silver River near L'Anse, Baraga County, Michigan..

\section{Inset Boxes}

1. Mercury Cycling in Aquatic Systems...

2. The Elements of a Box Plot 


\section{Conversion Factors, Vertical Datum, and Abbreviations}

\begin{tabular}{lcl}
\hline \multicolumn{1}{c}{ Multiply } & By & \multicolumn{1}{c}{ To obtain } \\
\hline inch (in.) & Length & \\
millimeter (mm) & 25.40 & millimeter $(\mathrm{mm})$ \\
inch (in.) & 0.03937 & inch (in.) \\
centimeter $(\mathrm{cm})$ & 2.54 & centimeter $(\mathrm{cm})$ \\
foot $(\mathrm{ft})$ & 0.3937 & inch (in.) \\
meter $(\mathrm{m})$ & 0.3048 & meter $(\mathrm{m})$ \\
mile $(\mathrm{mi})$ & 3.281 & foot $(\mathrm{ft})$ \\
\hline & 1.609 & kilometer $(\mathrm{km})$ \\
\hline acre & Area & \\
square mile $\left(\mathrm{mi}^{2}\right)$ & 0.4047 & hectare $(\mathrm{ha})$ \\
& 2.590 & square kilometer $\left(\mathrm{km}^{2}\right)$ \\
\hline cubic foot per second $\left(\mathrm{ft}^{3} / \mathrm{s}\right)$ & Flow rate & \\
cubic foot per second per square & 0.02832 & cubic meter per second $\left(\mathrm{m}^{3} / \mathrm{s}\right)$ \\
$\quad$ mile $\left[\left(\mathrm{ft}^{3} / \mathrm{s}\right) / \mathrm{mi}^{2}\right]$ & 0.01093 & cubic meter per second per square \\
inch per year $(\mathrm{in} / \mathrm{yr})$ & 25.40 & kilometer $\left[\left(\mathrm{m}^{3} / \mathrm{s}\right) / \mathrm{km}^{2}\right]$ \\
\end{tabular}

Temperature in degrees Celsius $\left({ }^{\circ} \mathrm{C}\right)$ may be converted to degrees Fahrenheit $\left({ }^{\circ} \mathrm{F}\right)$ as follows:

${ }^{\circ} \mathrm{F}=\left(1.8 x^{\circ} \mathrm{C}\right)+32$

Temperature in degrees Fahrenheit $\left({ }^{\circ} \mathrm{F}\right)$ may be converted to degrees Celsius $\left({ }^{\circ} \mathrm{C}\right)$ as follows:

${ }^{\circ} \mathrm{C}=\left({ }^{\circ} \mathrm{F}-32\right) / 1.8$

In this report, altitude or elevation refers to vertical distance above the National Geodetic Vertical Datum of 1929 (NGVD 29) — a geodetic datum derived from a general adjustment of the first-order level nets of the United States and Canada, formerly called sea level Datum of 1929.

Runoff is the quantity of water that is discharged, or "runs-off" from a drainage basin during a given time period. Runoff data in this study are reported as mean discharge per unit of drainage area in cubic feet per second per square mile $\left[\left(\mathrm{ft}^{3} / \mathrm{s}\right) / \mathrm{mi}^{2}\right]$.

Specific conductance is given in microsiemens per centimeter at 25 degrees Celsius $(\mu \mathrm{S} / \mathrm{cm}$ at $\left.25^{\circ} \mathrm{C}\right)$.

Concentrations of chemical constituents in water and sediments are given in milligrams per liter $(\mathrm{mg} / \mathrm{L})$, micrograms per liter $(\mu \mathrm{g} / \mathrm{L})$, nanograms per liter $(\mathrm{ng} / \mathrm{L})$, micrograms per gram $(\mu \mathrm{g} / \mathrm{g})$, or micrograms per kilogram $(\mu \mathrm{g} / \mathrm{kg}$ ). For concentrations less than $7,000 \mathrm{mg} / \mathrm{L}$, the numerical value is the same as for concentrations in parts per million. 


\section{Abbreviations}

Water year is the 12-month period from October 1 through September 30. The water year is designated by the calendar year in which it ends. For example, the year starting October 1, 2008 and ending September 30, 2009 is called the "2009 water year."

\begin{tabular}{ll} 
AMLE & adjusted maximum likelihood estimation \\
AMV & aquatic maximum value \\
DOC & dissolved organic carbon \\
FCV & final chronic value \\
GLEAS & Great Lakes Environmental Assessment Section \\
HCV & human cancer value \\
HNV & human non-cancerous value \\
KBIC & Keweenaw Bay Indian Community \\
LRL & laboratory reporting level \\
LT-MDL & long-term method detection limit \\
MDEO & Michigan Department of Environmental Quality \\
MDL & method detection limit \\
MRL & minimum reporting level \\
NFM & national field manual \\
NOAA & National Oceanic and Atmospheric Administration \\
NWIS & National Water Information System \\
NWOL & National Water Quality Laboratory \\
OAPP & Quality-Assurance Project Plan \\
OA/OC & quality assurance/quality control \\
PAHs & polycyclic aromatic hydrocarbons \\
PCBs & polychlorinated biphenyls \\
PEC & probable effect concentration \\
TEC & threshold effect concentration \\
USEPA & U.S. Environmental Protection Agency \\
USGS & U.S. Geological Survey \\
VA & visual accumulation \\
WV & wildlife value \\
\hline
\end{tabular}





\title{
Water Quality and Hydrology of the Silver River Watershed, Baraga County, Michigan, 2005-08
}

\author{
By Thomas L. Weaver, Daniel J. Sullivan, Cynthia M. Rachol, and James M. Ellis
}

\section{Abstract}

The Silver River Watershed comprises about 69 square miles and drains part of northeastern Baraga County, Michigan. For generations, tribal members of the Keweenaw Bay Indian Community have hunted and fished in the watershed. Tribal government and members of Keweenaw Bay Indian Community are concerned about the effect of any development within the watershed, which is rural, isolated, and lightly populated. For decades, the area has been explored for various minerals. Since 2004, several mineral-exploration firms have been actively investigating areas within the watershed; property acquisition, road construction, and subsurface drilling have taken place close to tributary streams of the Silver River.

The U.S. Geological Survey, in cooperation with Keweenaw Bay Indian Community, conducted a multi-year water-resources investigation of the Silver River Watershed during 2005-08. Methods of investigation included analyses of streamflow, water-quality sampling, and ecology at eight discrete sites located throughout the watershed. In addition, three continuous-record streamgages located within the watershed provided stage, discharge, specific conductance, and water-temperature data on an hourly basis.

Water quality of the Silver River Watershed is typical of many streams in undeveloped areas of Upper Michigan. Concentrations of most analytes typically were low, although several exceeded applicable surface-water-quality standards. Seven samples had concentrations of copper that exceeded the Michigan Department of Environmental Quality standards for wildlife, and one sample had concentrations of cyanide that exceeded the same standards. Concentrations of total mercury at all eight sampling sites exceeded the Great Lakes Basin water-quality standard, but the ratio of methylmercury to total mercury was similar to the 5 to 10 percent found in most natural waters. Concentrations of arsenic and chromium in bed sediments were near the threshold-effect concentration. A qualitative ecological assessment of fishes and macroinvertebrates showed that intolerant salmonids were present at most sampled sites, and macroinvertebrate communities were indicative of near-excellent or excellent conditions at all eight sites. This baseline information will aid in an ongoing monitoring effort designed to protect the water resources of the Silver River Watershed.

\section{Introduction}

The Silver River is located in the northeastern part of Baraga County in the Upper Peninsula of Michigan (fig. 1).

Much of the western half of the Silver River Watershed lies within the Keweenaw Bay Indian Community (KBIC) Reservation, although the majority of the land within the watershed is not tribally owned at the present time (2009). Water plays an integral role in the lives of KBIC Tribal members who have fished and hunted on Lake Superior, Keweenaw and Huron Bays, and waters in the Silver River Watershed for generations. Chippewa (or Ojibwa) Indians have lived in the northern Great Lakes Basin for centuries and have depended upon the Great Lakes and tributary streams for sustenance and transportation since their arrival.

Until recently, most water-resource management issues within the Silver River Watershed have been related to logging activities, with typical problems related to stream crossings and erosion. In 2004, however, exploration for metal-bearing deposits within the watershed began in earnest, spurred on by a worldwide surge in metal prices.

Tribal government and members of KBIC are concerned about the short-term effects of mining within the Silver River Watershed, including additional vehicular traffic, accessroad building, surface-plant construction, dust, and erosion. Potential long-term effects include destruction of forests and wetland areas and degradation of water quality within the Silver River, Huron, and Keweenaw Bay Watersheds and ultimately, Lake Superior. The U.S. Geological Survey (USGS) entered into a cooperative agreement with KBIC to (1) evaluate streamflow and water quality, (2) conduct an ecological assessment of the Silver River Watershed, (3) establish a database of baseline conditions, and (4) address concerns of KBIC tribal government and members. The study was conducted during 2005-08, and the results of that effort are summarized in this report.

\section{Purpose and Scope}

The purpose of this study was to (1) sample field waterquality parameters, major ions, nutrients, trace metals, cyanide, and suspended solids from eight sites within the Silver 


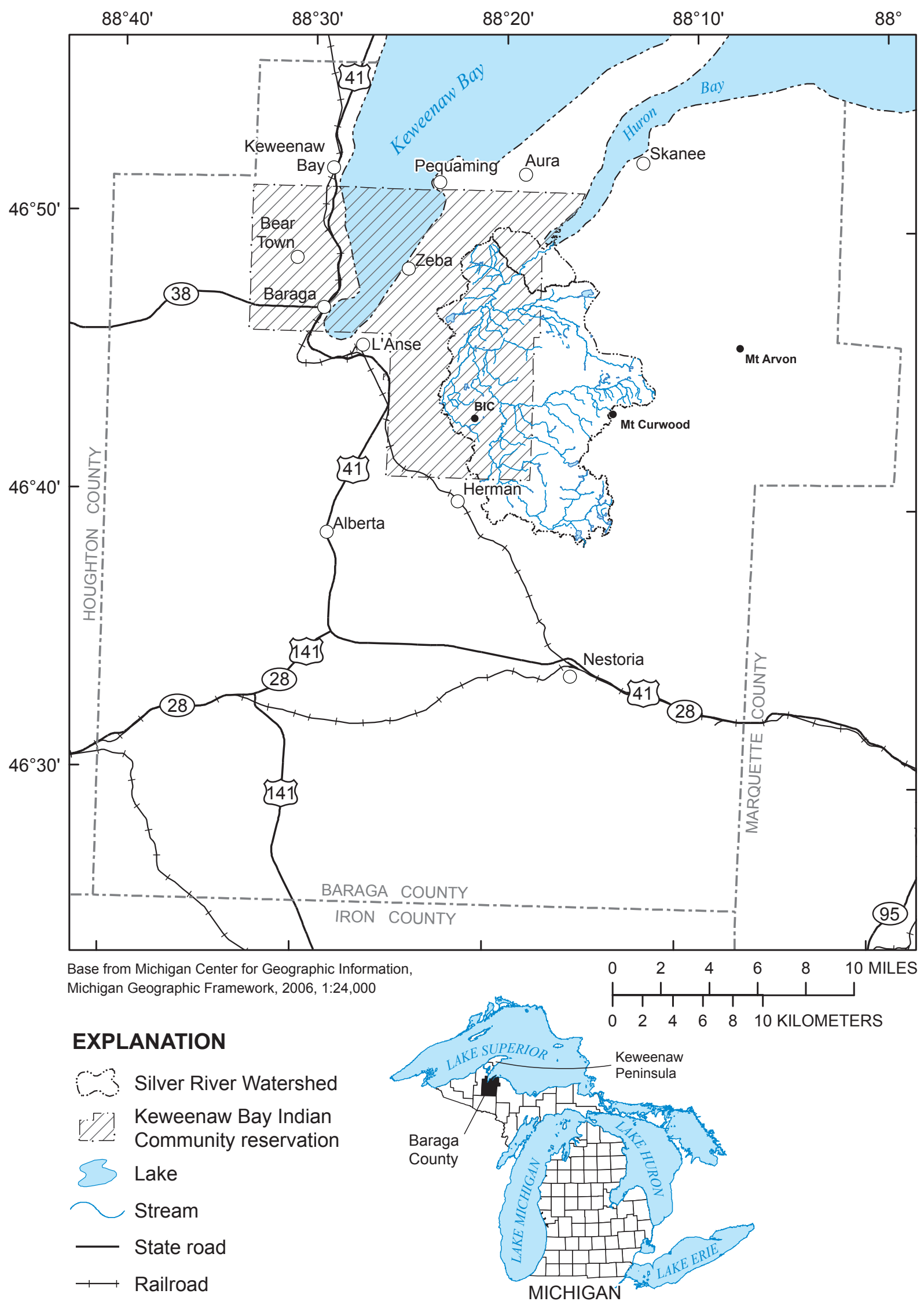

Figure 1. Location of Silver River Watershed study area, Baraga County, Michigan. 
River Watershed during the period 2005-08; (2) establish a baseline surface-water-quality database; (3) describe generalized hydrologic and geologic characteristics of the Silver River Watershed; and (4) measure streamflow at all the sampling sites. Data from previous studies were used to augment the present study, primarily for the purpose of describing hydrology and geology of the watershed. Data collected during this study include streamflow, field water-quality parameters, water-quality samples, and quality-assurance samples at eight sites.

The study was modified somewhat in the later part of the 2008 water year, when KBIC added an ecological component to the study. Sampling of fish tissue for metals analysis and age-dating, bed-sediment sampling for size and metals analysis, and invertebrate sampling and identification were completed in August 2008; the results are summarized in this report.

\section{Previous Studies and Data-Collection Efforts}

Few studies of the Silver River Watershed are known. The USGS conducted a geochemistry study of stream sediments and groundwater wells in the Upper Peninsula of Michigan, as well as surrounding states, primarily to document the presence of uranium, but the analysis also included a number of different metals. A total of 566 stream-sediment and 611 groundwater samples were collected during 1978-79 (Smith, 1997). The USGS also conducted a study of water resources of KBIC (Sweat and Rheaume, 1998).

USGS and KBIC have cooperatively operated a continuous-record streamgage on the Silver River at Skanee Road (04043150) since October 2001 (fig. 2). A water temperature sensor was installed at the site in May 2002 and operated yearround until October 2005, when a multi-probe with water temperature and specific conductance sensors was installed. For quality-assurance and calibration purposes, the multi-probe is operated only from April through November. Stage, discharge (streamflow), specific conductance, and water-temperature data are available on the USGS National Water Information System (NWIS) website at http://waterdata.usgs.gov/nwis.

In October 2007, a continuous-record streamgage was installed at the downstream Gomanche Creek site at Indian Road (04043140) and in September 2008 another continuousrecord streamgage was installed at the upstream Silver River site (04043126) (fig. 2). At the time of gage installation, multi-probes with water temperature and specific conductance sensors also were installed at both sites. The multi-probes have an operational period of April through November, which mimics the multi-probe at streamgage 04043150 . Data for streamgages 04043126 and 04043140 also are available in the USGS NWIS database.

Michigan Technological University through its Aqua Terra Tech student enterprise group, contracted with KBIC to produce groundwater and surface-water flow models of the Silver River Watershed (France and others, 2005; Trahan and others, 2005). The major purpose of constructing the surface-water flow model appears to have been to calibrate the groundwater-flow model. There are some inconsistencies in the surface-water model that are acknowledged by the authors.

Environmental staff from KBIC have been measuring water temperature, dissolved oxygen, specific conductance, and $\mathrm{pH}$, and collecting bacteriological samples at nine sites in the watershed since 1999 (fig. 2).

Several investigations of bedrock geology in the study area previously were completed. Dean Rossell of Kennecott Minerals Company prepared a concise description of their exploration at a site known as the BIC, which includes a full list of relevant geologic references in the area (Rossell, 2008).

\section{Description of the Study Area}

The Silver River Watershed comprises nearly $69 \mathrm{mi}^{2}$ located entirely within Baraga County in the Upper Peninsula of Michigan (fig. 1). The river is composed of several branches and tributaries that drain the northeastern part of the county. Most of the western half of the watershed, including the mouth at Huron Bay, is located within the traditional reservation of KBIC. Altitude of land surface within the watershed ranges from about $602 \mathrm{ft}$ at the mouth to about $1,900 \mathrm{ft}$ near Pages Creek in the eastern part of the watershed. The Keweenawan BIC deposit is hosted in a bedrock high that comprises the highest hill near Indian Road, at an altitude of about 1,540 ft. Branches of Gomanche Creek that drain either side of the Keweenawan BIC deposit flow beneath Indian Road at altitudes of 1,214 and 1,263 ft. High gradients are typical in parts of most of the tributary streams; several spectacular gorges, falls, and rapids cut into the Michigamme Slate are located on the Silver River between Arvon Road and the mouth.

Land cover in the study area is summarized in table 1 and shown on figure 3. No major cities are located within or near the study area, although the Village of L'Anse (fig. 1), with a population of 2,107 (2000 Census), is located several miles

Table 1. Land cover in the study area, Baraga County, Michigan (Michigan Department of Natural Resources, Forest, Mineral, and Fire Management Division, 2003).

$[<$, less than; numerical values in the table are rounded and total is not exactly 100 percent]

\begin{tabular}{lc}
\hline \multicolumn{1}{c}{ Land-cover type } & Percentage of study area \\
\hline Urban & 0.6 \\
Agricultural & $<.1$ \\
Upland open land & 5.3 \\
Forest & 92.0 \\
Water & 1.2 \\
Wetlands & .9 \\
Bare/sparsely vegetated & $<.1$ \\
\hline
\end{tabular}



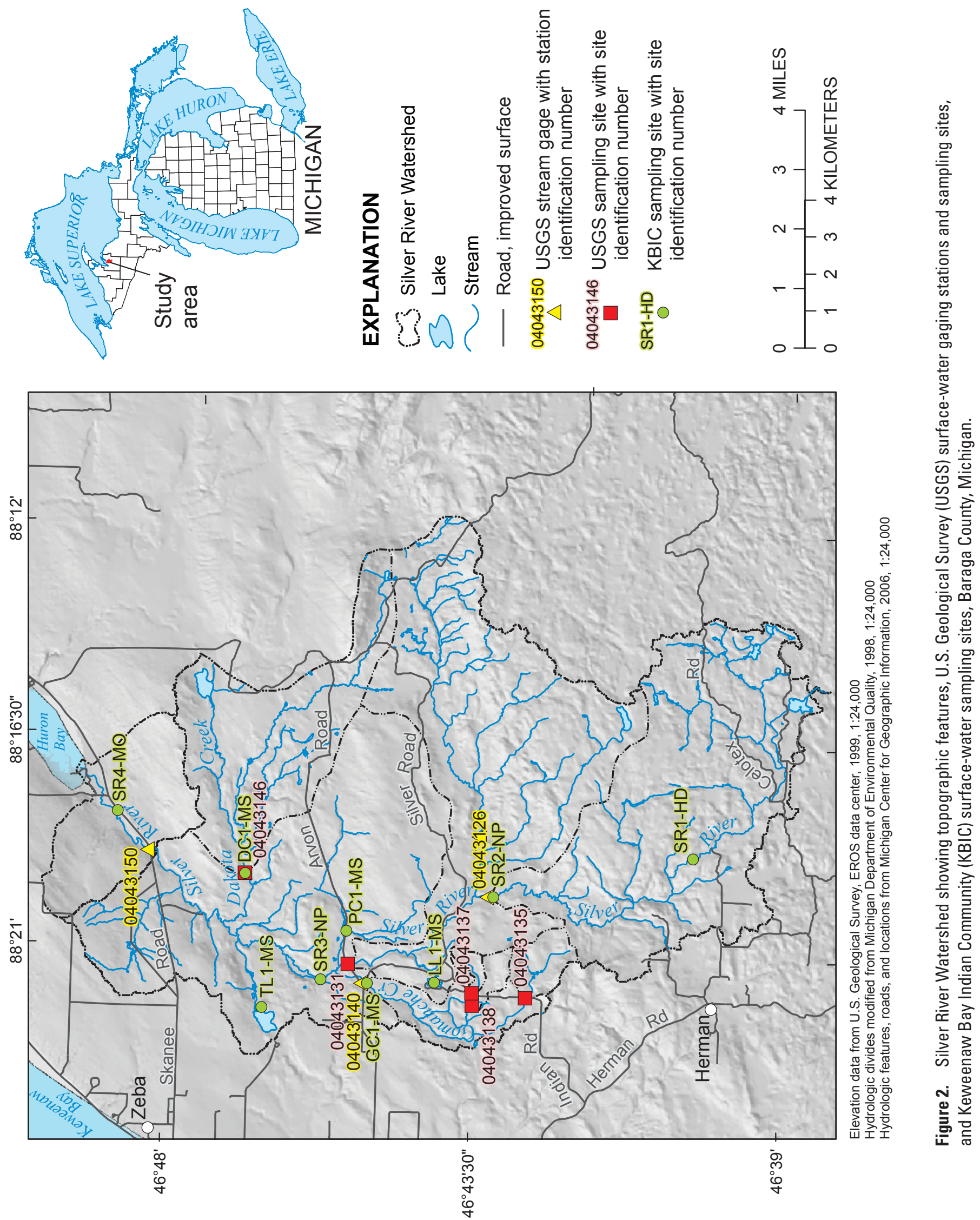

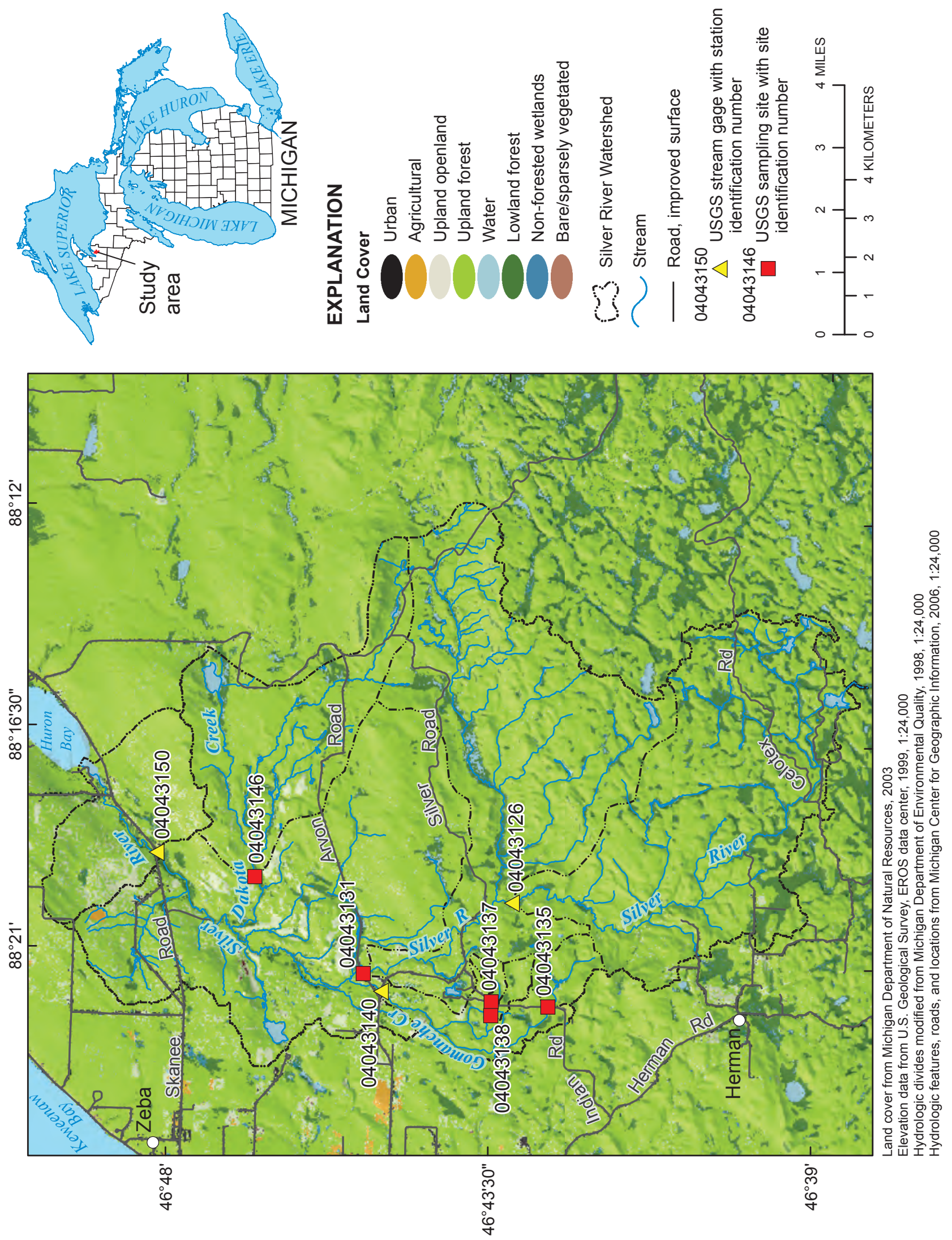

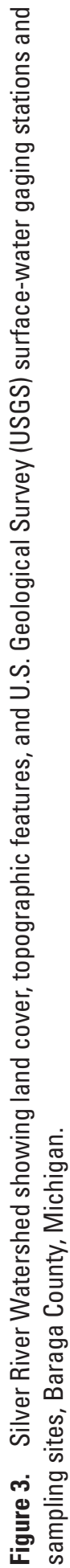


west of the watershed on Keweenaw Bay. Nearly the entire watershed is composed of forested upland, with little development, except for some low-density residential housing along roads, particularly near the mouth at Huron Bay. Logging and recreation are the principal land uses within the study area.

\section{Climate}

Temperature, precipitation, and snowfall data were measured by a National Oceanic and Atmospheric Administration (NOAA) cooperative climate observer at Herman, MI (located just south of the study area; NOAA station 203744) (fig. 1). All climatic data for 2005-08 measured at Herman were accessed at the National Climatic Data Center (2008) or (David Pearson, Hydrologist, National Oceanic and Atmospheric Administration, written commun., 2009).

The climate of the Silver River Watershed study area is typical of the northern Great Lakes Basin. Sweat and Rheaume (1998) reported an average annual precipitation of $100 \mathrm{~cm}$ (39.4 in.) and mean monthly temperatures ranging from about -11 to about $17^{\circ} \mathrm{C}\left(12\right.$ and $63^{\circ} \mathrm{F}$, respectively). Annual precipitation measured at the NOAA station at Herman for 2005-08 was $38.0,25.2,36.6$, and 34.7 in., respectively, and mean monthly temperatures ranged from 5.6 to $65.8^{\circ} \mathrm{F}$. Mean monthly and annual temperatures and monthly and annual total precipitation (rain and rain-equivalent snowfall) for the NOAA station at Herman are included in tables 2 and 3, respectively.

Seasonal variability of precipitation in the watershed is appreciable. Most precipitation falls from May through November, and the least water-equivalent precipitation typically falls from December through April. Mean air temperature for the years $1971-96$ is $40.4^{\circ} \mathrm{F}$ (National Climatic Data Center, 2002), which is nearly equivalent to mean air temperatures measured at Herman during 2005 and 2006, 40.8 and $39.5^{\circ} \mathrm{F}$, respectively (monthly air temperatures were not available for all months during 2007-08). Temperature and precipitation data also have been collected at the KBIC fish hatchery at Pequaming, Michigan (fig. 1), since 2004.

Table 2. Mean monthly and mean annual temperature for 2005-08, measured by the National Oceanic and Atmospheric Administration observer at Herman, Michigan.

[--, incomplete data available; data are in degrees Fahrenheit]

\begin{tabular}{|c|c|c|c|c|c|c|c|c|c|c|c|c|c|}
\hline Year & January & February & March & April & May & June & July & August & September & October & November & December & Annual \\
\hline 2005 & 9.5 & 18.3 & 19.9 & 41.9 & 48.6 & 65.1 & 65.7 & 64.5 & 60.2 & 47.3 & 30.3 & 18.1 & 40.8 \\
\hline 2006 & 24.2 & 12.5 & 22.6 & 41.1 & 49.9 & 58.1 & 65.8 & 60.7 & 49.8 & 36.2 & 30.9 & 22.3 & 39.5 \\
\hline 2008 & 15.3 & 8.9 & 18.2 & 29.4 & 38.9 & 53.2 & 56.9 & -- & -- & 39.6 & 27.4 & 10.5 & -- \\
\hline
\end{tabular}

Table 3. Monthly and annual precipitation for 2005-08, measured by the National Oceanic and Atmospheric Administration observer at Herman, Michigan.

[data are in inches]

\begin{tabular}{|c|c|c|c|c|c|c|c|c|c|c|c|c|c|}
\hline Year & January & February & March & April & May & June & July & August & September & October & November & December & Annual \\
\hline 2005 & 1.15 & 2.15 & 2.19 & 2.42 & 3.70 & 4.33 & 2.65 & 1.76 & 3.68 & 6.64 & 5.14 & 2.15 & 38.0 \\
\hline 2006 & 2.08 & 1.85 & 2.00 & 1.65 & 3.39 & 1.44 & 3.28 & 2.02 & 1.62 & 2.64 & 1.50 & 1.78 & 25.2 \\
\hline 2008 & 1.66 & .99 & 1.72 & 3.76 & 2.36 & 3.08 & 7.54 & 1.93 & 4.33 & 3.03 & 2.67 & 1.66 & 34.7 \\
\hline
\end{tabular}




\section{Geologic Setting}

The land-surface features in Baraga County are affected by the underlying Archean and Precambrian bedrock features and unconsolidated glacial deposits, which overlie the bedrock (Doonan and Byerlay, 1973). Topography of the study area (fig. 2) is quite rugged when compared with most of Michigan. Altitude of land surface ranges from about $600 \mathrm{ft}$ at the mouth of the Silver River to about 1,979 ft at Mt. Arvon, in the eastern part of the county, which is the highest point in Michigan (fig. 1).

\section{Glacial Sediments}

With the exception of some areas where bedrock outcrops at the land surface, landforms including outwash plains, moraines, and till plains created by Pleistocene glacial advance and retreat (melting) are the predominant geomorphologic features of the present-day Upper Peninsula of Michigan, including Baraga County (Farrand and Bell, 1982) (fig. 4). The glacial history of the study area is complex, similar to most other glaciated areas of the Upper Midwest. Based on numerous studies, multiple episodes of Wisconsinan-age glaciation, beginning around 75,000 years ago (Illinois State Geological Survey, 2009), are known to have occurred in the study area. Earlier glacial advances also covered the study area, but glacially derived sediments, which compose most of the presentday unconsolidated deposits overlying bedrock in the study area, are primarily attributed to late Wisconsinan readvances, which occurred as recently as 9,900 years ago. As the ice advanced from the present-day Lake Superior Basin, it formed into lobes and flowed south and west. Baraga County was covered by the Keweenaw Lobe, which was a sublobe separated from the main Superior Lobe by highlands in the Keweenaw Peninsula (fig. 1), northwest of Baraga County. The Keweenaw Lobe moved southwestward in Keweenaw Bay and then spread generally southeastward onto the highlands (Doonan and Byerlay, 1973). As the Keweenaw Lobe melted back to the position of the Keweenaw Moraine, a series of proglacial ponded-meltwater lakes formed, including the area now known as the Baraga Plains. The Marinesco Moraine, which predates the Keweenaw Moraine, trends roughly eastwest, approximately parallel with and immediately south of State Highway M-28 (fig. 1), and covers the southern third of the county. A smaller, northeastward-trending landform was mapped by Leverett (1929) as the Covington Moraine.
The location of the Covington Moraine is roughly parallel to the Keweenaw Moraine and simply may be a landward extension of that landform deposited during the last re-advance around 9,900 years before present. Holocene (post-glacial) sediments largely are confined to areas adjacent to surfacewater bodies, including the area near the mouth of the Silver River.

\section{Bedrock}

The oldest rocks primarily are composed of Lower Precambrian granite and granitic gneiss, and Archean gneisses (Cannon and Ottke, 1999). This bedrock unit stands several hundred feet higher than surrounding bedrock formations and comprises the area called the Peshekee Uplands by Doonan and Byerlay (1973). The two highest points in Michigan, which are both in Baraga County (Mt. Arvon at about 1,979 ft and Mt. Curwood at about 1,978 ft), are both composed of this bedrock unit (fig. 1). Mt. Curwood is located within the study area, although Mt. Arvon is not. The most prolific bedrock unit in the study area is the Middle Cambrian (Animikean) Michigamme Slate, which subcrops (stratigraphically highest bedrock unit) immediately under unconsolidated sediments or outcrops (found at the surface) in the largest part of Baraga County (fig. 5). This unit appears to be a metamorphosed turbidite sequence that is primarily composed of slate, but also contains lesser amounts of quartzite, graywackes, and banded-iron formations in lower sections. The Michigamme Slate outcrops at the Silver River at Arvon Road site (site 04043131) and at the Silver River near L'Anse streamgage (04043150), where it forms the low-water control. Upper Precambrian (Keweenawan) rocks primarily composed of the Jacobsville Sandstone unit are found near the shore of Huron and Keweenaw Bays. In addition to sandstone, the Jacobsville Sandstone also contains interbedded siltstones and shales. Outcrops of Jacobsville Sandstone are visible at the shoreline along U.S. Highway 41 at L'Anse and again near Keweenaw Bay, as well as many other places on or near the shore of Lake Superior. The bedrock unit comprising the Keweenaw $\mathrm{BIC}$ (fig. 5) is an ultramafic/mafic intrusive body believed to be about Keweenawan age as well (Rossell, 2008). The BIC intrudes near the contact of the Archean rock and the Michigamme Formation and rises to about $300 \mathrm{ft}$ more than the surrounding terrain, at an altitude of about 1,540 ft, cross-cutting the Michigamme Formation. 

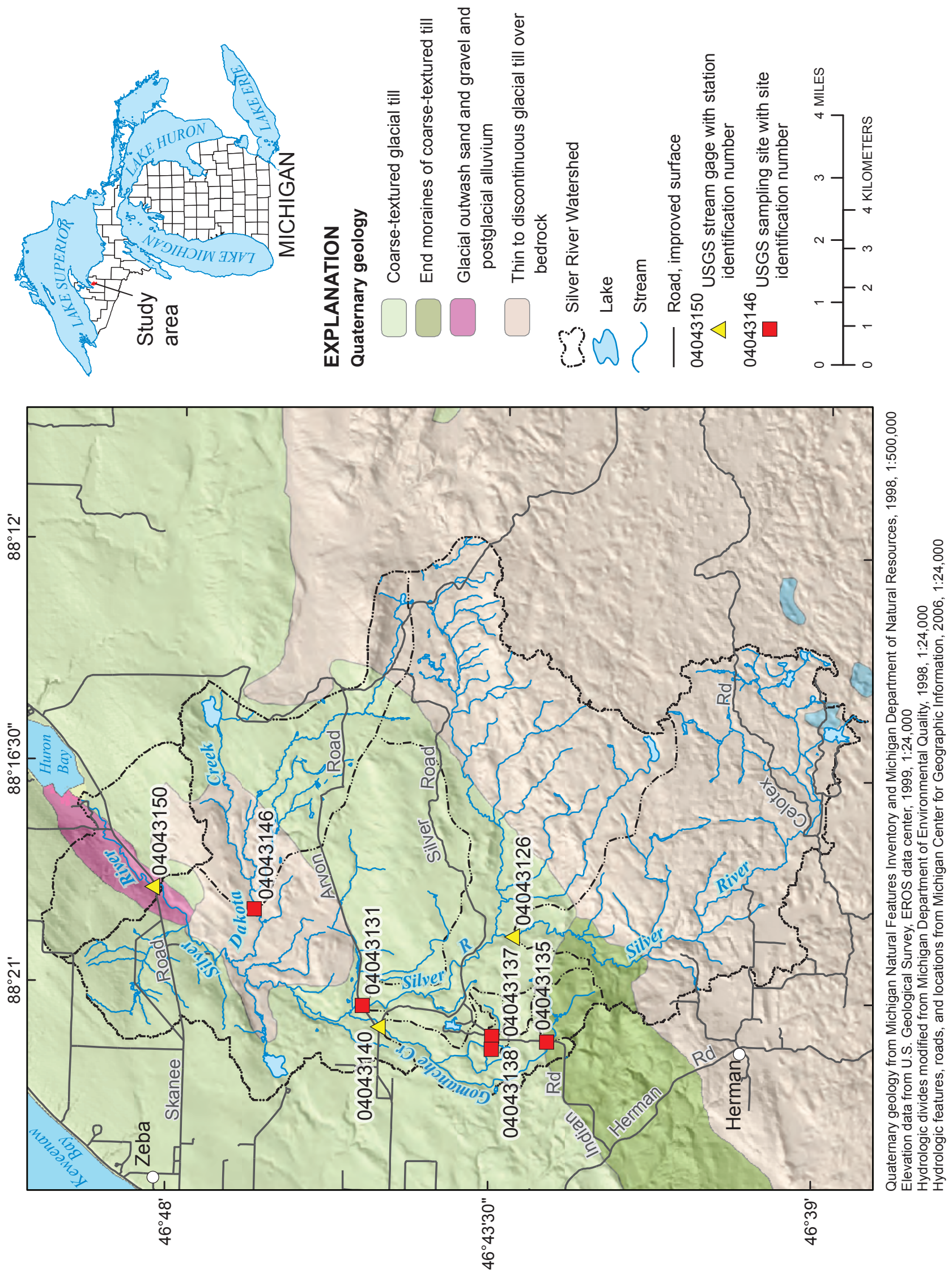

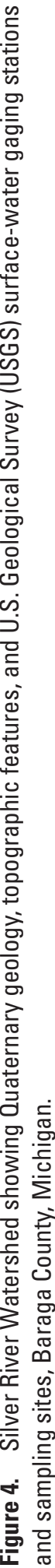



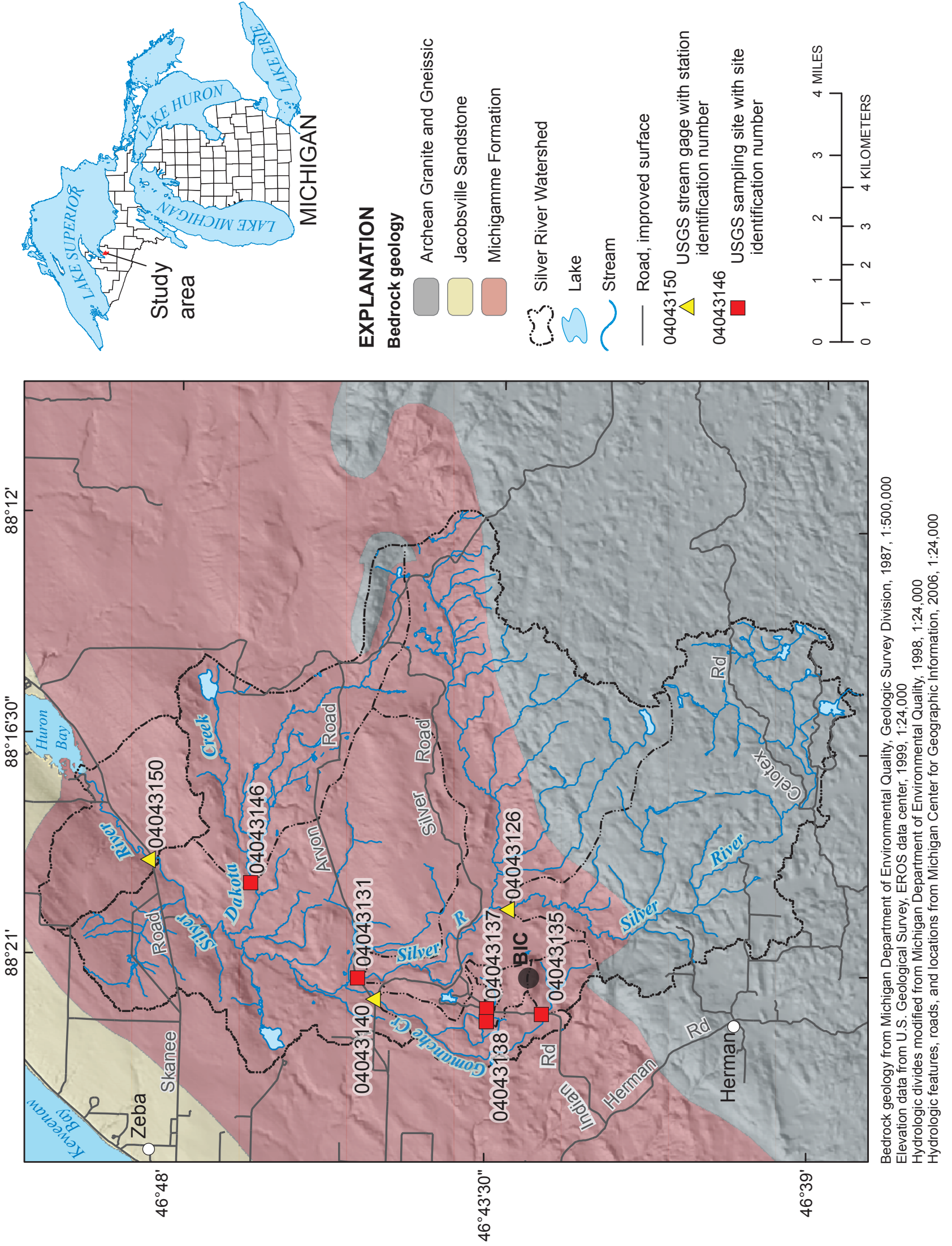

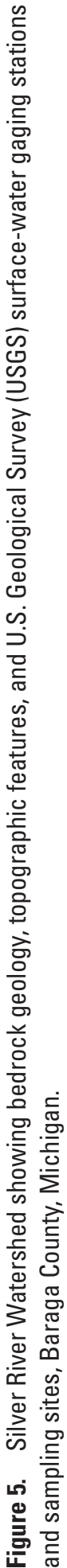




\section{Methods of Data Collection and Analysis}

An unpublished Quality-Assurance Project Plan (QAPP) was prepared by the USGS Michigan Water Science Center and KBIC environmental staff, and approved by the USGS National Water Quality Laboratory (NWQL) and the U.S. Environmental Protection Agency (USEPA) Region 5 prior to data collection. All data collection and analyses were performed, as described in the QAPP, by USGS and KBIC employees at eight sampling sites within the watershed. Geographic-location information and drainage and wetland areas for the eight sites are included in table 4 .

Streamflow was measured using methods described in Carter and Davidian (1968) and Rantz and others (1982), and water-quality data were collected using methods described in the USGS National Field Manual (NFM) for the Collection of Water-Quality Data (variously dated) (available online at http://pubs.water.usgs.gov/twri9A). Water-quality samples were processed at the USGS NWQL following their Quality Assurance/Quality Control (QA/QC) plan with the following exceptions; cyanide samples were analyzed by a USGSapproved contract laboratory, and unfiltered total and methylmercury samples collected in September 2008 were analyzed by the USGS Wisconsin Mercury Research Laboratory in the Wisconsin Water Science Center. Fish-tissue samples were collected and processed using methods described in Moulton and others (2002) and analyzed by laboratories at Texas A\&M University. The fish otoliths, which are parts of the ear, were age dated by a contract laboratory specializing in that procedure. Invertebrate sampling, preservation, and identification followed Michigan Department of Environmental Quality (MDEQ) qualitative biological- and habitat-survey protocols for wadeable streams and rivers (2007). Bed-sediment samples were collected and processed using methods described in USGS NFM Chapter A8, analyzed for metals at the USGS NWQL, and analyzed for grain-size distribution at the Kentucky Water Science Center Sediment Laboratory.

\section{Streamflow}

Streamflow was measured using a current meter or calculated using a stage-discharge rating at all of the datacollection sites during this study, and results are summarized in appendix 1. In addition, streamflow has been monitored on a real-time basis at the Silver River near L'Anse streamgage (04043150) since the beginning of the study. Two additional continuous-record streamgages were established after the study began: Gomanche Creek at Indian Road (04043140) on October 31, 2007, and the Silver River upstream of the East Branch (04043126) on October 1, 2008. Historic and current stage and streamflow data from the continuous-record streamgages are available online at several USGS websites including $h t t p: / / m i$.water.usgs.gov and http://waterdata. usgs.gov/nwis/sw. Sampling locations for this study include streamgages, which are equipped with stage recorders, and miscellaneous sites, hereafter referred to simply as "site", which are not equipped with any equipment.

Table 4. U.S. Geological Survey site number, station name, latitude, longitude, drainage area, and wetland area for water-quality sampling and streamflow-measurement sites in the study area, Baraga County, Michigan.

[USGS, U.S. Geological Survey; mi2, square mile; NA, not applicable; numerical values in the table are rounded to the nearest hundredth, except drainage areas and percentages, which are rounded to the nearest tenth]

\begin{tabular}{|c|c|c|c|c|c|c|}
\hline $\begin{array}{c}\text { USGS } \\
\text { site } \\
\text { number }\end{array}$ & $\begin{array}{l}\text { USGS } \\
\text { station name }\end{array}$ & $\begin{array}{l}\text { Latitude } \\
\text { in degrees }\end{array}$ & $\begin{array}{l}\text { Longitude } \\
\text { in degrees }\end{array}$ & $\begin{array}{l}\text { Drainage area, } \\
\text { in } \mathrm{mi}^{2}\end{array}$ & $\begin{array}{l}\text { Wetland area } \\
\text { in } \mathrm{mi}^{2}\end{array}$ & $\begin{array}{l}\text { Percentage of } \\
\text { basin composed } \\
\text { of wetlands }\end{array}$ \\
\hline 04043126 & $\begin{array}{l}\text { Silver River upstream of } \\
\text { East Branch near L'Anse }\end{array}$ & 46.72 & 88.33 & 16.8 & 4.69 & 27.9 \\
\hline 04043131 & Silver River at Arvon Road near L'Anse & 46.76 & 88.36 & 34.5 & 8.08 & 23.4 \\
\hline 04043135 & $\begin{array}{l}\text { Upper Gomanche Creek at Indian Road } \\
\text { near Herman }\end{array}$ & 46.71 & 88.36 & .9 & .19 & 20.9 \\
\hline 04043137 & $\begin{array}{l}\text { East Branch Tributary to } \\
\text { Gomanche Creek near Herman }\end{array}$ & 46.72 & 88.36 & .2 & .08 & 38.4 \\
\hline 04043138 & $\begin{array}{l}\text { West Branch Tributary to } \\
\text { Gomanche Creek near Herman }\end{array}$ & 46.72 & 88.37 & .3 & .08 & 27.1 \\
\hline 04043140 & $\begin{array}{l}\text { Gomanche Creek at Indian Road } \\
\text { near L'Anse }\end{array}$ & 46.75 & 88.36 & 3.5 & .75 & 21.9 \\
\hline 04043150 & Silver River near L'Anse & 46.80 & 88.32 & 64.7 & 12.46 & 19.2 \\
\hline $\begin{array}{l}\text { Study area } \\
\text { total }\end{array}$ & & NA & NA & 69.8 & 12.80 & 18.3 \\
\hline
\end{tabular}


Streamflow was measured at all sampling sites concurrent with water-quality sampling, with the exception of the Silver River at Arvon Road (site 04043131), which is very rocky and steeply graded for hundreds of feet upstream and downstream of the bridge. At medium to high streamflow, the river becomes too deep to wade and extremely turbulent near the Arvon Road bridge, precluding the prudent use of a suspended current meter as well as a depth-integrated sampler.

Standard USGS techniques were used to measure streamflow (Carter and Davidian, 1968; Rantz and others, 1982), typically with a current meter and wading rod. Each streamflow measurement was given a rating by the hydrographer, ranging from poor to excellent, which is intended to convey the accuracy of a given measurement. A number of factors are considered when rating a discharge measurement, including but not limited to characteristics of the measurement cross section, spacing and number of observation verticals, distribution of flow in the cross section, variability of velocity during the timed interval, and extent of change in stream elevation during the discharge measurement.

The USGS streamgage 04043150 at Silver River near L'Anse was established in October 2001 and was the only site within the Silver River Watershed with a stage-discharge rating during this study. A continuous-record streamgage at Gomanche Creek (04043140) was established in October 2007 but its stage-discharge rating was not fully developed until fall 2008, after all sampling for this study was complete. Typically, a stage-discharge rating is established after streamflow has been measured over a range of stage (gage height) at the site and updated as needed to reflect changes in channel configuration and control over time. A stage-discharge rating table lists a streamflow or discharge for each stage (typically in 0.1 or $0.01 \mathrm{ft}$ increments). At a continuous-data streamgage with an active stage-discharge rating, such as streamgage 04043150 , which records stage every hour, the calculated streamflow values are useable with an acceptable level of confidence even though they were not specifically measured, except during site visits.

\section{Water-Quality Sampling}

Water-quality data were collected using standard techniques and methods described in the USGS NFM (available online at http://pubs.water.usgs.gov/twri9A). Waterquality samples were analyzed at the USGS NWQL following the USGS NWQL QA/QC plan with the following exceptions: cyanide samples were analyzed by a USGS approved contract laboratory, and unfiltered total mercury and methylmercury samples collected in summer 2008 were analyzed by the USGS Wisconsin Mercury Research Laboratory in the Wisconsin Water Science Center.

Spring sampling proceeded ice out (when ice is fully melted on the streams) and was completed as soon as sites became accessible and streamflow was low enough not to damage sampling equipment. Spring sampling in all years was accomplished prior to active vegetation growth. Summer (or low-flow) sampling was accomplished after the streams reached baseflow conditions and while vegetation was still in the growth stage (before any killing frosts). Samples also were collected July 25 and 26, 2006, immediately following a quick-moving thunderstorm that dumped about 2 in. of rain on the field area (National Climatic Data Center, 2008). Field water-quality parameters ( $\mathrm{pH}$, specific conductance, concentration of dissolved oxygen, and water temperature) were measured using a multi-parameter meter, which was calibrated daily following the procedure outlined in the USGS NFM. Samples were collected using a proto-cleaned sampler suitable to the particular streamflow conditions at each site. In shallow, low-velocity streams, this typically was accomplished by use of a handheld grab-sample bottle (the sample bottle is held by hand below the top of the water surface), but at wadeable sites with greater depth and higher velocity streamflows, a DH81 sampler and equal-width-increment protocol were used. At unwadeable sites, typically during spring sampling, either a D-95 depth-integrated sampler or a weighted-point sampler was used. The weighted-point sampler was used only as a last resort, when turbulence or streamflow conditions precluded using the D-95 owing to concerns about equipment damage or loss (typically at site 04043131).

\section{Water-Quality Reporting Levels and Analysis}

The NWQL has established reporting levels for various analytical procedures (Oblinger-Childress and others, 1999), and this section largely is excerpted from that report. In the following sections of this report, tabulated data are reported as "uncensored," "censored," or "estimated." Uncensored data are data reported as an unqualified numerical value. Censored data are reported as less than a particular reporting level; for example, $<0.12$ milligrams per liter $(\mathrm{mg} / \mathrm{L})$. Censored data result from the analyte either not being present or, if seemingly present, an inability to conclusively identify it. Estimated data are reported as qualified numerical values with an "E" before the number; for example, E0.057. Estimated values can be less than, at, or greater than the analytical reporting level. An estimated value less than the reporting level means that the analyte can be identified and measured, but with less than 99-percent confidence that it is present. Estimated values at or above the analytical reporting level can result from a poorperformance record of the analyte with the analytical method, matrix interference, or small sample volume.

Reporting levels used by the USGS NWQL are minimum reporting level (MRL), method detection limit (MDL), longterm method detection limit (LT-MDL), and laboratory reporting level (LRL). The MRL is the lowest measured concentration of an analyte that can be reliably reported. The MDL is the minimum concentration that can be measured and reported with a 99-percent confidence that the analyte is present. The LT-MDL is derived from the standard deviation of a minimum of 24 MDL spike samples over an extended period. The LRL generally is equal to twice the LT-MDL. The probability of reporting an analyte as nondetected when it is present is less 
than 1 percent at the LRL. The LRL is used when the NWQL determines that an MRL is no longer appropriate to a specific analyte or analytical method. Concentrations measured between the LRL and LT-MDL are reported as estimated concentrations.

For constituents with censored values, summary statistics were calculated by use of the adjusted maximum likelihood estimation (AMLE) method (Helsel and Hirsch, 2002). This approach is used when the uncensored data follow a known distribution, which for environmental data usually is a lognormal distribution (Helsel, 2005a). By relying on the detected data to define a hypothetical log-normal distribution that extends below the reporting levels of the analysis, summary statistics that are assumed to represent the whole sample population (uncensored and censored alike) were estimated based on this distribution. Unbiased statistics result from this method if the uncensored data fit an exact log-normal distribution and if the sample size is large ( 24 or more concentrations greater than the reporting level; Helsel and Hirsch, 2002).

Before the AMLE approach was applied, data were carefully scrutinized to ensure that the applicable reporting limits were used in the analysis. Helsel (2005b) stressed caution when examining data that contained censored and estimated values and described the occurrence of insider censoring as being situations where data measured as less than the detection limit are reported as being less than the quantitation, or reporting limit, but the "estimated" values are used for analysis with the same weight as uncensored values even though these values are less than the quantitation limit. This creates an uneven dataset where some data are censored at a higher level than others. For statistical applications, like AMLE, data that should be analyzed at a lower detection level are raised to the same analytical level as the quantitation level, resulting in an upward bias. To remove the bias, the MDL was used as the detection limit for analytes that contained both estimated values and non-detected values (table 5).

\section{Streambed Sediment and Biological Data}

Streambed-sediment samples were collected and processed using methods described in the USGS NFM Chapter A8 (available online at http://pubs.water.usgs.gov/twri9A) and were processed at the USGS Sediment Laboratory located at the Kentucky Water Science Center, Louisville, Ky. Fish-community and fish-tissue samples were collected and processed using methods described in Moulton and others (2002).

Macroinvertebrate sampling, preservation, and identification followed the MDEQ Great Lakes Environmental Assessment Section (GLEAS) 51 procedure for qualitative-biological and habitat-survey protocols for wadeable streams and rivers (2007). The GLEAS 51 procedure has been used extensively

Table 5. Select U.S. Geological Survey National Water Quality Laboratory method detection limits, by sampling date.

[mg/L, milligrams per liter; $\mu \mathrm{g} / \mathrm{L}$, micrograms per liter]

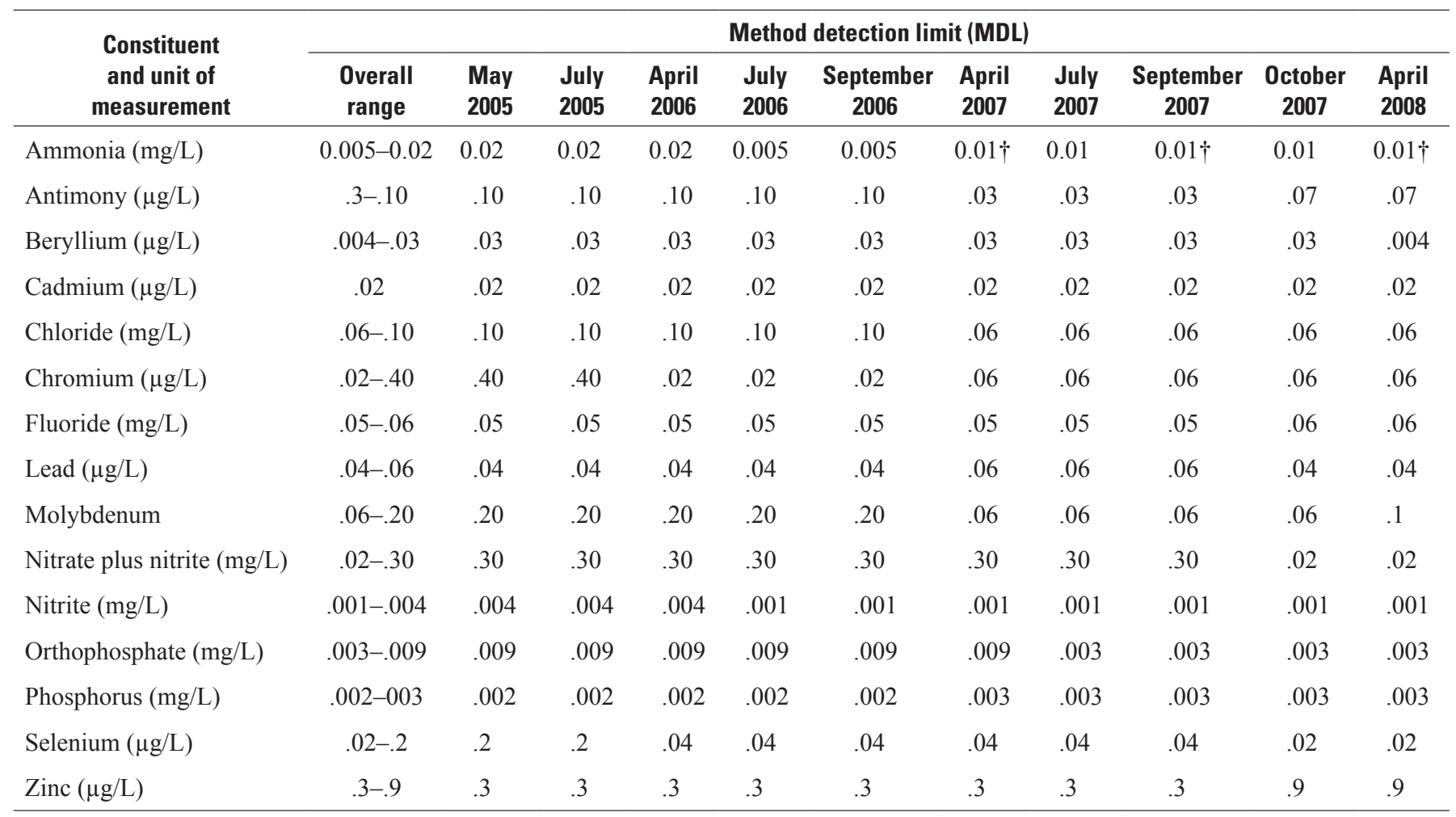

${ }^{\dagger}$ MDL for streamflow-gaging station 04043135 was 0.003 
in Michigan for several years and consists of separate qualitative evaluations of the fish community, macroinvertebrate community, and the habitat quality, completed in that order to minimize disruption of the sampled communities.

Sediment samples were composites of samples collected by hand with a Teflon scoop from each of 5 to 10 depositional zones (submerged during low streamflow) along a reach of approximately $150 \mathrm{~m}$. Samples were collected from the upper $2 \mathrm{~cm}$ (most recent, oxidized layer), and the amount collected depended upon the relative size of the depositional zone. Deposits of fine-grained sediment were sought out and sampled; thus, concentrations represent conditions in depositional areas of the streams, not the average concentrations for sediment throughout the stream reach. A bulk ( $<2 \mathrm{~mm}$ fraction) sample was removed and submitted for particle-size analysis from the composited samples from each site. The remaining sediment was wet-sieved in the field, and the fine $(<0.063 \mathrm{~mm})$ fraction was submitted for trace-element analysis.

Methods for collection and processing of biota (Moulton and others, 2002) included use of plastic implements (Teflon, polypropylene, or polyethylene) where appropriate for trace-element sampling. Quality-control procedures for the collection and processing of biota and sediment included collection of approximately 15 -percent replicate samples and the use of clean techniques to minimize potential contamination. Fish for community and tissue analyses were collected by use of direct-current electrofishing gear. Depending upon stream depth, stage, and other factors, either backpack-mounted or towed-barge electrofishing units were used. The target organism for tissue analysis was the brook trout (Salvelinus fontinalis). After capture, the fish were rinsed in native water, weighed, and measured for total length. Otoliths were collected for age determination. Fish fillets were removed, placed in precleaned glass jars with Teflon-lined lids, frozen on dry ice, and shipped to the laboratory for analysis.

\section{Hydrology of the Silver River Watershed}

The hydrology of the Silver River Watershed was investigated by making discrete streamflow measurements at all eight sampling sites and installing three continuous-record streamgages. Annual mean streamflow and mean annual runoff are now known for each of the continuous-record streamgages showing differences between stream segments. In addition, if loading calculations are required in the future, each waterquality sample has an associated streamflow.

\section{Streamflow}

During this study, streamflow was either measured using a current meter; acoustic Doppler velocimeter; or water-tight container of known capacity, such as a plastic 1-gal. bucket; or calculated using a stage-discharge rating concurrent with water-quality sampling at all of the data-collection sites. The results are summarized in appendix 1 . In addition, streamflow has been monitored on a real-time basis at the Silver River near L'Anse streamgage (04043150) since the beginning of the study. Two additional continuous-record streamgages were established during the study period: Gomanche Creek at Indian Road (04043140) on October 31, 2007, and the Silver River upstream of the East Branch (04043126) on October 1, 2008. Historic and current stage and streamflow data from the continuous-record streamgages are available online at various USGS websites including http://mi.water.usgs.gov and http://waterdata.usgs.gov/nwis/sw.

\section{Silver River Upstream of East Branch}

The Silver River upstream of the East Branch confluence flows under a steel and timber bridge on an unnamed, unimproved road owned by Plum Creek Timber Company (fig. 2). The drainage basin includes an area of about $16.8 \mathrm{mi}^{2}$. The stream channel is low gradient near the bridge and upstream for several hundred feet. Tag alders and other bushes dominate the near-shore vegetation. Water-quality sampling and streamflow measurements both are easily made at this location, which has a gravel-channel bottom except near the bridge, where the channel is quite rocky, including some large boulders (fig. 6). Average runoff will be available after the stagedischarge rating is developed. A continuous-record streamflow gage and a water-quality monitor to measure water temperature and specific conductance (streamgage 04043126) were installed and made operational at this location on September 25, 2008 (fig. 7).

\section{Silver River at Arvon Road}

The drainage basin of Silver River at Arvon Road (site 04043131) includes an area of about $34.5 \mathrm{mi}^{2}$ (fig. 2). The site is located several miles downstream of the confluence with the East Branch Silver River and a few hundred yards upstream of the confluence with Gomanche Creek, which occurs near the center of a spectacular series of rapids and falls where both streams are deeply incised into the Michigamme Slate. Arvon Road crosses Silver River on a high-capacity modern concrete bridge demonstrative of the importance of the forestproducts industry in this remote location. The reach upstream and downstream of the bridge is high-gradient and composed of numerous riffles of rocks and boulders (fig. 8). During periods of low streamflow, the area immediately downstream of the bridge is pooled behind a riffle, but the channel bottom and banks are strewn with boulders that make water-quality sampling and streamflow measuring difficult. During moderate flows, a number of the pools are suitable for water-quality sampling, although useable streamflow-measuring sections are less plentiful. During times of high runoff, sampling is difficult at this site and streamflow measurement is impossible without incurring equipment damage. 


\section{Upper Gomanche Creek at Indian Road}

The drainage basin of upper Gomanche Creek at Indian Road (site 04043135) includes an area of about $0.9 \mathrm{mi}^{2}$ (fig. 2). Gomanche Creek flows through a steel culvert under Indian Road at this site. Upstream of the road, the deeply incised channel typically is less than 6-ft wide and consists of a series of riffles and pools flowing through a cedar forest (fig. 9). A number of the pools are suitable for water-quality sampling, although good quality streamflow-measuring sections are less plentiful. This part of Gomanche Creek drains the south side, and perhaps part of the west side, of the bedrock high comprising the BIC.

\section{East Branch Tributary to Gomanche Creek at Indian Road}

The East Branch Tributary to Gomanche Creek at Indian Road (site 04043137) drains an area of $0.2 \mathrm{mi}^{2}$ (fig. 2).

The East Branch Tributary flows through a steel culvert under Indian Road at this site. Upstream of the road, the deeply incised channel typically is less than 3 - $\mathrm{ft}$ wide and consists of a series of riffles and pools (fig. 10). Several of the pools are suitable for water-quality sampling, although good-quality streamflow-measuring sections are nonexistent. The stream originates in wetlands located on the northeast side of the bedrock high comprising the BIC. The stream is not shown on topographic maps until it crosses an abandoned logging railroad grade about 0.5 -mi downstream of the wetland; however, it was found to be flowing downstream of the wetland when it was checked during the study period. The stream appears to drain the north and east sides of the bedrock high.

\section{West Branch Tributary to Gomanche Creek}

The West Branch Tributary to Gomanche Creek (USGS site 04043138 ) drains an area of about $0.3 \mathrm{mi}^{2}$ and is located about 0.25 -mi west of site 04043137 (fig. 2). The sampling location is located upstream of a steel culvert where the West Branch Tributary flows under an unnamed logging road about 0.25-mi west of Indian Road. Parts of this stream are incorrectly shown on topographic maps, as is the East Branch Tributary. Unfortunately, it appears that remote-sensing techniques used to produce topographic maps have resulted in logging roads near these two streams being illustrated as streams, and conversely, streams illustrated as logging roads. The wetland where the west tributary appears to originate is located west of Indian Road, and west northwest of the bedrock high comprising BIC, but the stream follows a different route than the one illustrated on topographic maps from there to the sampling site and then downstream for a few hundred more yards. This stream appears to drain part of the northwest side of the bedrock high.
Upstream from the road crossing, the channel typically is less than 3-ft wide and consists of a series of riffles and pools, which are suitable for water-quality sampling (fig. 11) but poor for measuring streamflow during much of the year. The reach 75 to 150 -ft downstream of the logging-road crossing has the highest-quality streamflow-measuring sections. A container of known volume (1-gal plastic pail) and stopwatch were used to accurately measure streamflow during low-flow periods, because appreciable fall exists on the downstream end of the culvert.

\section{Gomanche Creek at Indian Road}

Gomanche Creek at Indian Road drains an area of $3.5 \mathrm{mi}^{2}$ (fig. 2). The precast-concrete culvert-style bridge at the site was installed after the previous bridge was washed out on May 12, 2003, when a dam at Lost Lake (shown on fig. 2 as KBIC sampling site LL1-MS) failed during a localized, multiinch rainfall event (fig. 12). The same storm system moved east, washing out two dams in the Dead River Watershed in Marquette County, resulting in appreciable property and environmental damage. The channel at the downstream side of the bridge is straight for about $75 \mathrm{ft}$, and conditions for waterquality sampling and streamflow measurements are good during typical streamflows. A continuous-record streamflow gage and water-quality monitor to measure water temperature and specific conductance (streamgage 04043140) were installed upstream of the culvert and made operational October 31, 2007 (fig. 13).

Annual mean streamflow for 2008 was $4.8 \mathrm{ft}^{3} / \mathrm{s}$, or $1.05\left(\mathrm{ft}^{3} / \mathrm{s}\right) / \mathrm{mi}^{2}$ of drainage area. Mean annual runoff for 2008 was 14.32 in.

\section{Dakota Creek at Trail Crossing}

Dakota Creek at Trail Crossing (site 04043146) drains an area of about $8.4 \mathrm{mi}^{2}$, flowing across an unnamed logging road about 3.7-mi northeast of site 04043131 (fig. 2). Bedrock is mapped as being close to the surface throughout much of the Dakota Creek Watershed (Doonan and Byerlay, 1973) but no outcrops were apparent near the sampling site, where the channel typically is sand and gravel with a series of cobble/boulder riffles. A number of good water-quality sampling sites and streamflow-measuring sections are available within several hundred feet of the trail crossing (fig. 14).

\section{Silver River near L'Anse}

The Silver River near L'Anse streamgage (04043150) is located on Skanee Road about 8-mi northeast of L'Anse and about 1-mi upstream of the mouth at Huron Bay (fig. 2).

The drainage basin of the Silver River at L'Anse encompasses an area of $64.7 \mathrm{mi}^{2}$ (about $69 \mathrm{mi}^{2}$ at the mouth). A continuousrecord streamgage has been operating at the site since 
October 2001. A water-temperature sensor was installed in May 2002 and operated until October 2005 when it was replaced by a multiparameter probe measuring specific conductance and water temperature. Water-quality samples and streamflow measurements are obtained at the site by either wading or using a bridge crane and suspended D-95 sampler or current meter off the bridge. Conditions for sampling and measuring are good at all stages. Annual mean streamflow for the period $2002-08$ is $82.9 \mathrm{ft}^{3} / \mathrm{s}$ or $1.3\left(\mathrm{ft}^{3} / \mathrm{s}\right) / \mathrm{mi}^{2}$ of drainage area. Mean annual runoff for the period $2002-08$ is $17.3 \mathrm{in}$.
Water year 2008 was somewhat wetter than other years with annual runoff of $1.5\left(\mathrm{ft}^{3} / \mathrm{s}\right) / \mathrm{mi}^{2}$ of drainage area or $20.4 \mathrm{in}$. for the year. Highest streamflow for the period of record at the site is $3,180 \mathrm{ft}^{3} / \mathrm{s}$, which occurred May 12, 2003, after the dam at Lost Lake (located in the Gomanche Creek Watershed) failed during an extremely heavy, localized rainfall event. Stream stage has been higher than the underside of the bridge twice since the gage became operational. Lowest streamflow for period of record at the site is $3.5 \mathrm{ft}^{3} / \mathrm{s}$, which occurred several days in mid-August 2007; lowest streamflow during 2008 was $7 \mathrm{ft}^{3} / \mathrm{s}$.
Figure 6. U.S. Geological Survey hydrologic technician examining low-water control downstream of bridge at USGS streamgage 04043126 prior to ecological sampling. (Photograph by J.A. Wilkinson, U.S. Geological Survey)

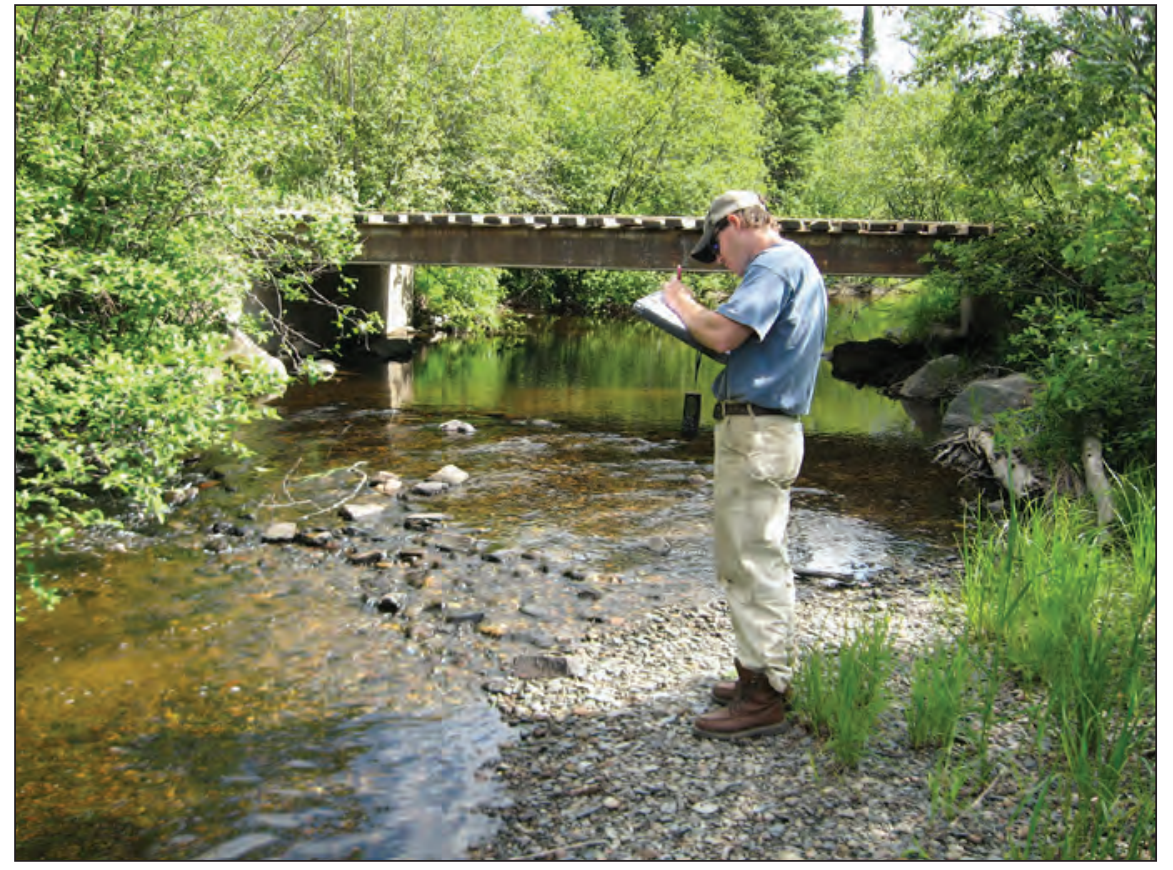

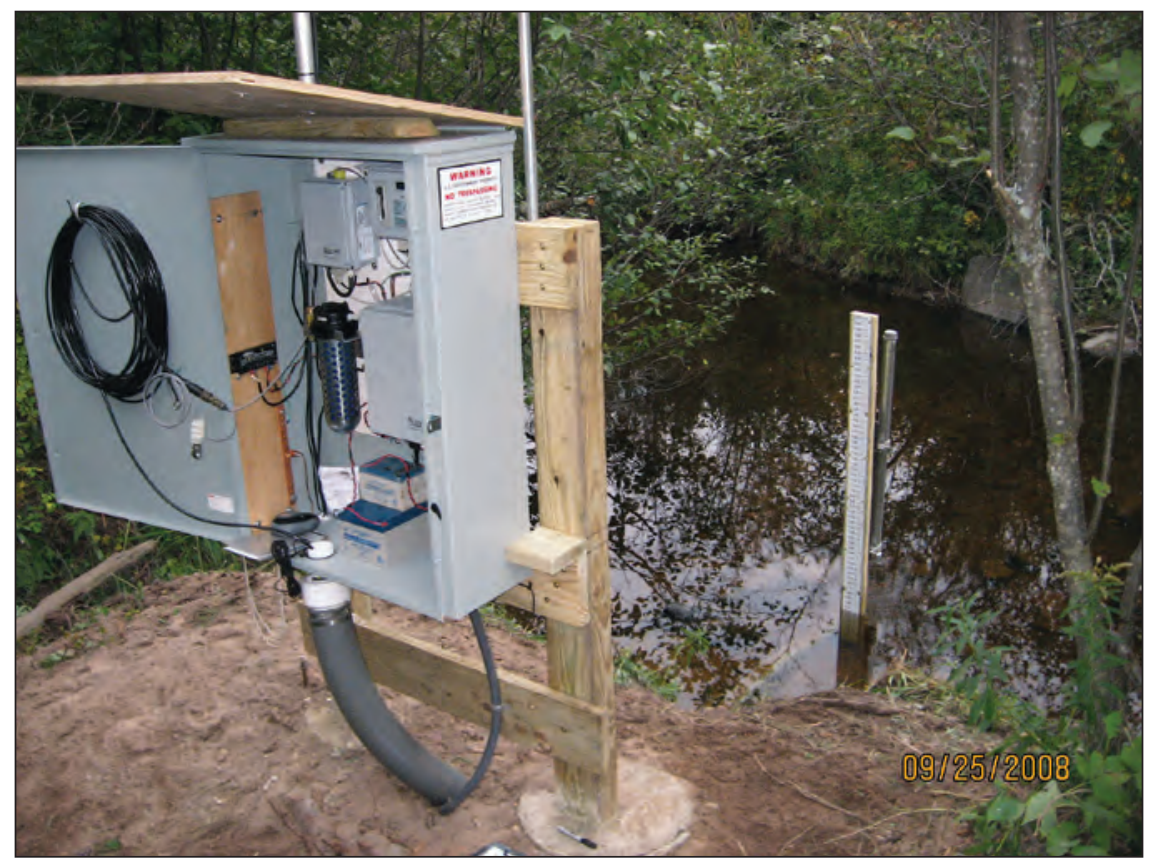

Figure 7. U.S. Geological Survey streamgage at upper Silver River (04043126) during installation. (Photograph by M. A.A. Holmio, U.S. Geological Survey) 


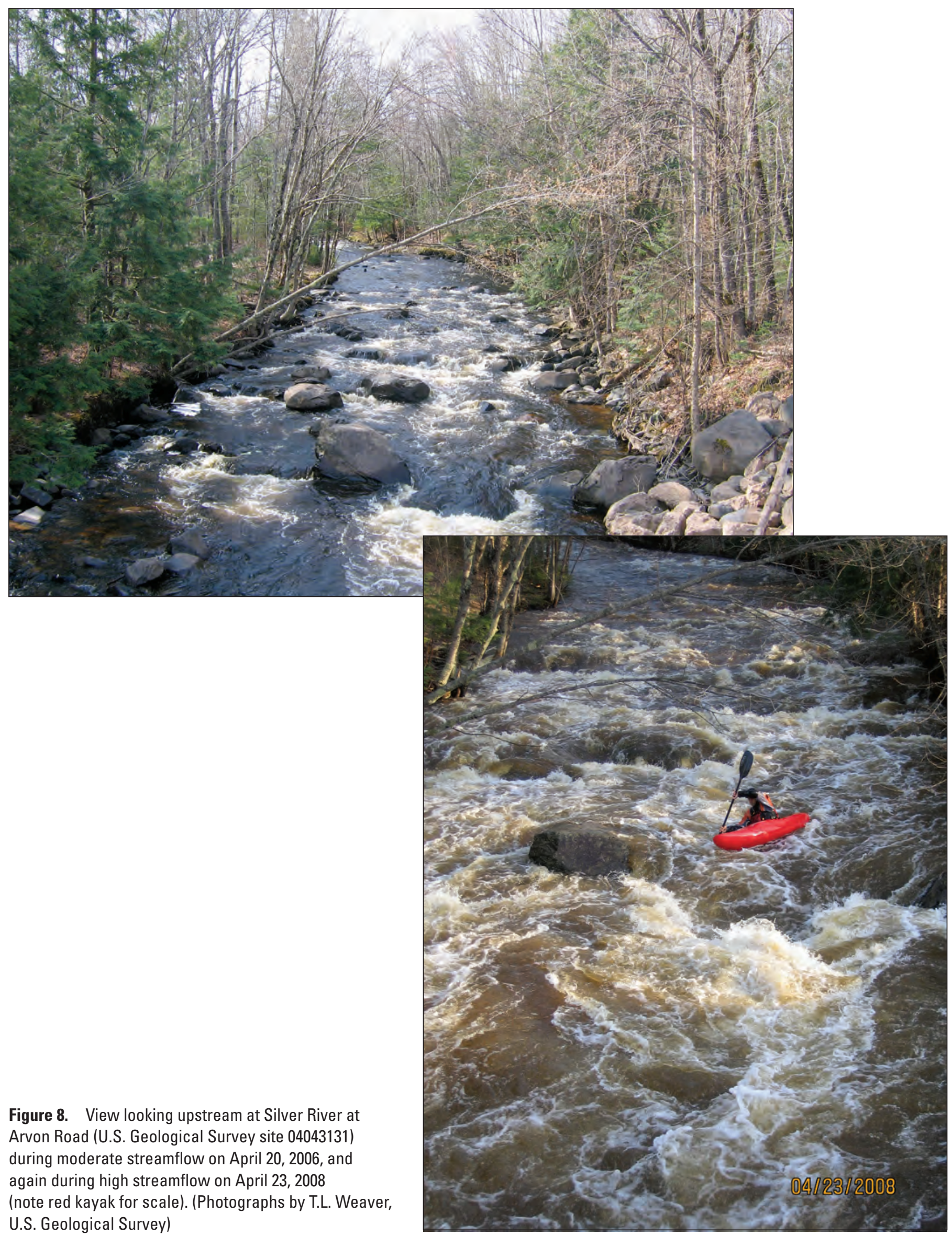


Figure 9. View looking upstream at upper Gomanche Creek at Indian Road (U.S. Geological Survey site 04043135) from Indian Road, May 10, 2005.

(Photograph by T.L. Weaver, U.S. Geological Survey)
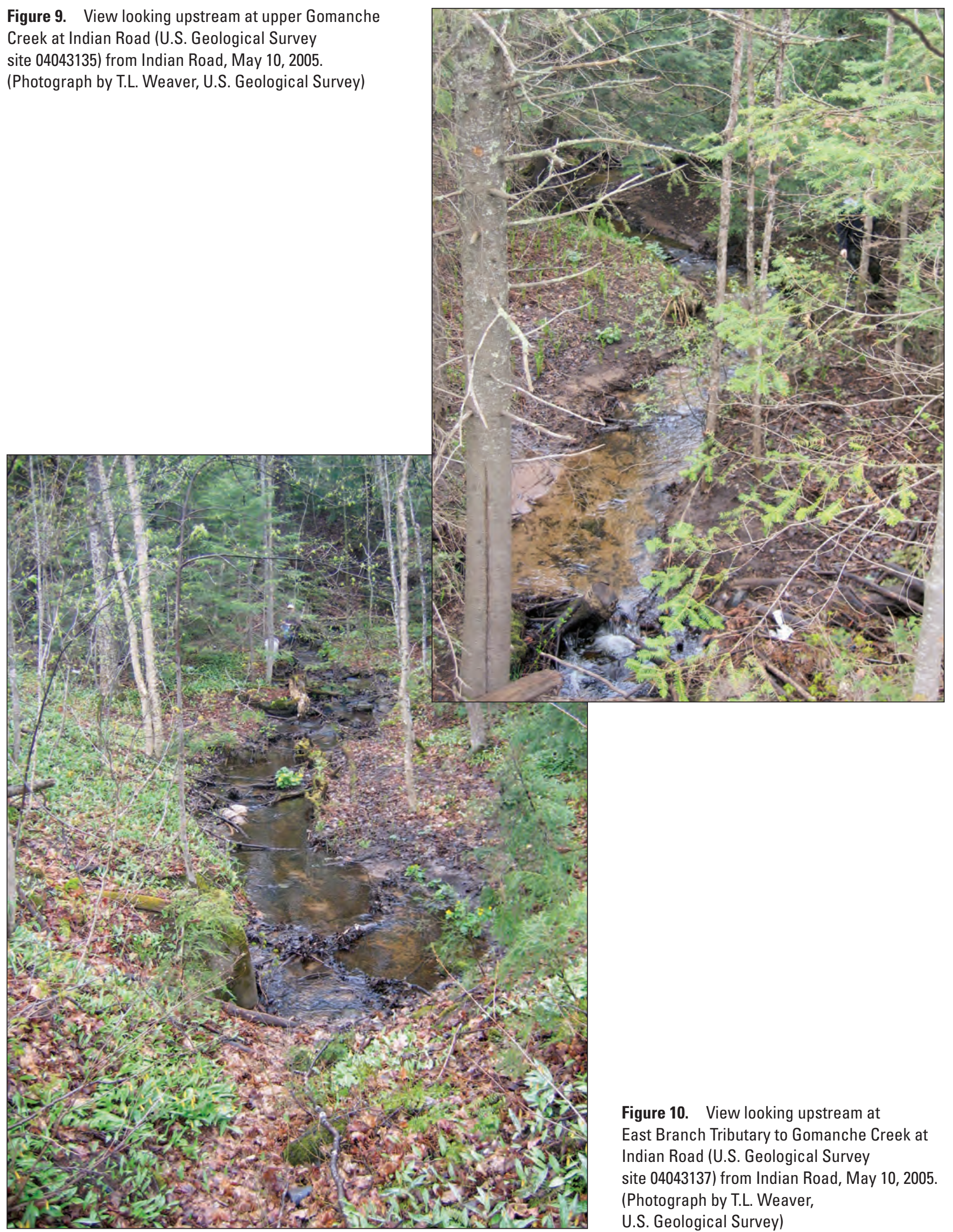

Figure 10. View looking upstream at East Branch Tributary to Gomanche Creek at Indian Road (U.S. Geological Survey site 04043137) from Indian Road, May 10, 2005. (Photograph by T.L. Weaver, U.S. Geological Survey) 


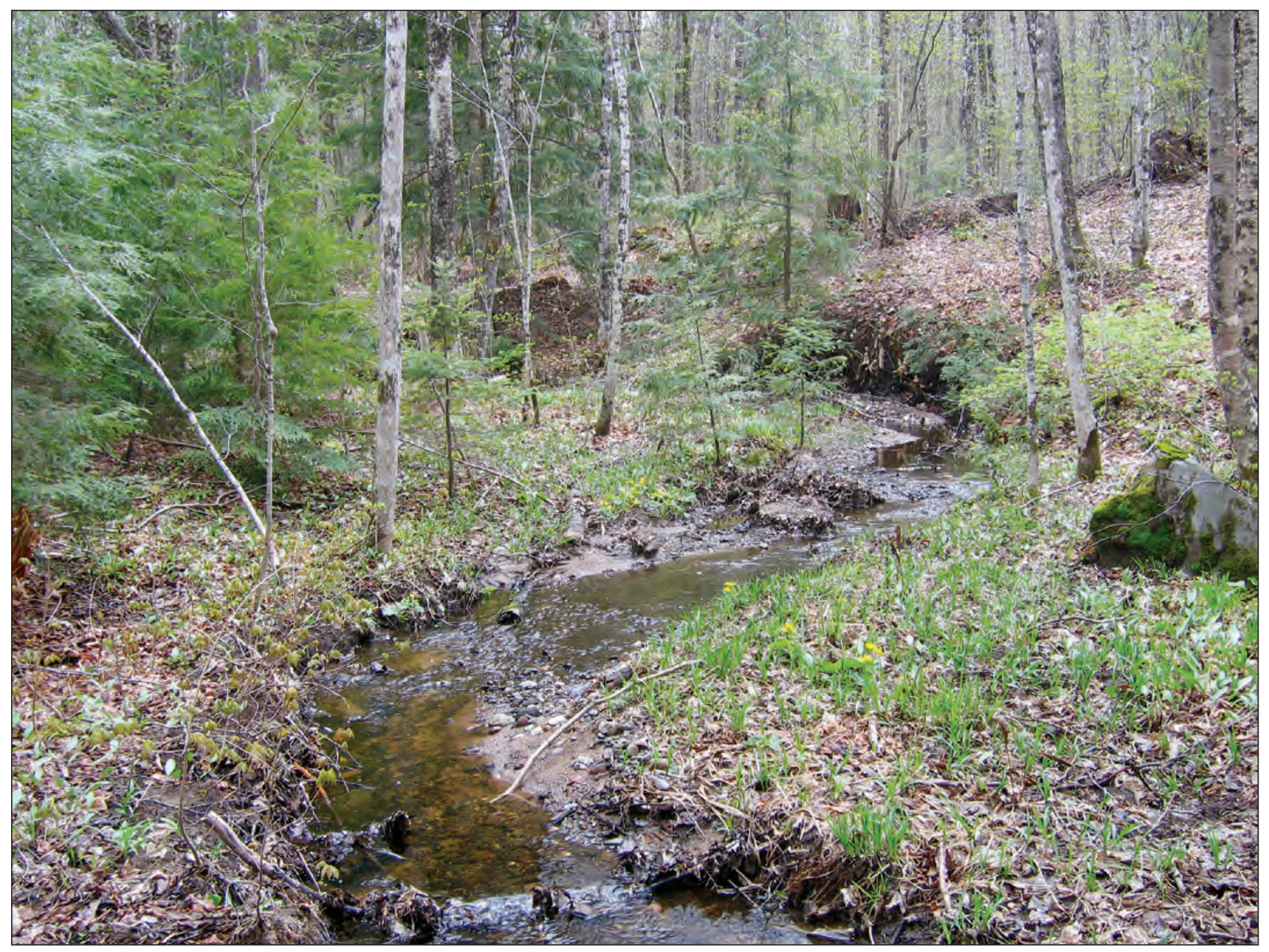

Figure 11. View looking upstream at West Branch Tributary to Gomanche Creek (U.S. Geological Survey site 04043138) from unnamed logging road, May 11, 2005. (Photograph by T.L. Weaver, U.S. Geological Survey)

Figure 12. View looking upstream at a concrete culvert at the Indian Road crossing of Gomanche Creek (U.S. Geological Survey streamgage 04043140), May 11, 2005. (Photograph by T.L. Weaver U.S. Geological Survey)

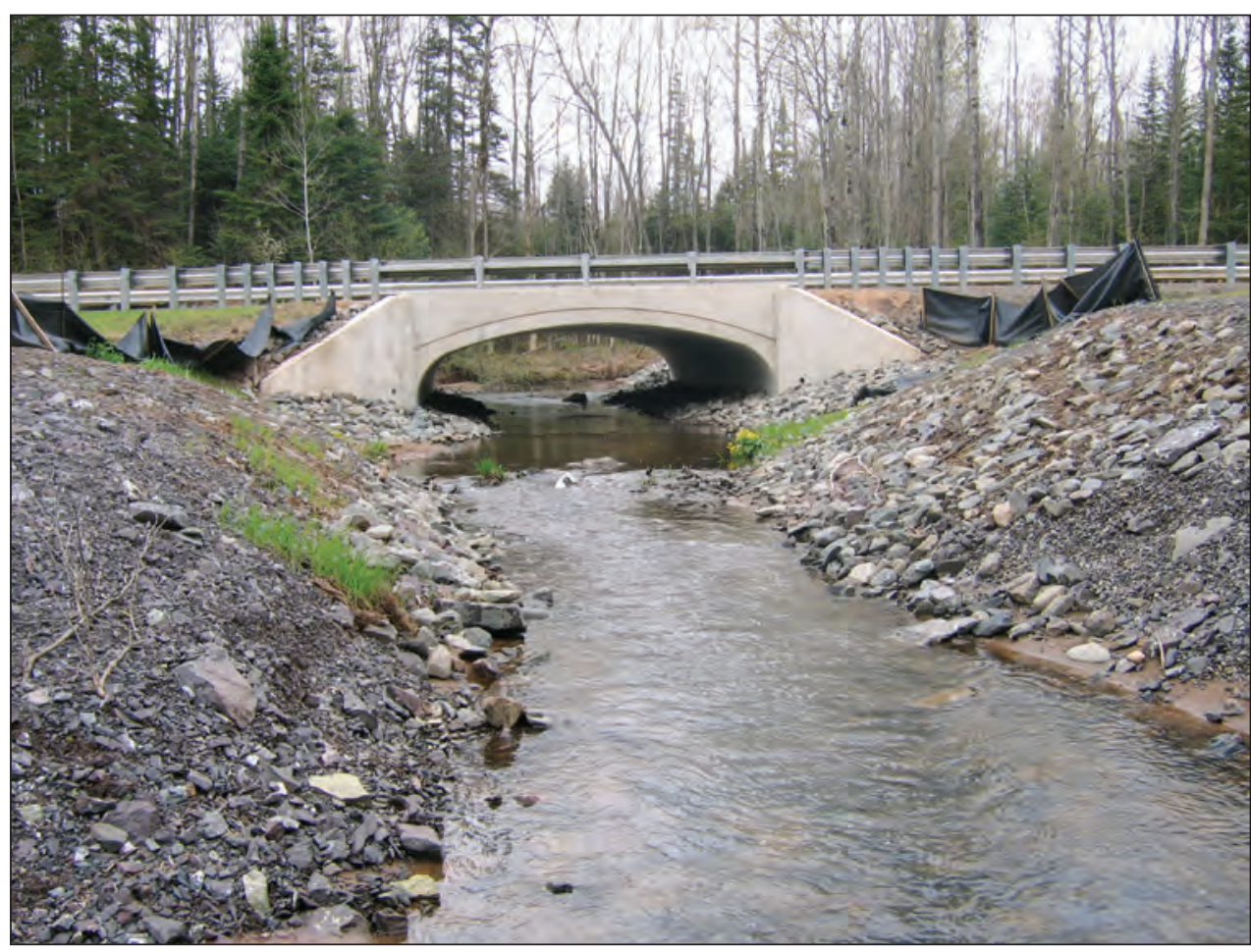




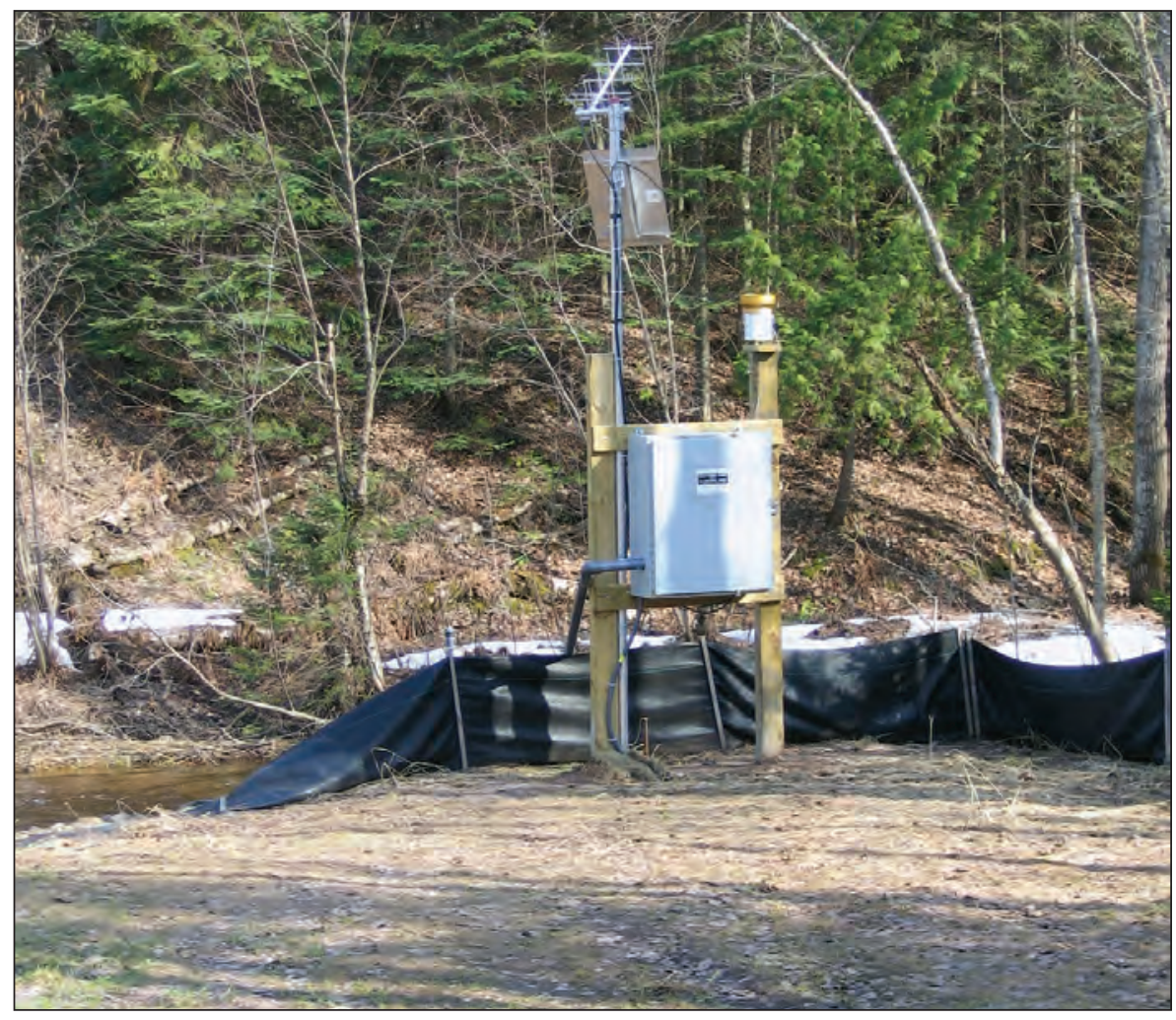

Figure 13. U.S. Geological Survey streamage at Gomanche Creek at Indian Road (04043140). (Photograph by T.L. Weaver, U.S. Geological Survey)

Figure 14. Dakota Creek at unnamed logging-road crossing (U.S. Geological Survey site 04043146), May 12, 2005. (Photograph by T.L. Weaver, U.S. Geological Survey)

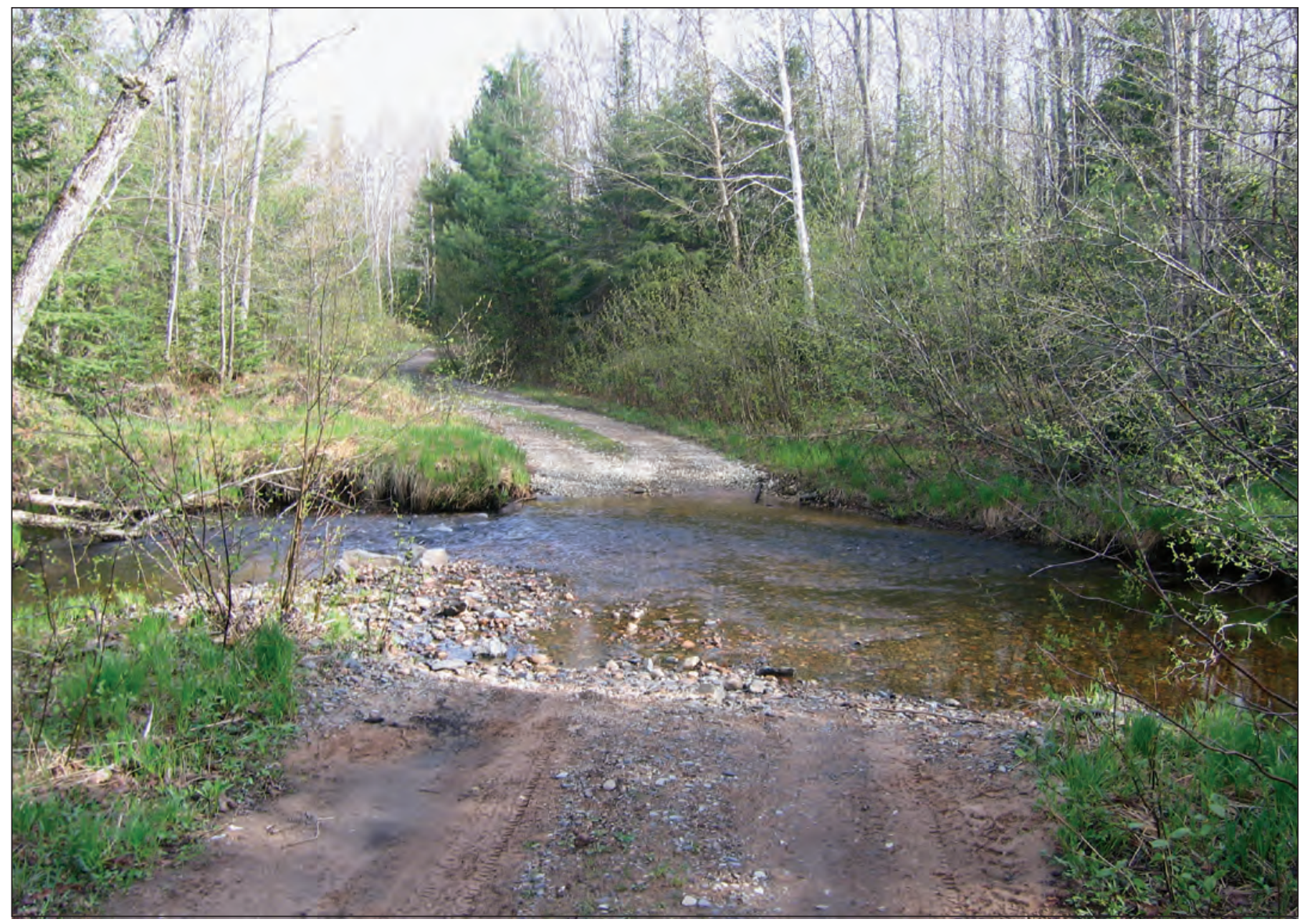




\section{Water Quality of Streams in the Silver River Watershed}

Factors that affect water quality of a stream are complex and interrelated. Geological and geomorphic characteristics of the watershed, as well as hydrological and biological components of the ecosystem, all affect the water chemistry.

The tributaries to the Silver River drain a geomorphically diverse watershed (figs. 4 and 5). Water-quality samples were collected 10 times at eight locations during the period May 2005-April 2008. An additional set of samples was collected in September 2008 for mercury analysis only. The database developed from this study provides useful information to enhance future stream-monitoring, data-collection, and interpretive efforts.

\section{Field Water-Quality Parameters, Major lons, Alkalinity, Nutrients, Metals, and Cyanide}

A summary of sampling periods and USGS NWQL lab codes and schedules used for this study are provided in table 6 . Streamflow, field water-quality parameters, major ions, suspended solids, nutrients, metals, and cyanide are summarized in appendix 1.

\section{Field Water-Quality Parameters, Major lons, and Alkalinity}

Water samples from streams in the Silver River Watershed ranged from 6.7 to 8.5 for $\mathrm{pH}$ and 23 to $270 \mu \mathrm{s} / \mathrm{cm}$ for specific conductance (the lowest $\mathrm{pH}$ and conductance typically, but not exclusively, was measured during spring sampling). Concentrations of chloride ranged from an estimated 0.11 to $1.67 \mathrm{mg} / \mathrm{L}$, indicating little effect from septic systems or road-deicing salt. By comparison, Weaver and Fuller (2007) noted a maximum concentration of chloride of $270 \mathrm{mg} / \mathrm{L}$ in 141 measurements made at the Clinton River in Mt. Clemens in Lower Michigan from 1973 to 1995 . Water samples can be classified as soft, medium, and hard (Hem, 1985, p. 159), with concentrations of hardness reported as calcium carbonate ranging from 12 to $130 \mathrm{mg} / \mathrm{L}$ (average hardness is about 55 $\mathrm{mg} / \mathrm{L}$, which is soft). Concentrations of calcium, magnesium, and other dissolved solids (residue on evaporation at $180^{\circ} \mathrm{C}$ ) ranged from 35 to $149 \mathrm{mg} / \mathrm{L}$ throughout the study area, with highest concentrations typically occurring within the Gomanche Creek Watershed. Alkalinity, which is a measure of the capacity to react with and to neutralize acid (Hem, 1985), enables prediction of how easily acid rain can affect water quality of a specific water body. Alkalinity, in most natural waters, is related to higher levels of dissolved carbon dioxide species (carbonate and bicarbonate). Alkalinity data from the Silver River Watershed are expressed in equivalent calcium carbonate units; alkalinity ranged from 5 to $126 \mathrm{mg} / \mathrm{L}$. The Silver River sites are considered moderate to non-sensitive to acid rain when compared to Wisconsin's alkalinity standards for surface-water bodies (Michigan currently (2009) does not have a standard for alkalinity of surface-water bodies) (table 7). Upstream parts of the watershed appear to be most susceptible, particularly during snowmelt/spring runoff, when alkalinity is lowest.

\section{Nutrients}

One indicator of the water quality of a stream is its biological productivity. Biological productivity may be altered from a stream's natural state when human activities cause an increase in nutrients. Levels of nutrients above a natural "baseline" most commonly result from the effects of septic systems or sewers and agricultural and domestic application of fertilizers. Sewage effluent is the largest single source of phosphorus in natural waters (Hem, 1985); however, the Silver River Watershed is sparsely populated with only a few homes near enough to the river to affect nutrient levels. Therefore, it

Table 6. U.S. Geological Survey National Water Quality Laboratory codes, schedules, and respective analytes used for sampling in the Silver River Watershed, Michigan, 2005-08.

[LC, lab code; NA, not applicable; ${ }^{\circ} \mathrm{C}$, degrees Celsius; $<$, less than]

\begin{tabular}{|c|c|c|}
\hline Sampling period & LC or schedule & Analyte \\
\hline $2005-08$ & Schedule 2701 & Major inorganics \\
\hline $2005-08$ & Schedule 2702 & Low-level nutrients \\
\hline $2005-08$ & Schedule 2044 & Trace elements \\
\hline 2005-October 2007 & NA & Cyanide \\
\hline 2005-July 2007 & LC 165 & $\begin{array}{l}\text { Residue on evaporation, } \\
\text { dried at } 105^{\circ} \mathrm{C}\end{array}$ \\
\hline 2005-July 2007 & LC 169 & $\begin{array}{l}\text { Residue on evaporation, } \\
\text { dried at } 180^{\circ} \mathrm{C}\end{array}$ \\
\hline September 2007-08 & NA & $\begin{array}{l}\text { Suspended sediment, } \\
\text { sieve diameter } \\
<0.063 \text { millimeters }\end{array}$ \\
\hline September 2007-08 & NA & $\begin{array}{l}\text { Suspended sediment, } \\
\text { concentration }\end{array}$ \\
\hline September 2008 & NA & Total mercury, unfiltered \\
\hline September 2008 & NA & $\begin{array}{l}\text { Methylmercury, } \\
\text { unfiltered }\end{array}$ \\
\hline
\end{tabular}

Table 7. Sensitivity of surface-water bodies to acid rain; guidelines for Wisconsin (Wisconsin Department of Natural Resources, 2004).

[Alkalinity is in units of milligrams per liter as calcium carbonate $(\mathrm{CaCO} 3) ;>$, greater than]

\begin{tabular}{lc}
\hline \multicolumn{1}{c}{ Sensitivity } & Alkalinity \\
\hline High & $0-2$ \\
Moderate & $>2-10$ \\
Low & $>10-25$ \\
Nonsensitive & $>25$ \\
\hline
\end{tabular}


is reasonable to assume that nutrient levels measured during this study are representative of non-perturbed or natural "baseline" conditions.

Laboratory analyses showed concentrations of ammonia plus organic nitrogen in unfiltered water ranging from an estimated 0.06 to $0.52 \mathrm{mg} / \mathrm{L}$ at all sites except East Branch Tributary to Gomanche Creek site (04043137), which had concentrations ranging from 0.41 to $0.65 \mathrm{mg} / \mathrm{L}$. Concentrations of nitrate plus nitrite in filtered water ranged from 0.02 to 0.23 $\mathrm{mg} / \mathrm{L}$ at all sites except West Branch Tributary to Gomanche Creek (04043138), which had a concentration of $0.47 \mathrm{mg} / \mathrm{L}$ on October 31, 2007. Concentrations of total phosphorus in unfiltered water ranged from an estimated value of 0.004 to $0.05 \mathrm{mg} / \mathrm{L}$ at all sampling sites except 04043137 , which had concentrations that were all less than $0.01 \mathrm{mg} / \mathrm{L}(0.013$ to $0.086 \mathrm{mg} / \mathrm{L}$ ). Concentrations of nutrients in the Silver River Watershed are low, indicating little, if any, septic-system or agricultural-waste effect in the watershed during the time of this study.

\section{Nickel and Copper}

Concentrations of nickel ranged from 0.1 to $1.57 \mu \mathrm{g} / \mathrm{L}$, with the highest concentrations found in samples from the upper Silver River, East Branch Tributary to Gomanche Creek, and downstream Gomanche Creek sites. Concentrations of copper ranged from an estimated value of 0.26 to $22.9 \mu \mathrm{g} / \mathrm{L}$, with the highest concentrations found in samples from the upper Silver River (22.9 $\mu \mathrm{g} / \mathrm{L})$ and Dakota Creek $(16.3 \mu \mathrm{g} / \mathrm{L})$. There appears to be a correlation between high concentrations of copper and high streamflows at the other six sites, but this was not the case at the two sites with the highest concentrations. Erosion and runoff also are highest during periods of high streamflow; however, both high-concentration samples were collected during a period of low streamflow in September 2006. One possible scenario is that the streams are in direct contact with copper-bearing geologic materials upstream of the two sites with the highest concentrations. Seven samples had concentrations of copper that exceeded the MDEQRule 57 water-quality standard aquatic-maximum value of $7.6 \mu \mathrm{g} / \mathrm{L}$ (Michigan Department of Environmental Quality, 2008), including three samples from the East Branch Tributary to Gomanche Creek site (04043137).

\section{Mercury}

Some streams and lakes in northern Baraga and Marquette Counties are known to have elevated concentrations of mercury in game fish, but the source of the mercury is unknown. The Michigamme Slate is known to be locally anomalously enriched in $\mathrm{Hg}$ with vales as high as 1.6 parts per million (ppm). Likewise, mineral prospectors have reported cinnabar from time to time. Atmospheric deposition of mercury is probably the dominant source of mercury to the Silver River Watershed although some concealed bedrock sources may also be in contact with parts of the streams. (W.F. Cannon, U.S. Geological Survey, written commun., 2009)

Investigations initiated in the late 1980s in the northern-tier states of the U.S., Canada, and Nordic countries found that fish, mainly from nutrient-poor lakes and often in very remote areas, commonly have high levels of mercury. More recent fish-sampling surveys in other regions of the U.S. have shown widespread mercury contamination in streams, wetlands, reservoirs, and lakes. To date (2009), 33 states have issued fish-consumption advisories because of mercury contamination (Krabbenhoft and Rickert, 1995). (See inset box on page 22.)

The USGS Wisconsin Water Science Center houses the Mercury Research Laboratory (USGS MRL) and team. Prior to September 2008, samples from the Silver River Watershed sites were analyzed using the mercury-analytical schedule at the USGS NWQL. The September 2008 samples were analyzed using the USGS MRL protocol and laboratory. All sites were sampled for unfiltered total mercury and methylmercury, and those results are summarized in table 8. Unfiltered samples contain both dissolved and particulate forms of mercury.

Table 8. Concentrations of total mercury and methylmercury in unfiltered water samples from the Silver River Watershed, Michigan.

[USGS, U.S. Geological Survey; SW, surface water; --, measurement not recorded; QA, quality-assurance sample; all concentrations are in nanograms per liter]

\begin{tabular}{|c|c|c|c|c|c|}
\hline USGS station number & Parameter & $\begin{array}{l}\text { Concentration } \\
\text { of unfiltered } \\
\text { total mercury }\end{array}$ & $\begin{array}{l}\text { Concentration } \\
\text { of unfiltered } \\
\text { methylmercury }\end{array}$ & $\begin{array}{c}\text { pH, in standard } \\
\text { units }\end{array}$ & $\begin{array}{l}\text { Ratio of } \\
\text { methylmercury } \\
\text { to total mercury }\end{array}$ \\
\hline 4043126 & SW & 3.44 & 0.38 & 7.5 & 0.11 \\
\hline 4043131 & SW & 2.74 & .33 & 7.9 & .12 \\
\hline 4043135 & SW & 4.52 & .24 & 8.1 & .05 \\
\hline 4043137 & SW & 5.48 & .25 & 7.9 & .05 \\
\hline 4043138 & SW & 2.43 & .28 & 8.6 & .12 \\
\hline 4043140 & SW & 1.31 & .18 & -- & .14 \\
\hline 04043146 & SW & 1.84 & .20 & 8.1 & .11 \\
\hline 04043146 & QA & $<.04$ & $<.04$ & 8.1 & -- \\
\hline 04043150 & SW & 2.43 & .28 & 7.7 & .12 \\
\hline
\end{tabular}


Mercury Cycling in Aquatic Systems

The following discussion of mercury in the environment largely is excerpted from Krabbenhoft and Rickert (1995). This discussion is provided to explain the complexities of mercury in the environment. There are many sources of mercury in the environment, both natural and anthropogenic. Natural sources include volcanoes, natural mercury deposits, and volatilization from the ocean. The primary human-related sources include coal combustion, chlorine alkali processing, waste incineration, and metal processing. Best estimates to date (2009) indicate that human activities have about doubled or tripled the amount of mercury in the atmosphere, and the atmospheric burden is increasing by about 1.5 percent per year.

Mercury-cycling pathways in aquatic environments are very complex. The various forms of mercury can be converted from one to the next; most important is the conversion to methylmercury (CH3Hg+), which is the most toxic form. Ultimately, mercury ends up in sediments, in fish and wildlife, or back into the atmosphere (fig. 15).

With the exception of isolated cases of known point sources, the ultimate source of mercury to most aquatic ecosystems is deposition from the atmosphere, primarily associated with rainfall. Although atmospheric deposition contains the three principal forms of mercury, the majority is inorganic (Hg(II), ionic mercury). Once in surface water, mercury enters a complex cycle in which one form can be converted to another.
It can be brought to sediments by particles settling and then later released by diffusion or resuspension. It can enter the food chain, or it can be released back into the atmosphere by volatilization.

Concentrations of dissolved organic carbon (DOC) and pH have a strong effect on the ultimate fate of mercury in an ecosystem. Studies have shown that for the same species of fish taken from the same region, increasing the acidity of the water (decreasing $\mathrm{pH}$ ) and (or) the DOC content generally results in higher concentrations of mercury in fish. At the time this report was written, many scientists believe that higher acidity and DOC levels enhance the mobility of mercury in the environment, thus making it more likely to enter the food chain.

The exact mechanism(s) by which mercury enters the food chain largely remain unknown and probably vary among ecosystems. We do know, however, that certain bacteria play an important early role. Studies have shown that bacteria that process sulfate (SO4) in the environment take up mercury in its inorganic form and through metabolic processes convert it to methylmercury. The conversion of inorganic mercury to methylmercury is important for two reasons: (1) methylmercury is more toxic than inorganic mercury and (2) organisms require considerably longer time to eliminate methylmercury than inorganic mercury. At this point, the methylmercury-containing bacteria may be consumed by the next higher level in the food chain, or the bacteria may release methylmercury into the water where it can quickly adsorb to plankton, which also are consumed by the next level in the food chain.
The lowest concentration of total mercury was sampled at the downstream Gomanche Creek site streamgage (04043140), and the highest concentration was sampled at the East Branch Tributary to Gomanche Creek site (04043137). The lowest concentration of methylmercury also was sampled at streamgage 04043140 , and the highest concentration was sampled at the upstream Silver River streamgage (04043126). The highest ratio of methylmercury to total mercury was at site streamgage 04043140 . Although concentration of mercury in several of the sites is high, the ratio of methylmercury to total mercury is similar to the 5 to 10 percent found in most natural waters (M.E. Brigham, U.S. Geological Survey, written commun., 2009). Typically, watersheds with larger percentages of wetlands have a greater percentage of methylmercury. The National Wetlands Inventory Database (U.S. Fish and Wildlife Service, 1994) indicates that wetlands upstream of the sampling sites comprise about 16 to 38 percent of each subwatershed (table 4).

There is a Great Lakes Basin water-quality standard for total mercury in water of $1.8 \mathrm{ng} / \mathrm{L}$ to protect human health from consumption of aquatic organisms (U.S. Environmental
Protection Agency, 1995a) and $1.3 \mathrm{ng} / \mathrm{L}$ to protect wildlife health (U.S. Environmental Protection Agency, 1995b). All samples exceed both of those standards; however, it should be noted that these are single-point samples taken during a period of low streamflows. Additional samples over the range of streamflow and conditions would need to be collected to confirm the persistence of the contamination or the need for a health or fishing advisory.

\section{Cyanide}

Measured concentrations of cyanide ranging from 0.0024 to $0.0058 \mathrm{mg} / \mathrm{L}$ were detected at least once at all sites except the downstream Silver River streamgage (04043150), and several sites had multiple detections. All concentrations were less than the LRL $(0.010 \mathrm{mg} / \mathrm{L})$, and several were at or near the MDL of $0.0024 \mathrm{mg} / \mathrm{L}$. A sample collected on July 26, 2005, at the East Branch Gomanche Creek site (04043137) had a concentration of $0.0058 \mathrm{mg} / \mathrm{L}$, which exceeds the MDEQ Rule 57 water-quality standard final chronic value of $0.0052 \mathrm{mg} / \mathrm{L}$ (Michigan Department of Environmental Quality, 2008). 


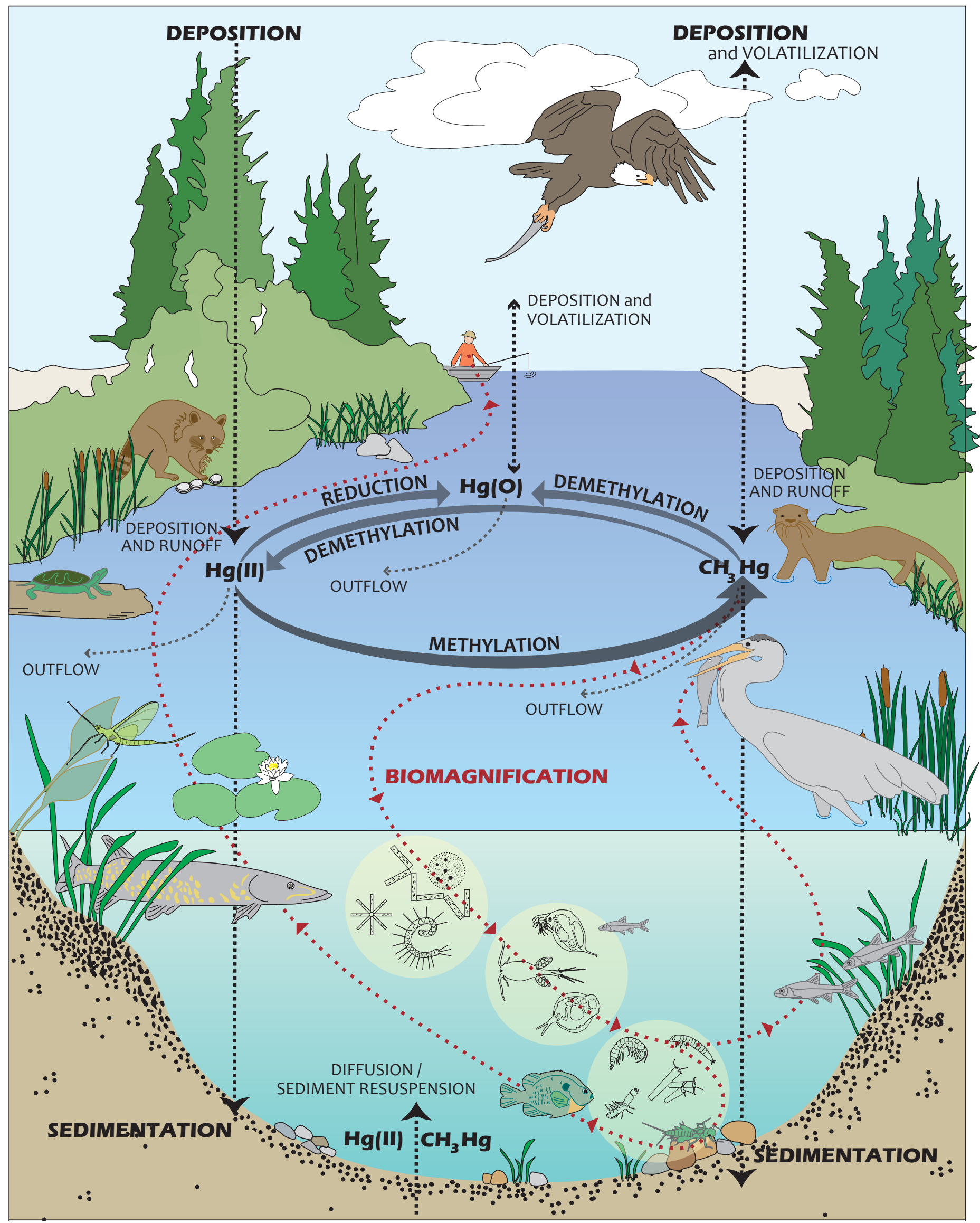

Figure 15. Aquatic mercury cycle illustrating the complexities of mercury-cycling pathways in aquatic environments. 


\section{The Elements of a Boxplot}

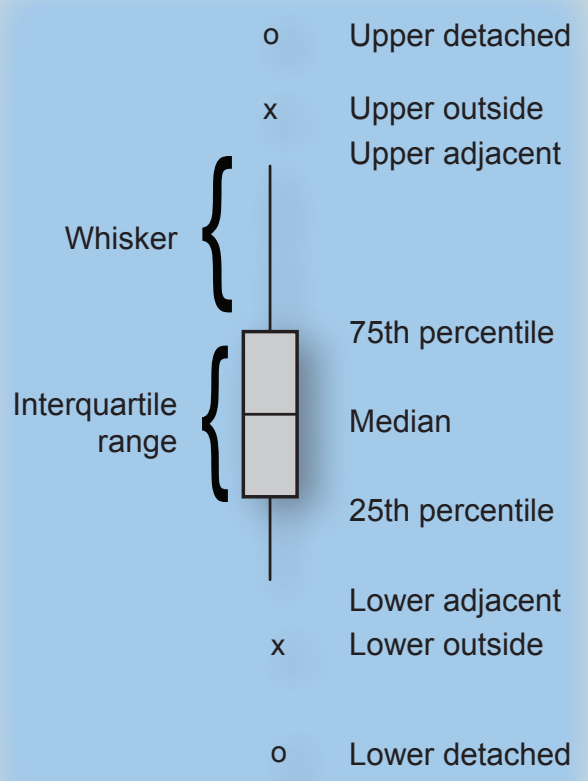

Boxplots provide a means to visualize the summary statistics of data. A quick glance at a boxplot would show the range in data values and whether the data are skewed. The main element of the boxplot is the box itself, whose top and bottom are defined by the 75th and 25th percentiles, respectively. The median (or 50 th percentile) typically is represented by a line that cuts across the box. The difference between the 75th and 25th percentiles is known as the Interquartile Range (IOR).

Lines extending up and down from the box are called whiskers, and their lengths are defined by the upper and lower adjacent values. The upper adjacent is equal to the maxiumum data value that is equal to or less than the 75 th percentile $+(1.5 \times 10 R)$; the lower adjacent is equal to the minimum data value that is is equal to or greater than the 25th percentile $-(1.5 \times$ IOR)

The upper outside value is outlier data whose value is greater than the upper adjacent value, but less than the 75th percentile $+2(1.5 \times$ IOR). The upper detached value is outlier data whose value is greater than this upper outside bounds.

The lower outside value is outlier data whose value is less than the lower adjacent value, but greater than the 25th percentile - 2 (1.5 x IOR). The lower detached value is outlier data whose value is even less thanthis lower outside bounds.

Boxplot statistics estimated below the largest laboratory method detection limit are represented by a dashed outline.

\section{Statistical Analysis of Water-Quality Data and Comparison to Water-Quality Guidelines}

Over the course of this study, laboratory methods changed as analytical equipment was replaced or updated, resulting in differing MDLs being used for sample analysis. This is important to note when employing the AMLE method for the calculation of summary statistics. Several of the analytes had detected and estimated concentrations present in enough samples for summary statistics to be calculated, even though most of the concentrations were below their respective detection limits. Summary statistics could not be calculated using the AMLE method for cyanide, mercury, and silver owing to each having an insufficient number of detected concentrations present in an adequate number of samples (appendix 1). Summary statistics of water-quality data collected as part of this study were calculated and graphed as boxplots. Although boxplots such as these appear complex, they convey a great deal of information succinctly (inset box page 24) (figs. 16-18). 

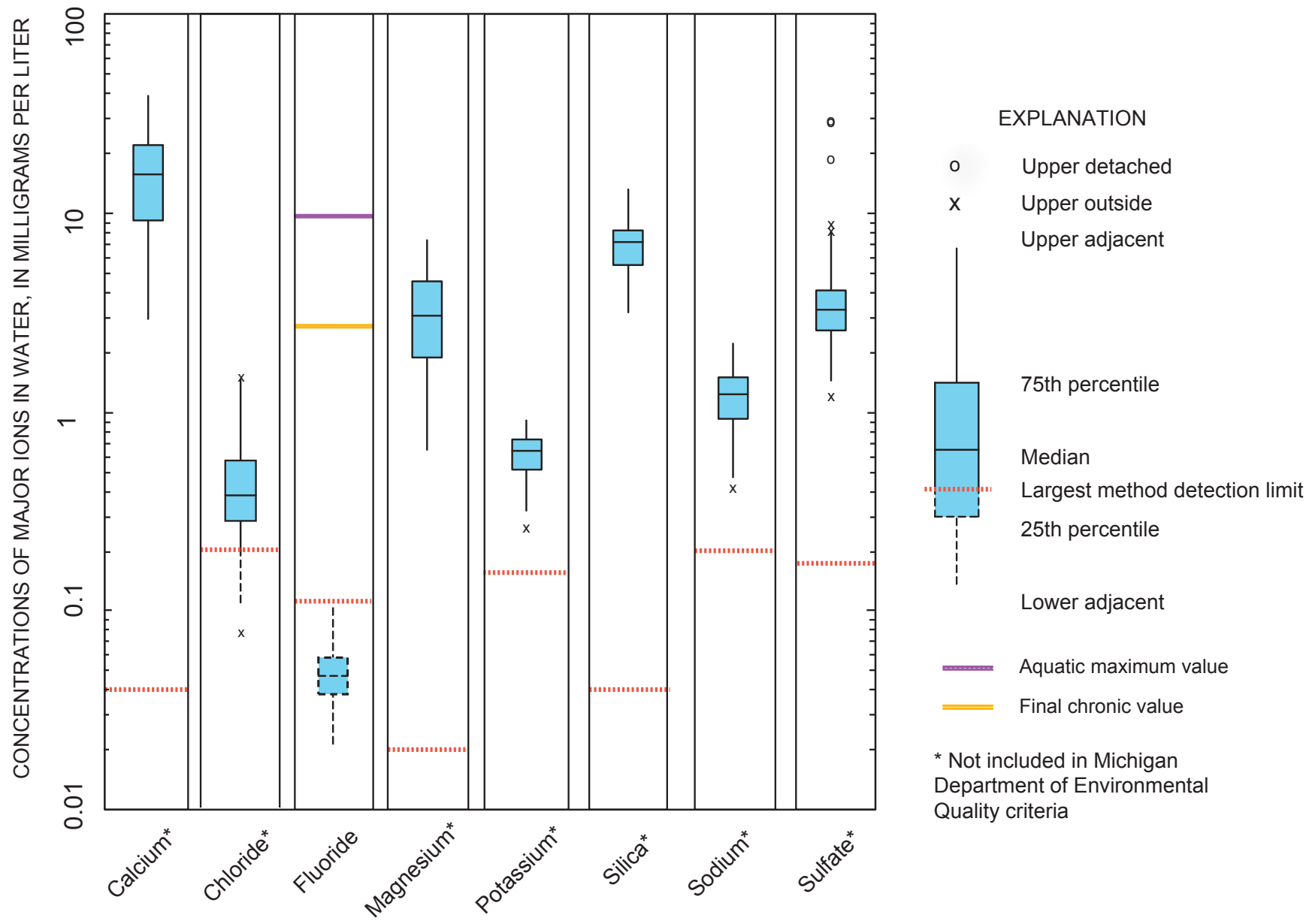

Figure 16. Concentrations of major ions in 80 water-quality samples, Silver River Watershed, Michigan, 2005-08 

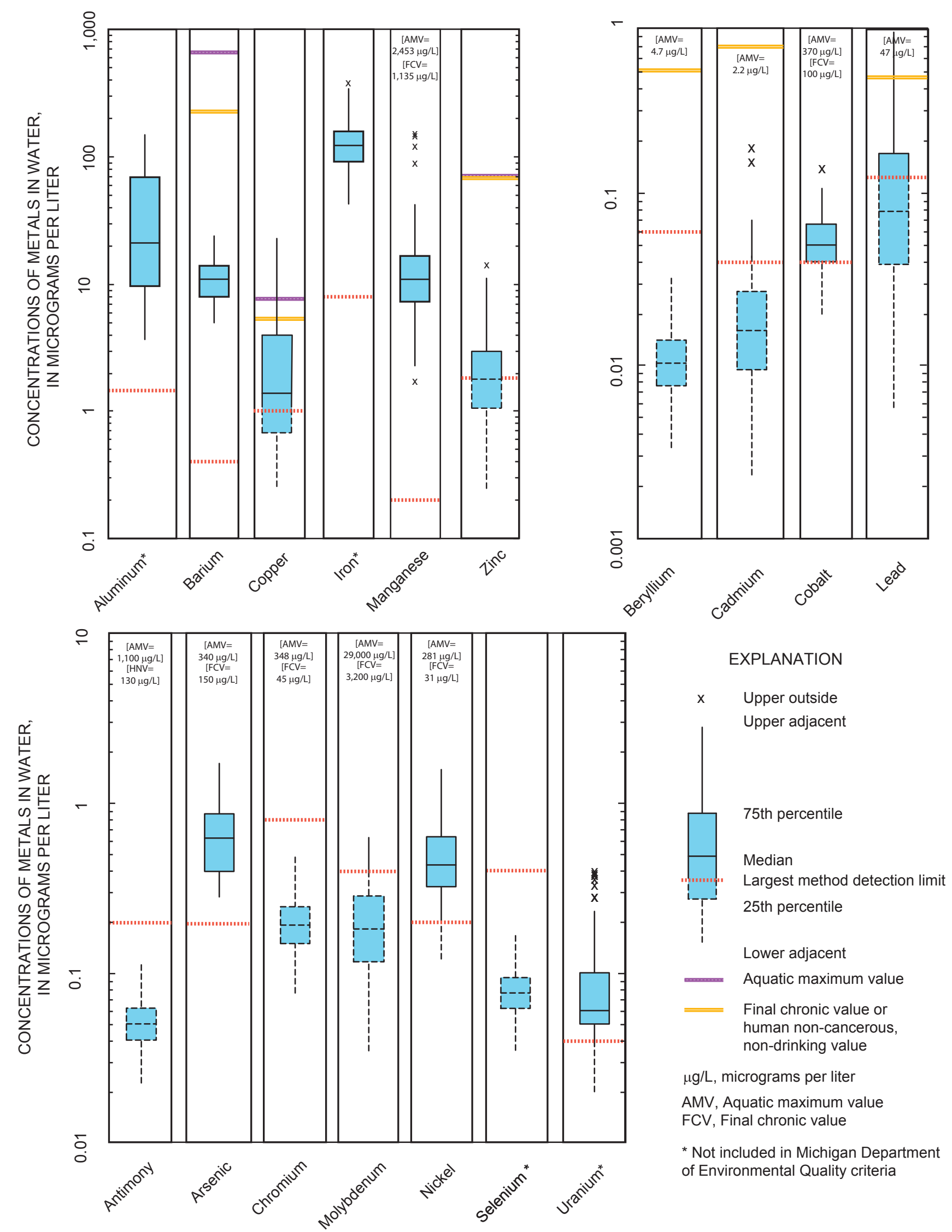

Figure 17. Concentrations of metals in 80 water-quality samples, Silver River Watershed, Michigan, 2005-08. 
A. FILTERED SAMPLES

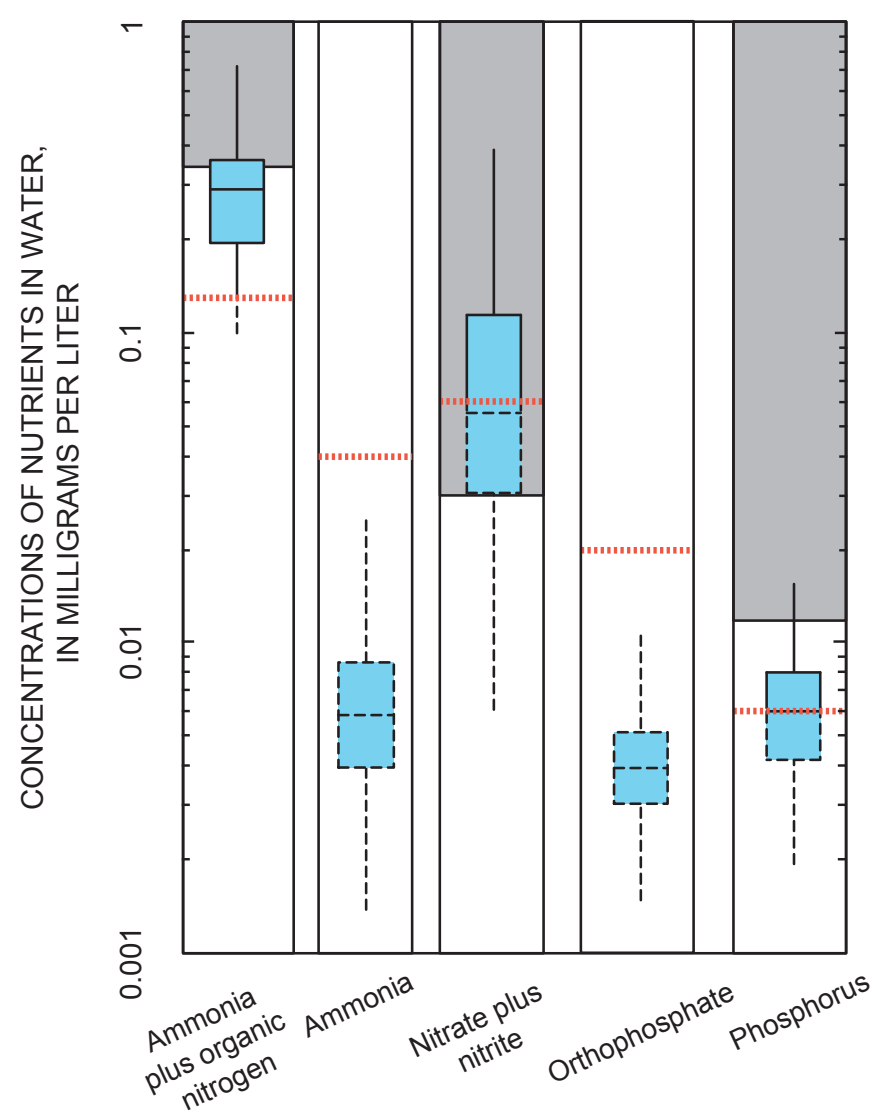

B. UNFILTERED SAMPLES

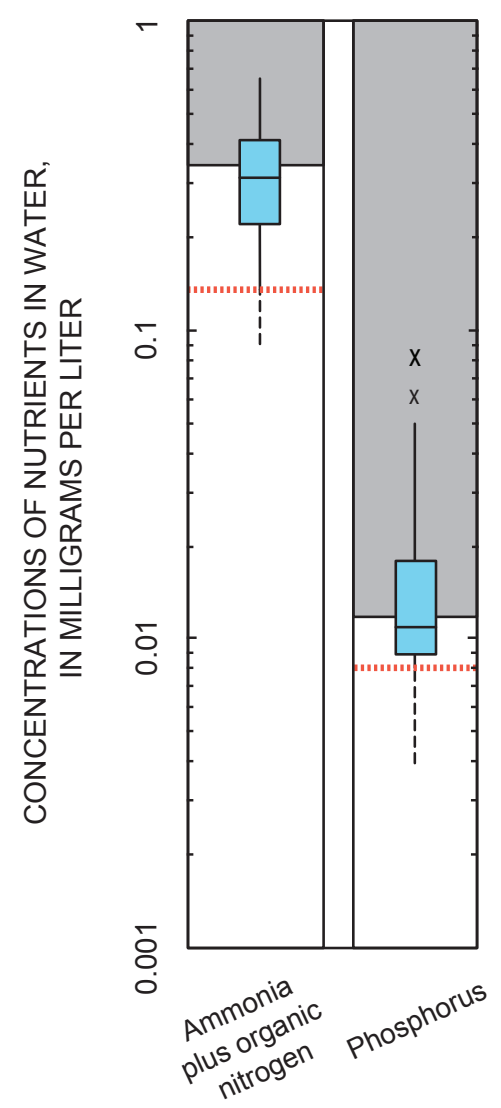

\section{EXPLANATION}

x Upper outside

Upper adjacent

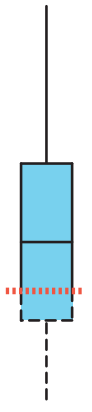

75th percentile

Median

25th percentile

Lower adjacent

nutrient concentration

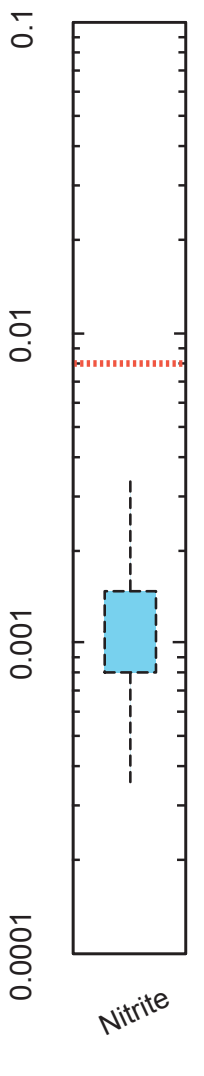

Largest method detection limit

25th percentile reference

from U.S. Environmental

Protection Agency (2001)

Figure 18. Concentrations of nutrients in 80 filtered $(A)$ and unfiltered (B) water-quality samples, Silver River Watershed, Michigan, 2005-08. 
In 2006, MDEQ adopted rules defining water-quality standards for the Great Lakes, connecting channels, and all other surface-water bodies in Michigan (Michigan Department of Environmental Quality, 2006a). The MDEQ rules provide selected water-quality criteria for cancerous and non-cancerous human consumption (drinking) and exposure (non-drinking), final chronic exposure, and wildlife and aquatic-ecosystem protection values (table 9). Although most of the Silver River Watershed is sparsely populated, a diverse population of wildlife and aquatic creatures lives within the watershed, and the Silver River drains into Huron Bay, itself a part of Lake Superior. KBIC is concerned that tribal members and others fishing, hunting, and living within the watershed are aware of any health concerns presented by surface-water quality degradation.

The human cancer value (HCV) is the maximum ambient-water concentration that a lifetime of direct exposure (either through consumption or from water-related recreation activities) or consumption of fish exposed to this concentration will represent a risk of contracting cancer of 1 in 100,000. The human non-cancerous value (HNV) represents the maximum ambient-water concentration at which adverse non-cancerous effects are not likely to occur from a lifetime of exposure through consumption or recreation activities or consumption of fish from these waters. The final chronic value (FCV) represents the concentration below which injurious or debilitating effects to an aquatic organism will not result after repeated long-term exposure. The wildlife value (WV) represents the maximum ambient-water concentration below which adverse effects are not likely to occur to mammal and bird populations through a lifetime exposure either through direct consumption or through exposure within their food supply (Michigan Department of Environmental Quality, 2006a).

For any given water-quality constituent, the recommended use of the criteria above involves selecting the most conservative value (lowest concentration) between the cancerous and non-cancerous human exposure and the WVs. Since the Silver River is not used as a water-supply source, it is not necessary to include the cancerous and non-cancerous humanconsumption criteria in this comparison. This conservative value is compared to the average concentration of the samples (Brenda Sayles, Michigan Department of Environmental Quality, oral commun., 2009).

The aquatic maximum value (AMV) represents the highest constituent concentration in ambient water that an aquatic community can briefly be exposed to without detriment (Michigan Department of Environmental Quality, 2006a). The AMV is compared to the maximum concentration of the samples (Brenda Sayles, Michigan Department of Environmental Quality, oral commun., 2009). HNVs, FCVs, and AMVs are listed for fluoride and all analyzed metals except aluminum, iron, selenium, and uranium. HCV and WV are not available for any of the analytes. All fluoride samples were well below the defined criteria (fig. 16). The AMV criteria for metals are dependent upon the calculated hardness of water, and an average hardness concentration of $54.8 \mathrm{mg} / \mathrm{L}$ was used for the calculations. Of the metal analytes, only copper exceeded the criteria; 13 of 80 copper samples exceeded the FCV and 7 of those exceeded the AMV as well (appendix 1, table 9, fig. 17).

Table 9. Human non-cancerous, final chronic, and aquatic-maximum criteria values for select constituents as defined by the Michigan Department of Environmental Quality (Michigan Department of Environmental Quality, 2006b).

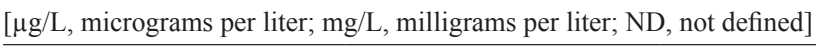

\begin{tabular}{lccc}
\hline \multicolumn{1}{c}{ Constituent } & $\begin{array}{c}\text { Human } \\
\text { non-cancerous value }\end{array}$ & Final chronic value & $\begin{array}{c}\text { Aquatic maximum } \\
\text { criteria value }\end{array}$ \\
\hline Antimony $(\mu \mathrm{g} / \mathrm{L})$ & 130 & 240 & 1,100 \\
Arsenic $(\mu \mathrm{g} / \mathrm{L})$ & 280 & 150 & 340 \\
Barium $(\mu \mathrm{g} / \mathrm{L})$ & 160,000 & 231 & 659 \\
Beryllium $(\mu \mathrm{g} / \mathrm{L})$ & 1,200 & .52 & 4.7 \\
Cadmium $(\mu \mathrm{g} / \mathrm{L})$ & 130 & .80 & 2.2 \\
Chromium $(\mu \mathrm{g} / \mathrm{L})$ & 9,400 & 45 & 348 \\
Cobalt $(\mu \mathrm{g} / \mathrm{L})$ & $\mathrm{ND}$ & 100 & 370 \\
Copper $(\mu \mathrm{g} / \mathrm{L})$ & 38,000 & 5.4 & 7.6 \\
Fluoride $(\mathrm{mg} / \mathrm{L})$ & $\mathrm{ND}$ & 2.7 & 9.8 \\
Lead $(\mu \mathrm{g} / \mathrm{L})$ & 190 & 5.3 & 2,453 \\
Manganese $(\mu \mathrm{g} / \mathrm{L})$ & 59,000 & 1,135 & 29,000 \\
Molybdenum $(\mu \mathrm{g} / \mathrm{L})$ & 10,000 & 3,200 & 281 \\
Nickel $(\mu \mathrm{g} / \mathrm{L})$ & 210,000 & 31 & 70 \\
Zinc $(\mu \mathrm{g} / \mathrm{L})$ & 16,000 & 71 & \\
\hline
\end{tabular}


As of June 2009, MDEQ had not adopted criteria for nutrients, although the USEPA had developed criteria for total nitrogen, total phosphorus, turbidity, and chlorophyll $a$ (U.S. Environmental Protection Agency, 2001). Nutrient criteria have not been developed for ammonia plus organic nitrogen and nitrate plus nitrite nitrogen, though these analytes were included in this study, and $25^{\text {th }}$ percentiles were reported within the USEPA's nutrient-criteria document. The USEPA recommended that these percentiles should be used as references and not specifically as water-quality criteria; however, according to Haack and Duris (2008) it is possible that these $25^{\text {th }}$-percentile values will be used if quality criteria are established in the future. Table 10 presents the $25^{\text {th }}$-percentile values for Nutrient Ecoregion VIII, subecoregion 50 streams, which include the Silver River Watershed (U.S. Environmental Protection Agency, 2001).

For the filtered samples, concentrations of nutrients in 33 of the 80 samples analyzed for ammonia plus organic nitrogen were equal to or greater than the $25^{\text {th }}$-percentile value; all but 2 of the samples analyzed for nitrate plus nitrite were equal to or exceeded the $25^{\text {th }}$-percentile value; and 2 of the 80 samples analyzed for total phosphorus were equal to or greater than the $25^{\text {th }}$-percentile value. For the unfiltered samples, 35 of the 80 samples analyzed for ammonia plus organic nitrogen were greater than the $25^{\text {th }}$-percentile value; and for samples analyzed for total phosphorus, 39 of the 80 samples were equal to or greater than the corresponding $25^{\text {th }}$-percentile values (table 9, fig. 18). Notably, 8 of 10 filtered samples and all 10 unfiltered samples collected at the East Branch Tributary to Gomanche Creek exceeded the $25^{\text {th }}$-percentile value for ammonia plus organic nitrogen criteria.

\section{Bed-Sediments Analysis}

Bed sediments were sampled at seven of the eight sites in conjunction with fish-tissue sampling in August 2008. The Silver River at Arvon Road site (04043131) was excluded owing to lack of suitable sediments at the site. Bed-sediment samples were collected and processed using methods described in the USGS NFM Chapter A8 (available online at http://pubs.water.usgs.gov/twri9A). The samples were analyzed for 42 metals and other selected elements at the USGS NWQL and for grain-size distribution at the Kentucky Water Science Center Sediment Laboratory.

Bed-sediment samples were composites of samples collected by hand with a Teflon scoop from each of 5 to 10 depositional zones (submerged during low streamflow) along a reach of approximately $150 \mathrm{~m}$. Samples were collected from the upper $2 \mathrm{~cm}$ (most recent, oxidized layer), and the amount collected depended upon the relative size of the depositional zone. Deposits of fine-grained sediment were targeted for sampling; thus, concentrations represent conditions in depositional areas of the streams, not the average concentrations for sediment throughout the stream reach. A bulk $<2-\mathrm{mm}$ fraction was removed from the composited sample from each site for particle-size analysis. The rest of the sample was wet-sieved in the field, and the fine $(<0.063 \mathrm{~mm})$ fraction was collected for trace-element analysis.

Results of the metals analysis are presented in appendix 2. Notably, two sites (upstream Gomanche Creek (04043135) and Silver River near L'Anse streamgage (04043150)) did not have concentrations of any elements that ranked highest overall among the seven sites. Conversely, three sites (West Branch Tributary to Gomanche Creek (04043138), Dakota Creek (04043146), and upper Silver River (04043126)) had the highest concentrations of many of the elements $(27,11$, and 8 , respectively). West Branch Tributary to Gomanche Creek had the highest concentrations of mercury, uranium, vanadium, and zinc. Dakota Creek had the highest concentrations of the rare-earth elements cerium and lanthanum, as well as rubidium and cesium. The upper Silver River and West Branch Tributary to Gomanche Creek had identical concentrations of nickel, niobium, and scandium, and the West Branch Tributary to Gomanche Creek and Dakota Creek had identical concentrations of cadmium. Figure 19 illustrates statistical analyses of the concentrations of bed sediment for all but bismuth, silver, and sulfur, which were below MDLs at all sampling sites. Once again, boxplots were chosen to most concisely present the data.

Table 10. Ambient water-quality criteria for select nutrients as defined by the U.S. Environmental Protection Agency within Nutrient Ecoregion VIII, Sub-ecoregion 50 (U.S. Environmental Protection Agency, 2001).

[All values are in milligrams per liter]

\begin{tabular}{lcccc}
\hline & $\begin{array}{c}\text { Ammonia plus } \\
\text { organic nitrogen }\end{array}$ & $\begin{array}{c}\text { Nitrate plus } \\
\text { nitrite nitrogen }\end{array}$ & Total nitrogen & Total phosphorus \\
\hline 25th percentile & 0.33 & 0.03 & 0.44 & 0.012 \\
\hline
\end{tabular}



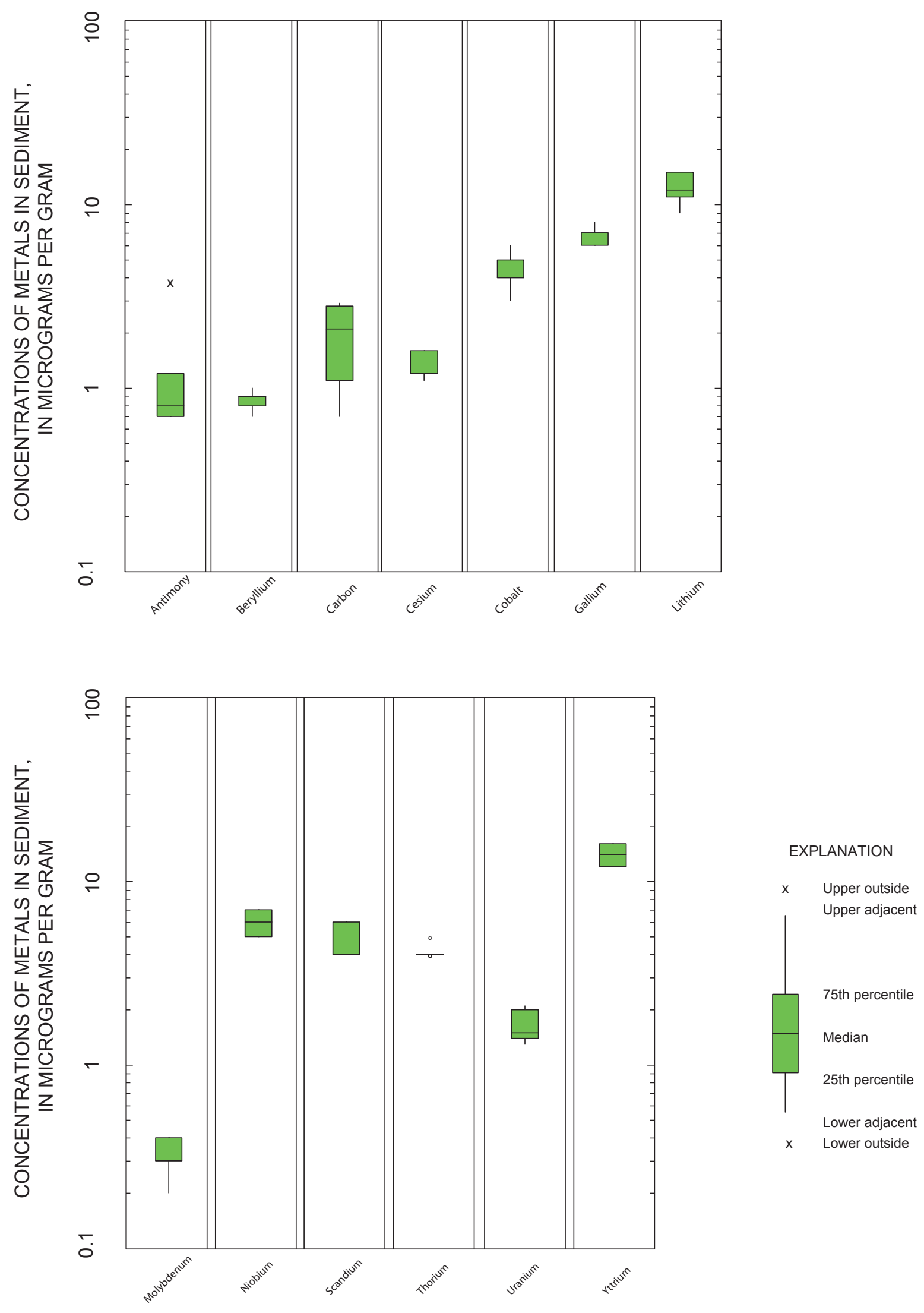

Figure 19. Concentration of metals in seven bed-sediment quality samples, Silver River Watershed, Michigan, 2005-08. 

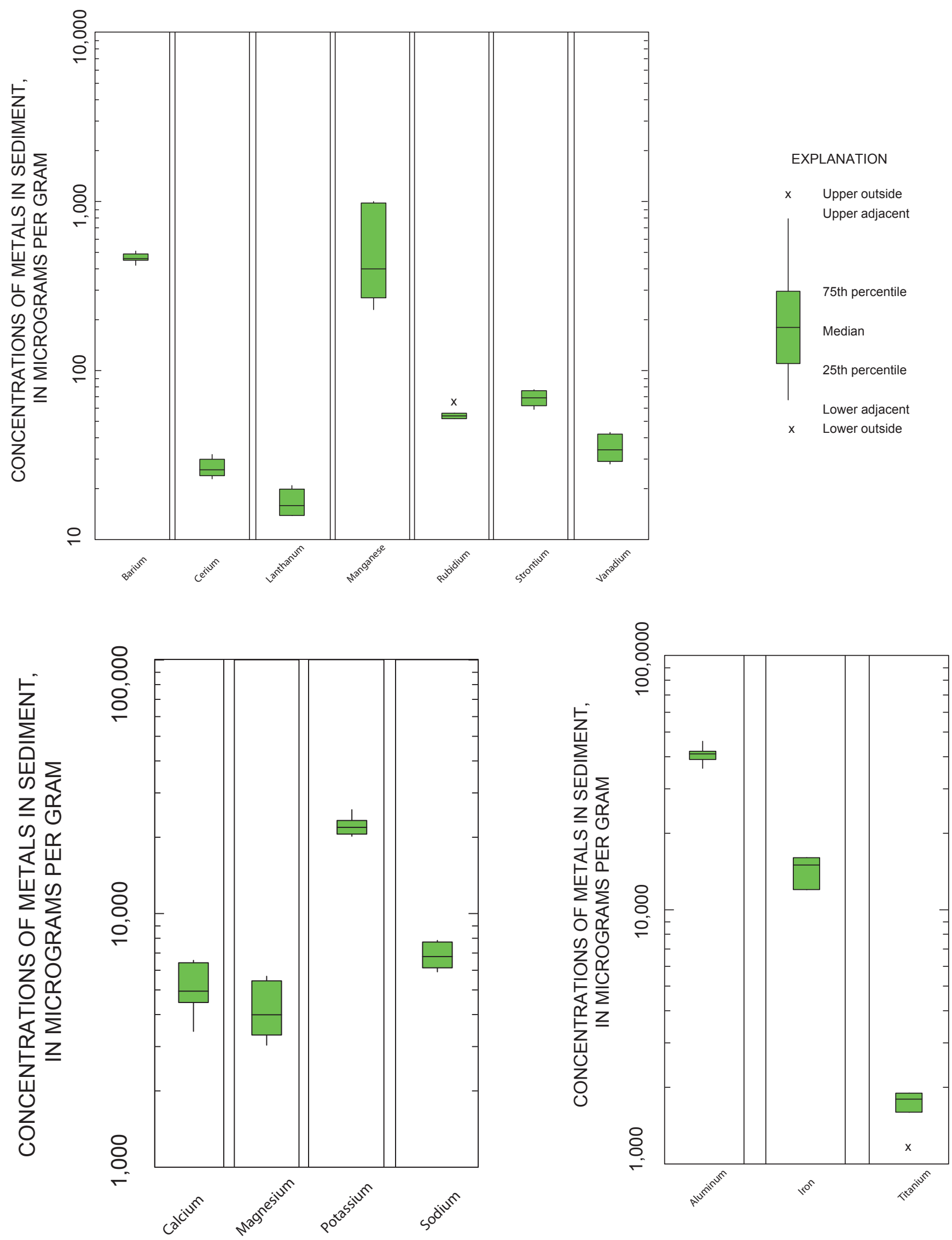

Figure 19. Concentration of metals in seven bed-sediment quality samples, Silver River Watershed, Michigan, 2005-08. - Continued 


\section{Comparison to Sediment-Quality Guidelines}

Sediment-quality guidelines often are built around concerns about specific groups of contaminants such as organochlorine insecticides, industrial organochlorine compounds such as polychlorinated biphenyls (PCBs), and polycyclic aromatic hydrocarbons (PAHs). Chemical analyses for this study focused on determining the concentrations for a full suite of metals, for which sediment-quality guidelines have been developed for only a small, select group of metals in sediments collected from freshwater streams and lakes.

MacDonald and others (2000) developed two criteria for bed sediment in freshwater environments: the thresholdeffect concentration (TEC), which represents the concentration above which adverse effects on biota are expected, and the probable-effect concentration (PEC), which defines the concentration above which adverse effects on biota are expected to occur frequently. These criteria were developed through a consensus-based analysis of six other numerical sedimentquality guidelines. Metals for which TECs and PECs have been defined are arsenic, cadmium, chromium, copper, lead, mercury, nickel, and zinc (table 11). All samples were below their corresponding TECs, although concentrations of arsenic and chromium approached their respective TECs (appendix 2 and fig. 20).

Table 11. Consensus-based sediment-quality guidelines for freshwater ecosystems (MacDonald and others, 2000).

[TEC, threshold effect concentration; $\mu \mathrm{g} / \mathrm{g}$, micrograms per gram; PEC, probable effect concentration]

\begin{tabular}{lcc}
\hline \multicolumn{1}{c}{ Constituent } & $\begin{array}{c}\text { TEC, } \\
\text { in } \boldsymbol{\mu g} / \mathbf{g}\end{array}$ & $\begin{array}{c}\text { PEC, } \\
\text { in } \boldsymbol{\mu g} / \mathbf{g}\end{array}$ \\
\hline Arsenic & 9.79 & 33 \\
Cadmium & .99 & 4.98 \\
Chromium & 43.4 & 111 \\
Copper & 31.6 & 149 \\
Lead & 35.8 & 128 \\
Mercury & .18 & 1.06 \\
Nickel & 22.7 & 48.6 \\
Zinc & 121 & 459 \\
\hline
\end{tabular}

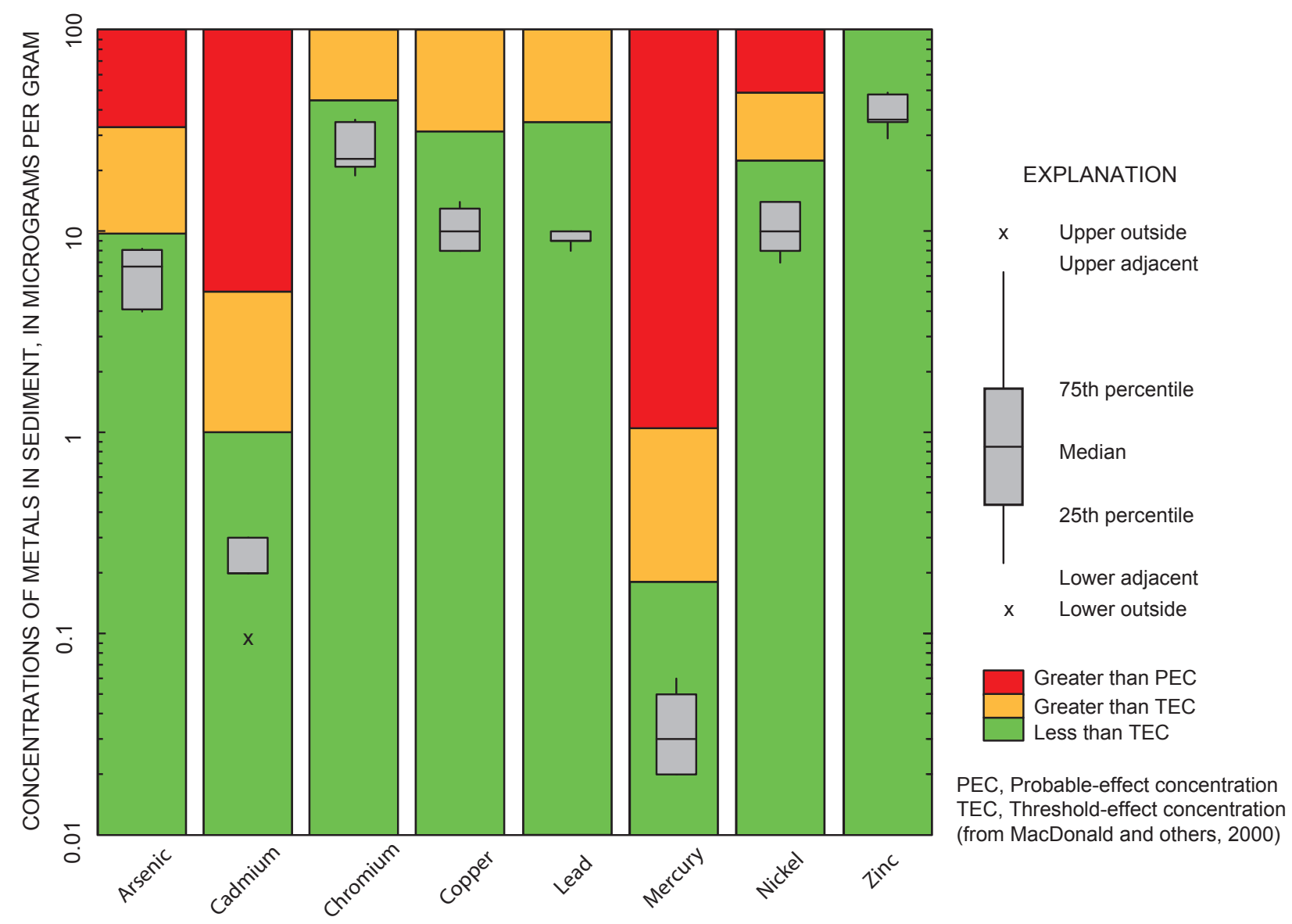

Figure 20. Concentration of metals in seven bed-sediment samples compared to sediment-quality guidelines, Silver River Watershed, Michigan, 2005-08 


\section{Grain-Size Distribution}

Analysis of grain-size distribution over time provides an important measure of physical changes within a watershed. Erosion and mass wasting, both natural and anthropogenic, can result in considerable changes in grain-size distribution within a watershed. This can occur gradually or catastrophically, depending upon the sediment source(s) being introduced into the stream.

Results of the grain-size distribution of bed sediments are shown in table 12. The silt and clay-size fraction (all sediments $<0.063 \mathrm{~mm}$ ) composed about 20 percent or less of the analyzed sediments in all of the streams and less than 7 percent in three streams (upper and lower Gomanche Creek (04043135 and 04043140, respectively) and East Branch Tributary to Gomanche Creek (04043137)). All sites except Dakota Creek (04043146) and Silver River near L'Anse (04043150) had visual accumulation (VA)-tube fractions (grain size 0.063 to $1.0 \mathrm{~mm}$ ) ranging from about 71 to 87 percent. The laboratory noted that not enough sample material was available for either of those sites and the VA tube was not used. It is noteworthy that all the streams have 20 percent or less silt/clay-sized materials, demonstrative of the high gradient typical throughout the watershed, which rapidly washes any fine-grained sediment out of the system.

\section{Ecological Investigation}

An ecological investigation of the Silver River sites that complements other parts of this study was conducted during August-September 2008. The investigation was completed using a modified version of the MDEQ GLEAS procedure 51, which is a qualitative-biological and habitat-survey protocol for wadeable streams that has been employed extensively in Michigan for several years (Michigan Department of Environmental Quality, 2007). The GLEAS 51 protocol consists of separate qualitative evaluations of the fish community, the macroinvertebrate community, and the habitat quality, completed in that order to minimize disruption of the sampled communities. The study team and KBIC Natural Resources Department chose the GLEAS 51 procedure for ease of application and comparison with other streams throughout the Upper Peninsula previously surveyed by the MDEQ. In the GLEAS 51 procedure, each survey station is described by up to three numbers or metrics; one each for the fish, macroinvertebrates, and habitat. An excellent-quality stream for the ecoregion would have the most metrics performing like an excellent site, while a poor-quality stream would have substantially different metrics. Use of metrics creates a uniform and systematic evaluation for each site with the result expressed as a single numerical value that easily is comparable to other sites. For this study, the habitat-assessment part of the GLEAS 51 procedure was not completed owing to budget constraints, as well as to the unaltered, inaccessible condition of most of the watershed.

\section{Fishes}

Much of the Silver River Watershed primarily is a coldwater fishery, with one or more species of salmonids present at several of the sampling sites. The GLEAS 51 protocol for coldwater fisheries is much simpler than for warm-water fisheries. Target streams are evaluated for the presence of at least 50 fish and the relative abundance of anomalies and salmonids collected (Michigan Department of Environmental Quality, 2007). For this study, the fish community part of the GLEAS 51 procedure was modified, targeting a single intolerant fish species (brook trout) as described in the next paragraph, although all shocked fish in each sampling reach were measured and identified. After a thorough reconnaissance of all eight water-quality sampling sites, the USGS and KBIC elected to sample reaches at the following four sites: upstream Silver River (04043126), Gomanche Creek (04043140), Dakota Creek (04043146), and Silver River near L'Anse (04043150). A summary of fish communities collected at the four sites is shown in table 13. Additional sites downstream of Silver River at Arvon Road (04043131) and upstream and downstream of Silver River near L'Anse streamgage (04043150) also were sampled, but stream conditions at those locations were either poor (no fish habitat) or channel composition (depths; high gradients; channels composed entirely of slaty bedrock) made electrofishing difficult to impossible.

USGS and KBIC crews used a combination of backpack and barge-shocking units to conduct the survey, targeting native (not hatchery stocked) 3- to 4-year-old brook trout (Salvelinus fontinalis), with some success in Gomanche Creek (two fish) and Dakota Creek (three fish). Low-conductivity

Table 12. Bed-sediment grain-size distribution for selected sites in the Silver River Watershed, Michigan.

[All values are in percent of total; silt/clay is grain sizes less than $0.063 \mathrm{~mm}$; visual accumulation tube is grain sizes 0.063 to 1.0 millimeter; sieve is grain sizes 1.0 to 4.0 millimeters]

\begin{tabular}{lccccccc}
\hline & \multicolumn{7}{c}{ U.S. Geological Survey site number } \\
& $\mathbf{4 0 4 3 1 2 6}$ & $\mathbf{4 0 4 3 1 3 5}$ & $\mathbf{4 0 4 3 1 3 7}$ & $\mathbf{4 0 4 3 1 3 8}$ & $\mathbf{4 0 4 3 1 4 0}$ & $\mathbf{4 0 4 3 1 4 6}$ & $\mathbf{4 0 4 3 1 5 0}$ \\
\hline Silt/clay & 12.3 & 4.5 & 5.7 & 20.2 & 15.4 & 11.1 \\
Visual accumulation tube & 83.1 & 70.8 & 86.6 & 73.2 & 82 & 6.5 \\
Sieve & 4.6 & 24.7 & 7.7 & 6.6 & 2.6 & 0 & 88.9 \\
\hline
\end{tabular}


Table 13. Summary of fish communities collected at sites in the Silver River Watershed, Michigan.

[USGS, U.S. Geological Survey]

\begin{tabular}{lcccc}
\hline USGS station number & Number of fish collected & $\begin{array}{c}\text { Number of fish } \\
\text { species collected }\end{array}$ & $\begin{array}{c}\text { Number and type of Salmonid } \\
\text { species collected }\end{array}$ & Tissues collected? \\
\hline 04043126 & 40 & 5 & 0 & No \\
04043140 & 16 & 1 & 1 (brook trout) & Yes \\
04043135 & 52 & 4 & 1 (brook trout) & Yes \\
04043150 & 74 & 11 & 4 (brook trout, rainbow trout, \\
& & & coho salmon, pink salmon) & No \\
\hline
\end{tabular}

waters at all sites made the electrofishing equipment somewhat less efficient than is ideal for fish capture; however, taking into account that capture efficiency may have biased total fish counts, it was clear that fish populations at all the sites were low. Sampling at the downstream-most site on the Silver River (streamgage 04043150) produced the largest number of individuals and the most species of all the sites; however, all the brook trout captured at this site were fin clipped indicating they were hatchery-bred fish introduced by stocking. Since the residence time of hatchery fish in a stream is uncertain, and thus, exposure to any potential contaminants in the stream is unknown, no fish from this site were submitted for tissue analysis. Fish filets were processed on site (fig. 21) and analyzed for metals at Texas A\&M University; results of the metal analyses are presented in table 14. Fish otoliths, which are small parts located in the head of fish that assist with hearing, accrete layers of calcium carbonate and gelatinous matrix throughout the fish's life. The accretion rate varies with growth of the fish, often less growth in winter and more in summer, which results in the appearance of rings that resemble tree rings. By counting the rings, it is possible to determine the age of the fish in years. Fish otoliths were examined by two independent laboratories. Three samples met the targeted-age criteria ( 3 to 4 years of age): one sample was dated 2 years of age; and one sample was destroyed while being mounted for analysis, and its age is unknown. No notable concentrations of metals were detected in any of the five fish analyzed.

Presence of brook trout at all but the upstream Silver River site is an indication of good water quality in much of the watershed. Brook trout are intolerant of poor water quality, low dissolved-oxygen concentrations, and water temperatures greater than $21-23^{\circ} \mathrm{C}$.

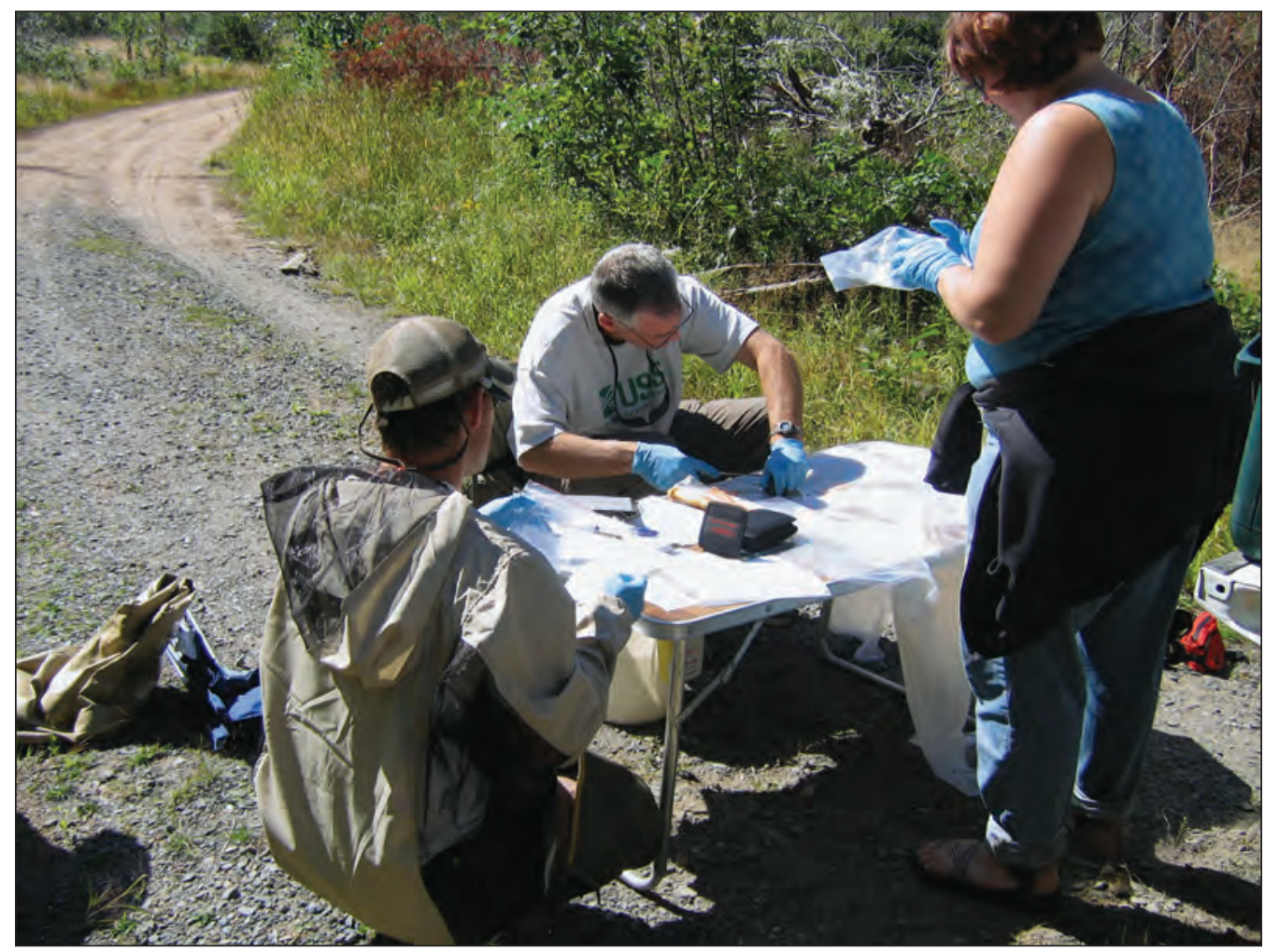

Figure 21.

U.S. Geological Survey employees processing adult brook trout at Dakota Creek (site 04043146), August 26, 2008. (Photograph by T.L. Weaver, U.S. Geological Survey) 
Table 14. Concentrations of trace-elements in brook-trout tissue samples taken from the Silver River Watershed, Michigan.

[ID, identification; <, less than; all concentrations in micrograms per kilogram]

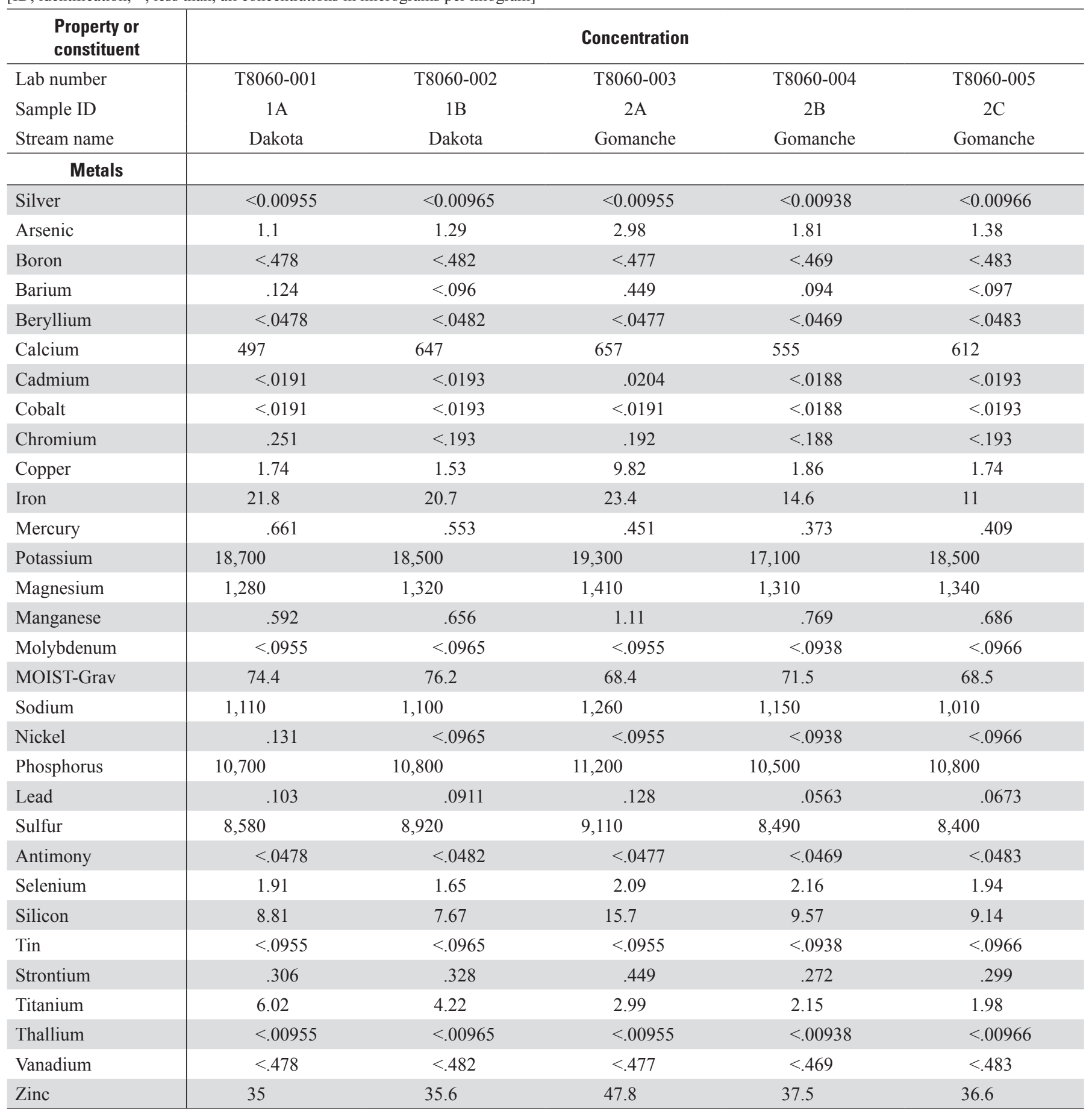




\section{Macroinvertebrate Sampling}

Macroinvertebrates were collected from all eight sampling sites on September 16 and 17, 2008. Following the GLEAS 51 procedure, samples were collected from all available habitats using either a D-frame kick net (fig. 22) or they were hand-picked. Fixed substrates were scrubbed with a small brush to dislodge organisms, as necessary. Samples were taken from all velocity regimes within the study reach as well, with consideration given to sampling all regimes proportionally to their relative abundance. The target quantity of organisms $300 \pm 60$ was met or exceeded at all sites except the Silver River at Arvon Road (04043131), which primarily is composed of boulders and bedrock, with less-suitable macroinvertebrate habitat than the other sites. The macroinvertebrate samples were preserved in ethanol and brought back to USGS offices where they were examined, sorted, and classified.
Figure 23 shows a sorting tray in the field with insects and detritus prior to removal of detritus.

Scoring is simple. For streams within the northern lakes and forests category, which all parts of the Silver River Watershed fall under, the following metrics apply: poor is -9 or less, acceptable is -4 , and excellent is 5 and greater. Six of the sites scored excellent, with scores of 6 or 7, while two were slightly less than excellent. The upstream Silver River at streamgage 04043126 scored 4, which is not surprising given the channel is sandy and low-gradient, vegetation is dominated by tag elders and other bushes, and no salmonids were observed during electrofishing. More surprisingly, the downstream Gomanche Creek site (streamgage 04043140), which is fairly high-gradient, wooded, harbored brook trout, and certainly appears to be better habitat than the upstream Silver River site, scored 3. Appendix 3 is a summary of the macroinvertebrate-sampling results.

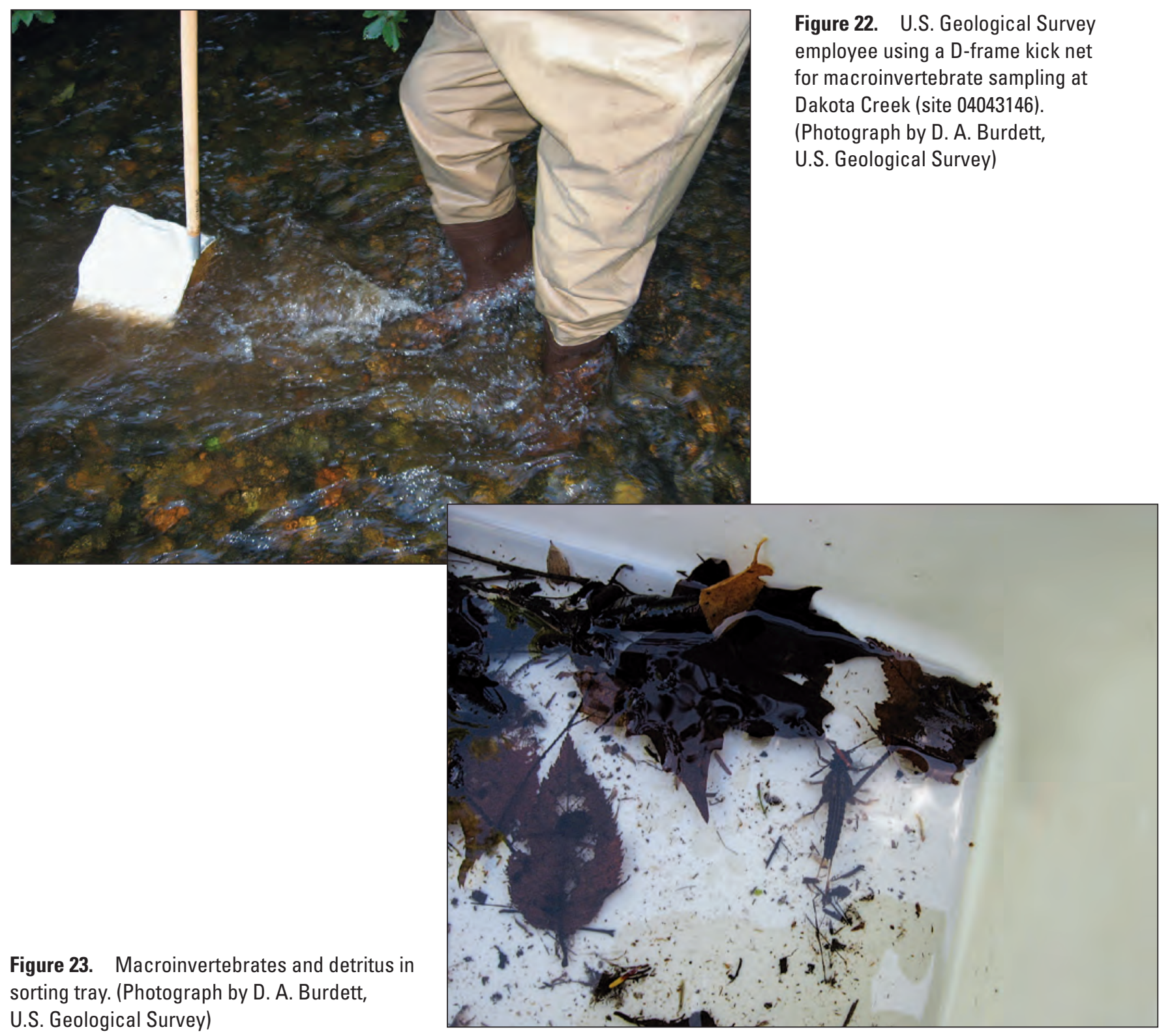




\section{Summary and Conclusions}

The U.S. Geological Survey, in cooperation with Keweenaw Bay Indian Community, conducted a study during 2005-08 to (1) evaluate baseline hydrology and water quality, (2) conduct an ecological assessment of the Silver River Watershed, and (3) address tribal concerns. Streamflow was measured; water-quality samples were collected; and an ecological assessment was conducted at eight locations within the central and western parts of the 69-square mile Silver River Watershed. The U.S. Geological Survey and Keweenaw Bay Indian Community cooperatively operate three real-time streamgages and water-quality monitors within the watershed; two were installed as a complement to this study. Waterquality sampling was done 2 to 3 times per year, including, at a minimum, once shortly after ice-out in the spring and once during the summer baseflow period. Additional samplings during the year were coordinated by the U.S. Geological Survey and Keweenaw Bay Indian Community to encompass different runoff and streamflow scenarios, for example, immediately following a heavy summer precipitation event in 2006.

The water-quality characteristics of the streams within the Silver River Watershed are typical of many streams flowing through sparsely populated areas in the central Upper Peninsula of Michigan. Of note, seven samples had copper concentrations exceeding Michigan wildlife standards, and one sample had concentrations of cyanide that exceeded the same standards. Concentrations of total mercury at all eight sampling sites, from a low-flow sampling in 2008, exceeded the Great Lakes Basin water-quality standards, but the ratio of methylmercury to total mercury was similar to the 5 to 10 percent typical in most natural waters. Concentrations of arsenic and chromium in bed sediments were near the threshold-effect concentration. An ecological assessment analyzing fish and macroinvertebrate communities, by use of a modified version of the Michigan Department of Environmental Quality Great Lakes Environmental Assessment Section 51 procedure, was conducted in 2008. Numbers of intolerant, coldwater salmonids were noted at all but one sampling site, and six of the eight sites scored excellent for their macroinvertebrate communities (the remaining two sites scored slightly less than excellent).

Additional water-quality data were collected by the U.S. Geological Survey and Keweenaw Bay Indian Community during 2009, and all three real-time streamflow-gaging and water-quality monitoring sites continue to operate. This report will aid in an ongoing monitoring effort designed to protect the water resources of the Silver River Watershed.

\section{Acknowledgments}

Special thanks are extended to the staff at KBIC, including previous and current water-quality specialists, Marc Slis and Micah Petosky, respectively, for their assistance in the preparation and review of the QAPP, help in establishing sampling sites, and assistance throughout the project. Todd Warner, Director, KBIC Natural Resources is thanked for his oversight of the project since inception. Dean Burdett, Matt Holmio, Steve Horton, and John Knudsen, USGS Michigan Water Science Center, Escanaba Field Office; Rick Jodoin and Lori Fuller, USGS Michigan Water Science Center; and Amanda Bell and Barb Scudder, USGS Wisconsin Water Science Center are thanked for their assistance to the authors with many aspects of report preparation.

\section{References Cited}

Cannon, W.F., and Ottke, Doug, 1999, Preliminary digital geologic map of the Penokean (early Proterozoic) continental margin in northern Michigan and Wisconsin: U.S. Geological Survey Open-File Report 99-547, 1 CD-ROM, accessed October 20, 2009, at http://pubs.usgs.gov/of/1999/of99-547/.

Carter, R.W., and Davidian, Jacob, 1968, General procedure for gaging streams: U.S. Geological Survey Techniques of Water-Resources Investigations, book 3, chap. A6, 13 p., accessed October 20, 2009, at http://pubs.usgs.gov/twri/ twri3-A6/.

Doonan, C.J., and Byerlay, J.R., 1973, Ground water and geology of Baraga County, Michigan: State of Michigan Geological Survey Water Investigation 11, 26 p.

Farrand, W.R., and Bell, D.L., 1982, Quaternary geology of northern Michigan: Ann Arbor, Mich., University of Michigan, Department of Geological Sciences, scale 1:500,000.

France, G.M., Bendall, K.A., and Lefevre, M.L., comps 2005, Groundwater flow model of the Silver River Watershed, Keweenaw Bay Indian Community, Baraga County, Michigan: [Houghton, Mich.] Michigan Technological University, Aqua Terra Tech, 8 p.

Haack, S.K., and Duris, J.W., 2008, Chemical and microbiological water quality of subsurface agricultural drains during a field trial of liquid dairy manure effluent application rate and varying tillage practices, Upper Tiffin Watershed, southeastern Michigan: U.S. Geological Survey Open-File Report 2008-1189, 38 p., accessed October 20, 2009, at http://pubs.usgs.gov/of/2008/1189/.

Helsel, D.R., 2005a, Nondetects and data analysis-Statistics for censored environmental data: Hoboken, N.J., Wiley, 250 p. 
Helsel, D.R., 2005b, Insider censoring-Distortion of data with nondetects: Human and Ecological Risk Assessment, v. 11, p. $1127-1137$.

Helsel, D.R., and Hirsch, R.M., 2002, Statistical methods in water resources: U.S. Geological Survey Techniques of Water-Resources Investigations, book 4, chap. A3, accessed May 27, 2009, at http://pubs.usgs.gov/twri/twri4a3/.

Hem, J.D., 1985, Study and interpretation of the chemical characteristics of natural water ( $3 \mathrm{~d}$ ed.): U.S. Geological Survey Water-Supply Paper 2254, 264 p.

Illinois State Geological Survey, 2009, Timetable of Quaternary glacial and interglacial events, accessed on November 23, 2009, at http://www.isgs.uiuc.edu/research/glacialgeology/timetable.shtml.

Krabbenhoft, D.P., and Rickert, D.A., 1995, Mercury contamination of aquatic ecosystems: U.S. Geological Survey Fact Sheet 216-95, 4 p., accessed October 20, 2009, at http://pubs.usgs.gov/fs/1995/fs216-95/.

Leverett, Frank, 1929, Moraines and shore lines of the Lake Superior Region: U.S. Geological Survey Professional Paper 154-A, 72 p.

MacDonald, D.D., Ingersoll, C.G., and Berger, T.A., 2000, Development and evaluation of consensus-based sedimentquality guidelines for freshwater ecosystems: Archives of Environmental Contamination and Toxicology, v. 39, p. $20-31$.

Michigan Department of Environmental Quality, 2006a, Part 4-Water quality standards: Lansing, Mich., Michigan Department of Environmental Quality, Water Bureau, Water Resources Protection, 62 p., accessed May 27, 2009, at http://www.michigan.gov/documents/deq/wb-swas-rulespart4_254149_7.pdf

Michigan Department of Environmental Quality, 2006b, Rule 57-Water quality values: Lansing, Mich., Michigan Department of Environmental Quality, Surface Water Assessment Section, accessed May 27, 2009, at http://www. michigan.gov/deq/0,1607,7-135-3313_3686_3728-11383-,00.html

Michigan Department of Environmental Quality, 2007, Qualitative biological and habitat survey protocols for wadeable streams and rivers (May 2007 rev.): Lansing, Mich., Michigan Department of Environmental Quality, Surface Water Quality Division, Great Lakes Environmental Assessment Section Procedure Number 51, $51 \mathrm{p}$.

Michigan Department of Environmental Quality, 2008, Rule 57-Water quality values, accessed July 9, 2008, at http://www.michigan.gov/documents/deq/wb-swasrule57_210455_7.xls
Michigan Department of Natural Resources, Forest, Mineral and Fire Management Division, 2003, IFMAP/GAP Upper Peninsula Land Cover.

Moulton, S.R., II, Kennen, J.G., Goldstein, R.M., and Hambrook, J.A., 2002, Revised protocols for sampling algal, invertebrate, and fish communities as part of the National Water-Quality Assessment Program: U.S. Geological Survey Open-File Report 02-150, 75 p., accessed October 21, 2009, at http://pubs.usgs.gov/of/2002/ofr-02$150 /$.

National Climatic Data Center, 2002, Monthly station normals of temperature, precipitation, and heating and cooling degree days, 1971-1996: Asheville, N.C., National Climatic Data Center.

National Climatic Data Center, 2008, Monthly station normals of temperature, precipitation, and heating and cooling degree days, 2005-08: Asheville, N.C., National Climatic Data Center.

Oblinger-Childress, C.J., Foreman, W.T., Connor, B.F., and Maloney, T.J., 1999, New reporting procedures based on long-term method detection levels and some considerations for interpretations of water-quality data provided by the U.S. Geological Survey National Water-Quality Laboratory: U.S. Geological Survey Open-File Report 99-193, 19 p., accessed October 21, 2009, at http://water.usgs.gov/owq/ OFR_99-193/index.html

Rantz, S.E., and others, 1982, Measurement and computation of streamflow-Volume 1, Measurement of stage and discharge: U.S. Geological Survey Water-Supply Paper 2175, 284 p., accessed October 21, 2009, at http://pubs.usgs.gov/ wsp/wsp2175/.

Rossell, Dean, 2008, Geology of the Keweenawan BIC Intrusion, in Bornhorst, T.J., and Klasner, J.S., eds., Proceedings of the 54 ${ }^{\text {th }}$ Institute on Lake Superior Geology, Volume 54, Part 2: Field Trip Guidebook, p. 181-199.

Smith, S.M., 1997, National geochemical database-Reformatted data from the National Uranium Resource Evaluation (NURE) Hydrogeochemical and Stream Sediment Reconnaissance (HSSR) Program (ver. 1.40): U.S. Geological Survey Open-File Report 97-492, accessed October 21, 2009, at http://pubs.usgs.gov/of/1997/492/ index.html

Sweat, M.J., and Rheaume, S.J., 1998, Water resources of the Keweenaw Bay Indian Community, Baraga County, Michigan: U.S. Geological Survey Water-Resources Investigations Report 98-4060, 33 p. 
Trahan, Melissa, Ward, Adam, Culberson, Shannon, Krevinghaus, Andrea, and LeFevre, Greg, 2005, Hydrologic model of the Silver River Watershed, Baraga County, Michigan: [Houghton, Mich.] Michigan Technological University, Aqua Terra Tech, $23 \mathrm{p}$.

U.S. Environmental Protection Agency, 1995a, Great Lakes water quality initiative technical support document for human health criteria and values: Washington, D.C., U.S. Environmental Protection Agency, Office of Water, EPA 820-B95-007.

U.S. Environmental Protection Agency, 1995b, Great Lakes water quality initiative technical support document for wildlife criteria: Washington, D.C., U.S. Environmental Protection Agency, Office of Water, EPA 820-B95-009.

U.S. Environmental Protection Agency, 2001, Ambient water quality criteria recommendations - Information supporting the development of State and Tribal nutrient criteria, rivers and streams in Nutrient Ecoregion VIII: Washington, D.C., Office of Water, EPA 822-b-01-015, 142 p.

U.S. Fish and Wildlife Service, 1994, National wetlands inventory, accessed October 21, 2009, at http://www.fws. gov/wetlands/.

U.S. Geological Survey [variously dated], National field manual for the collection of water-quality data: U.S. Geological Survey Techniques of Water-Resources Investigations, book 9, chaps. A1-A9, accessed October 21, 2009, at http://water. usgs.gov/owq/FieldManual/.

Weaver, T.L., and Fuller, L.M., 2007, Stream-water quality during storm-runoff events and low-flow periods in the St. Clair River/Lake St. Clair Basin, Michigan: U.S. Geological Survey Open-File Report 2007-1201, 13 p., accessed October 21, 2009, at http://pubs.usgs.gov/ of/2007/1201/.

Wisconsin Department of Natural Resources, 2004, Surfacewater-quality standards and policy, Table 9 , Sensitivity of lakes to acid rain, accessed March 18, 2010, at http:// learningstore.uwex.edu/assets/pdfs/G3582.pdf 


\section{Appendixes}




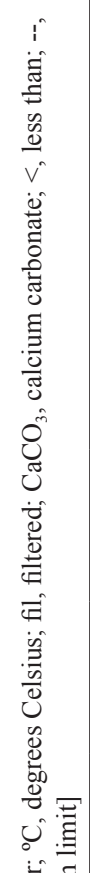

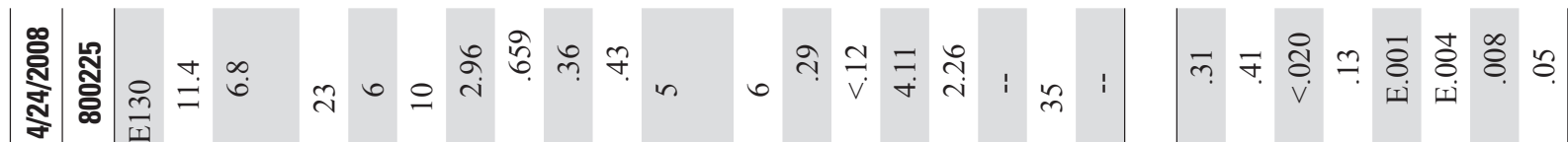

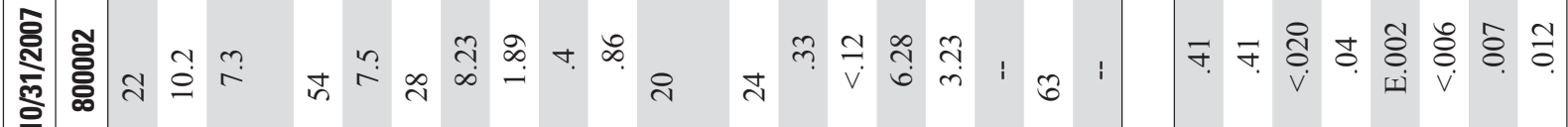

商

$\stackrel{2}{2}$

商

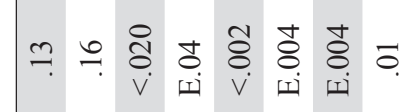

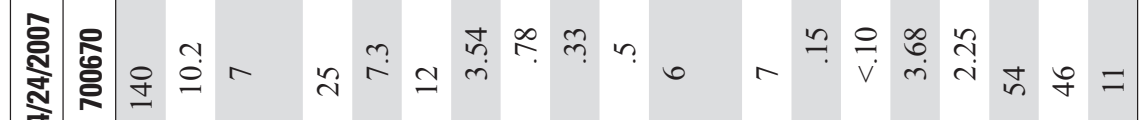

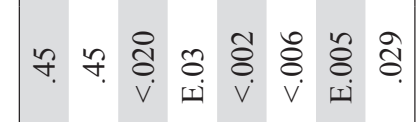

읍

$\pi$

药

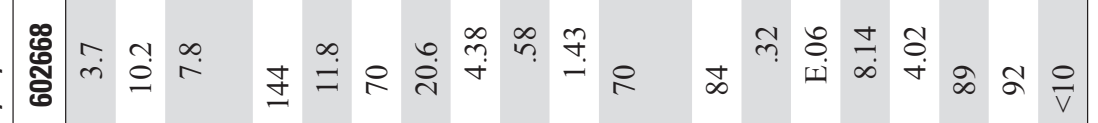

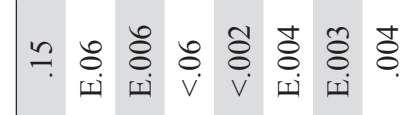

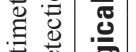

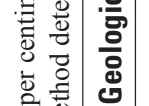

要

要党

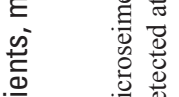

离

要

है

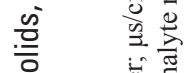

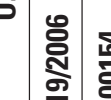

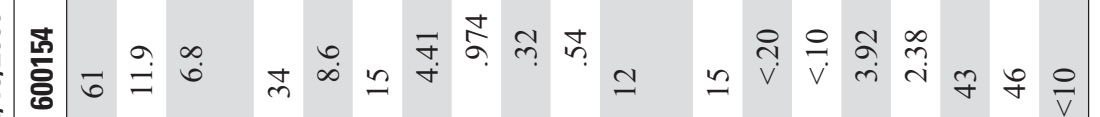

空

离宽

焉

章署

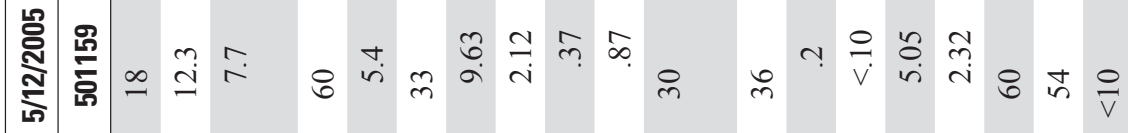

㲅产

语离

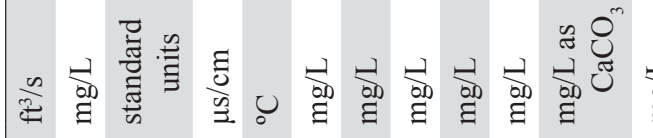

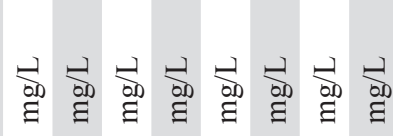

$z z_{1} z_{2} z_{0}$

I

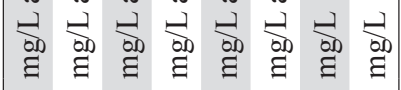

○ัँ

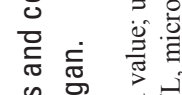

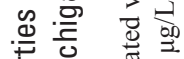

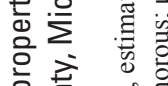

竞言坵

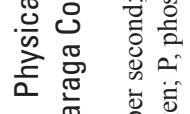

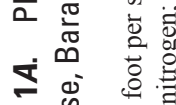

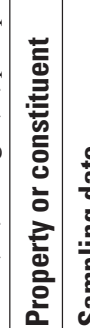
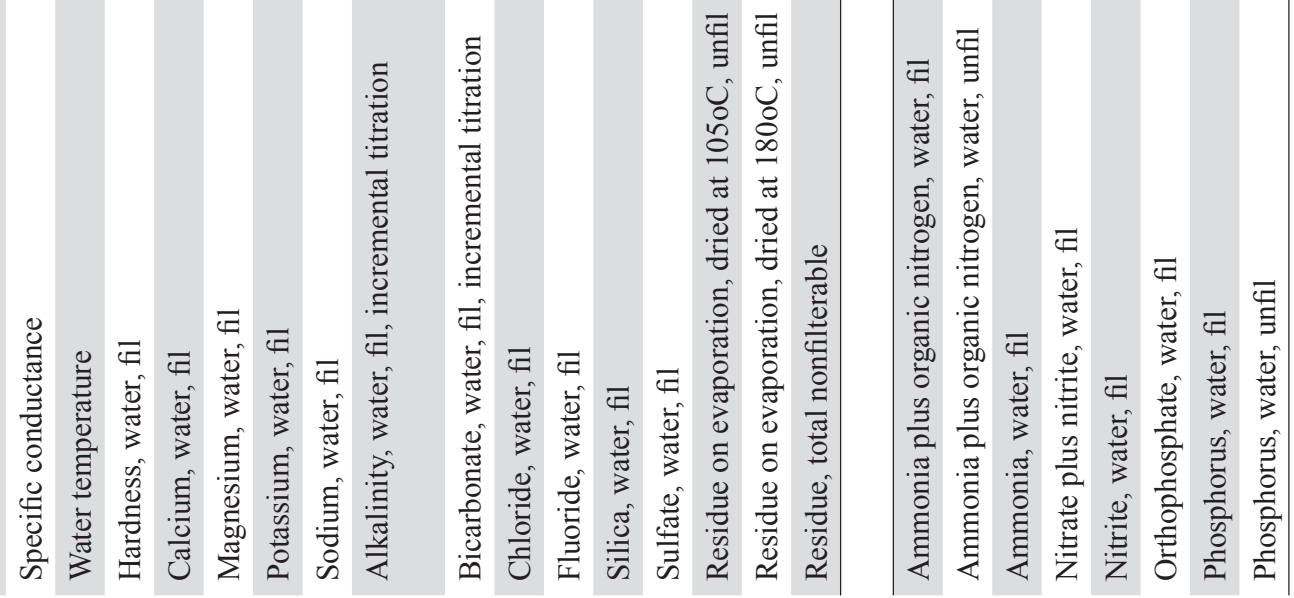


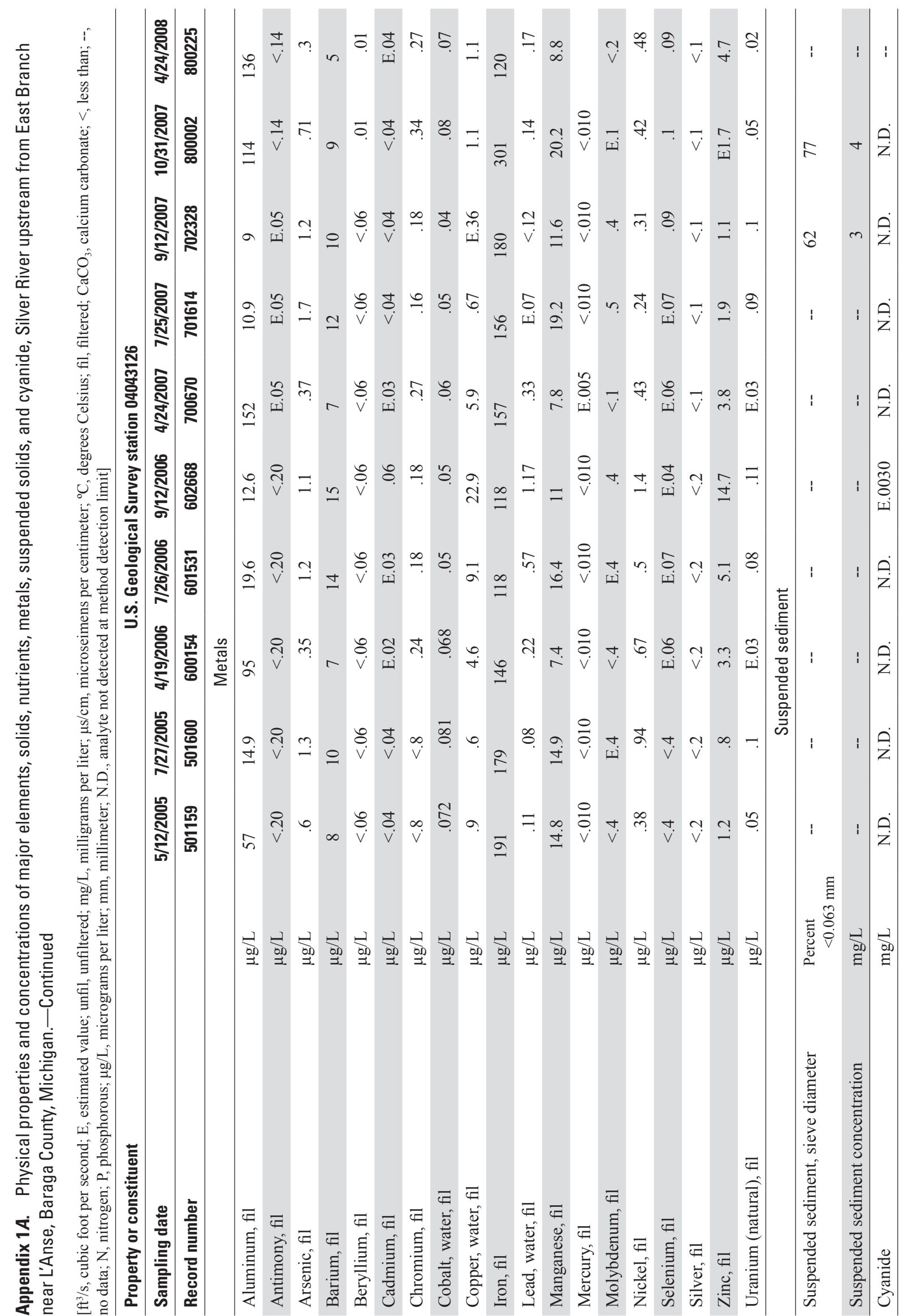




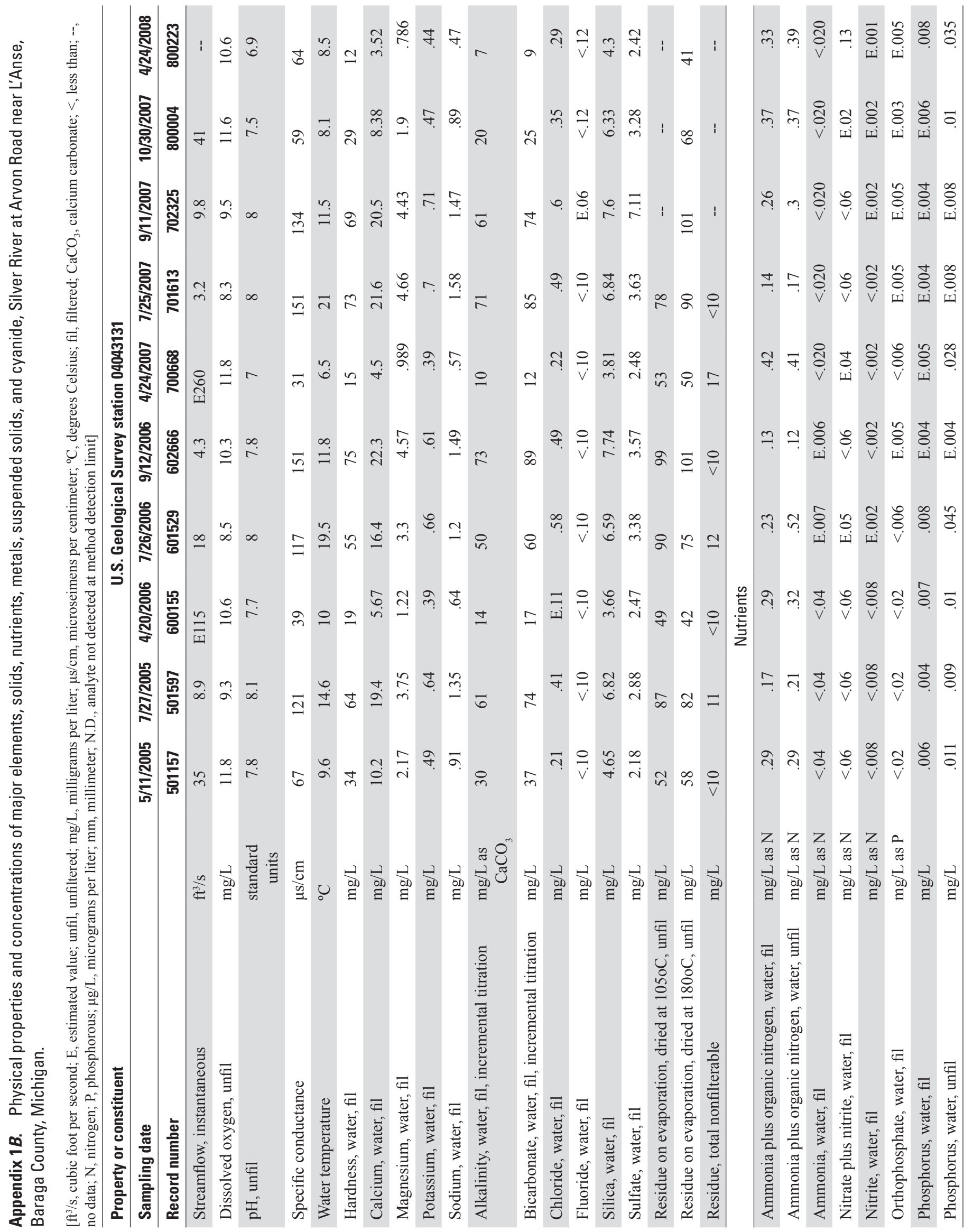




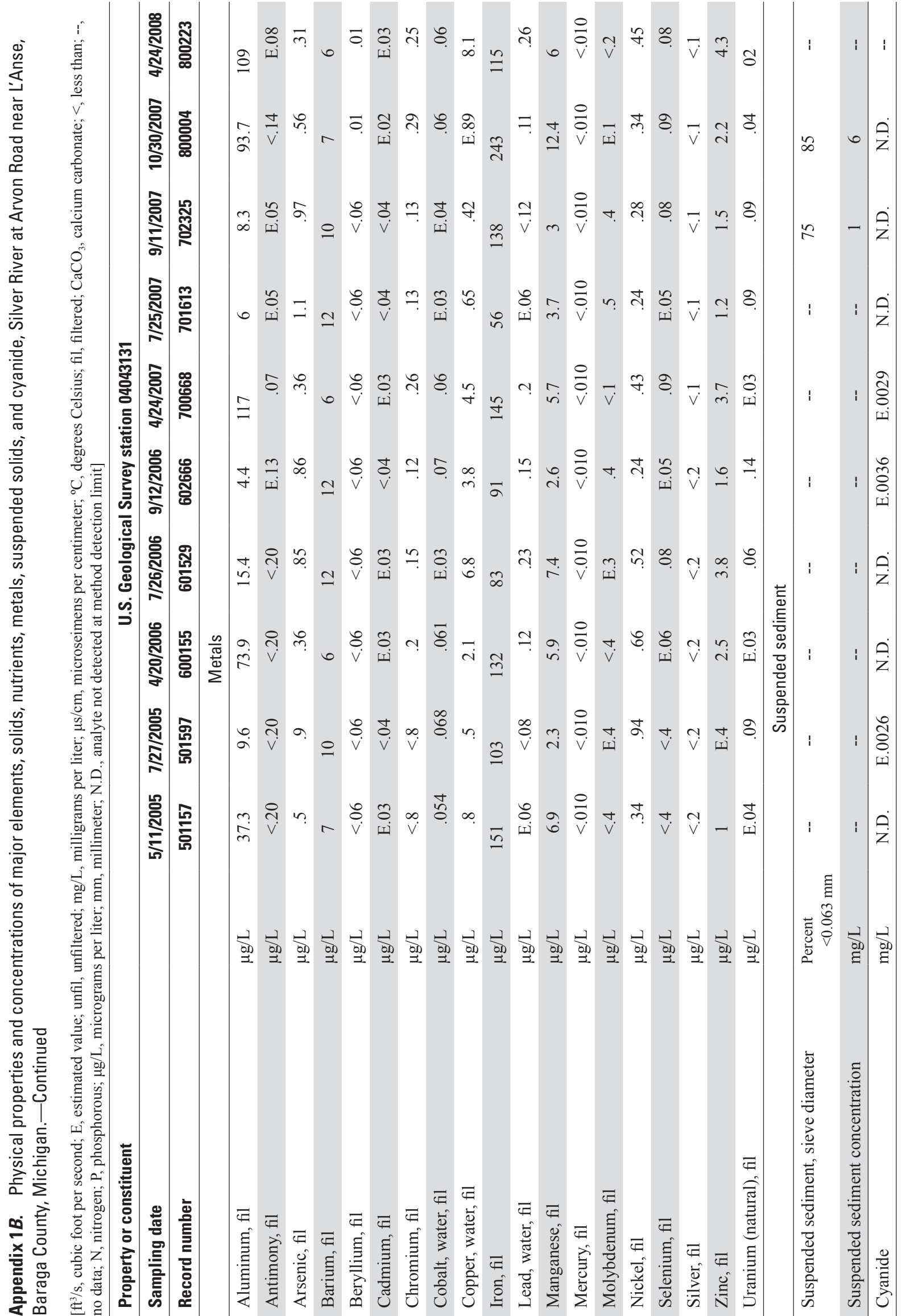




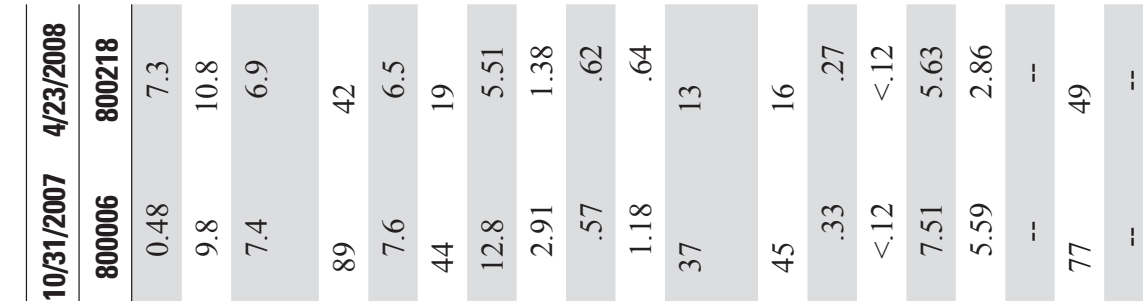

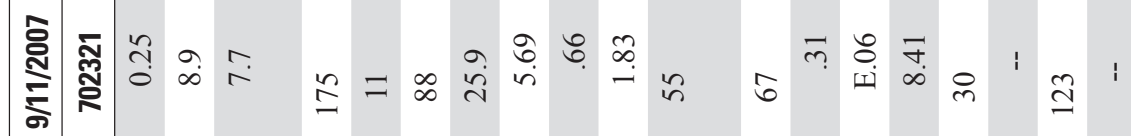
냉

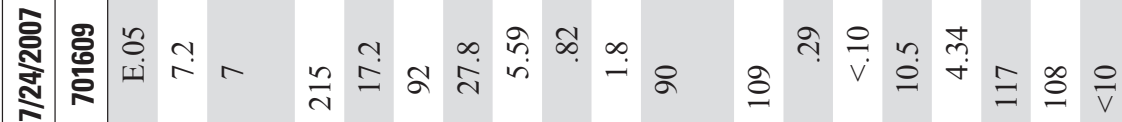

高

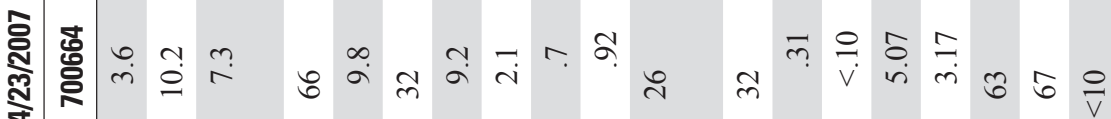

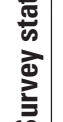

﨎

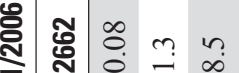

.

苟

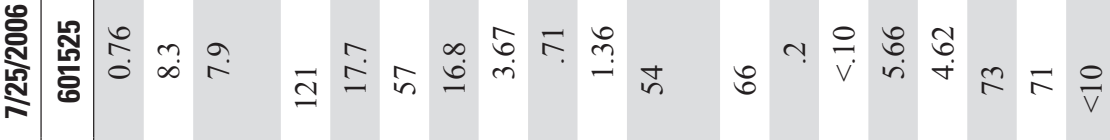

כ

䆓

.

is

c)

总

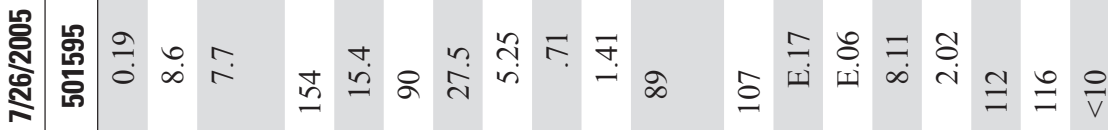

年

范

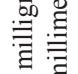

究

कิ

过 离

竞

武产

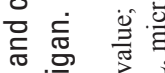

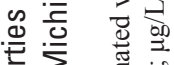

능

은

든 ज윰

đٓ

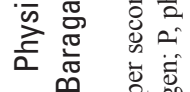

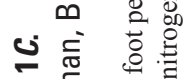

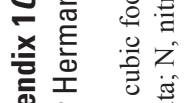

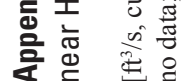

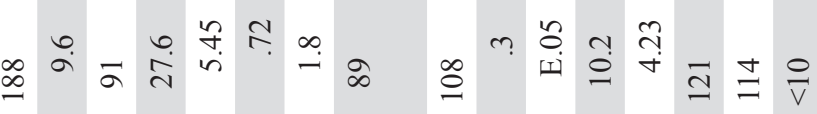

m

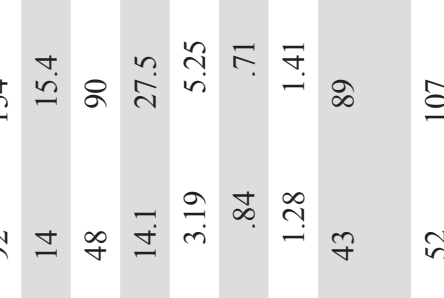

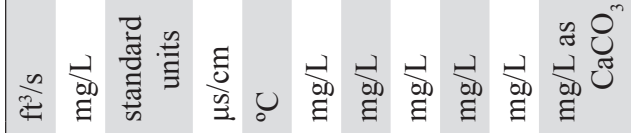

80

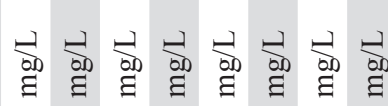

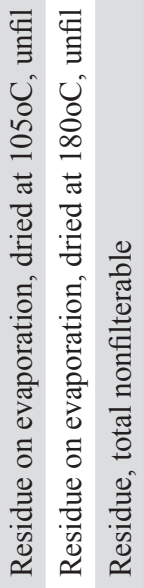

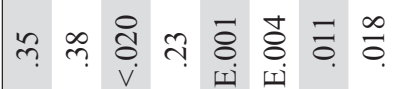

m.

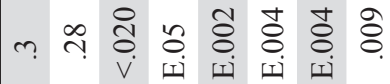

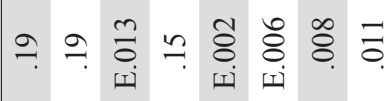

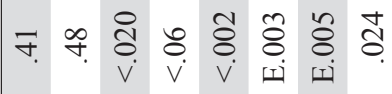

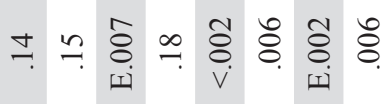

m f.

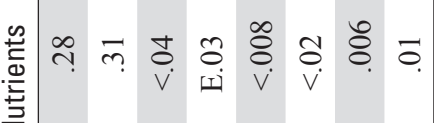
m. चา

Z Z Z Z Z o

జ

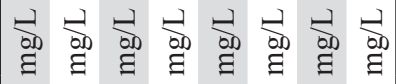

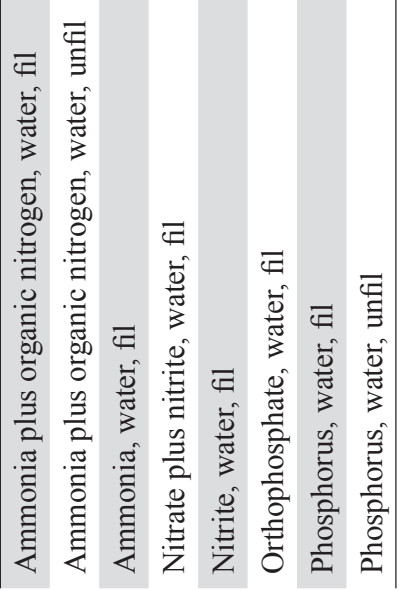




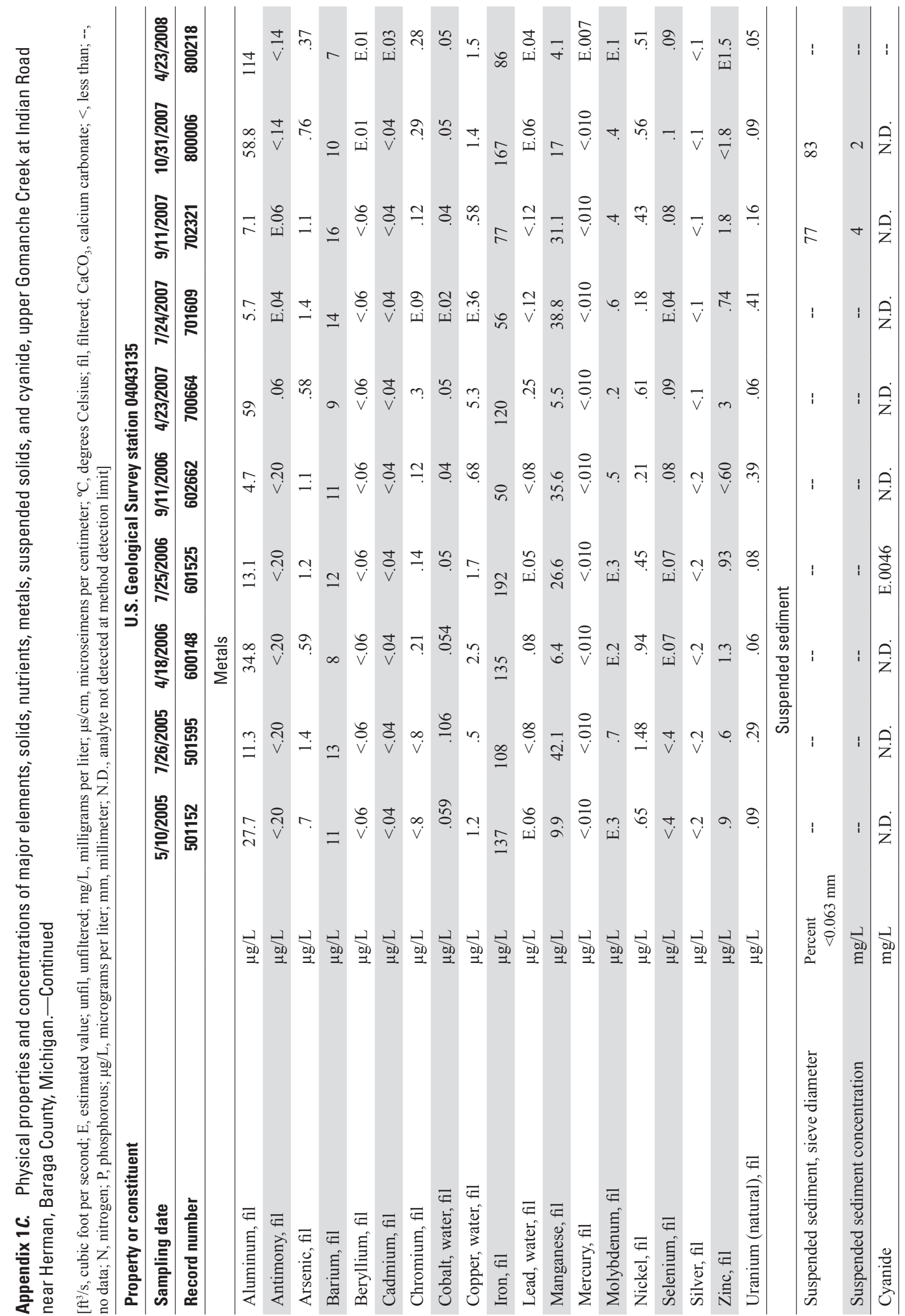




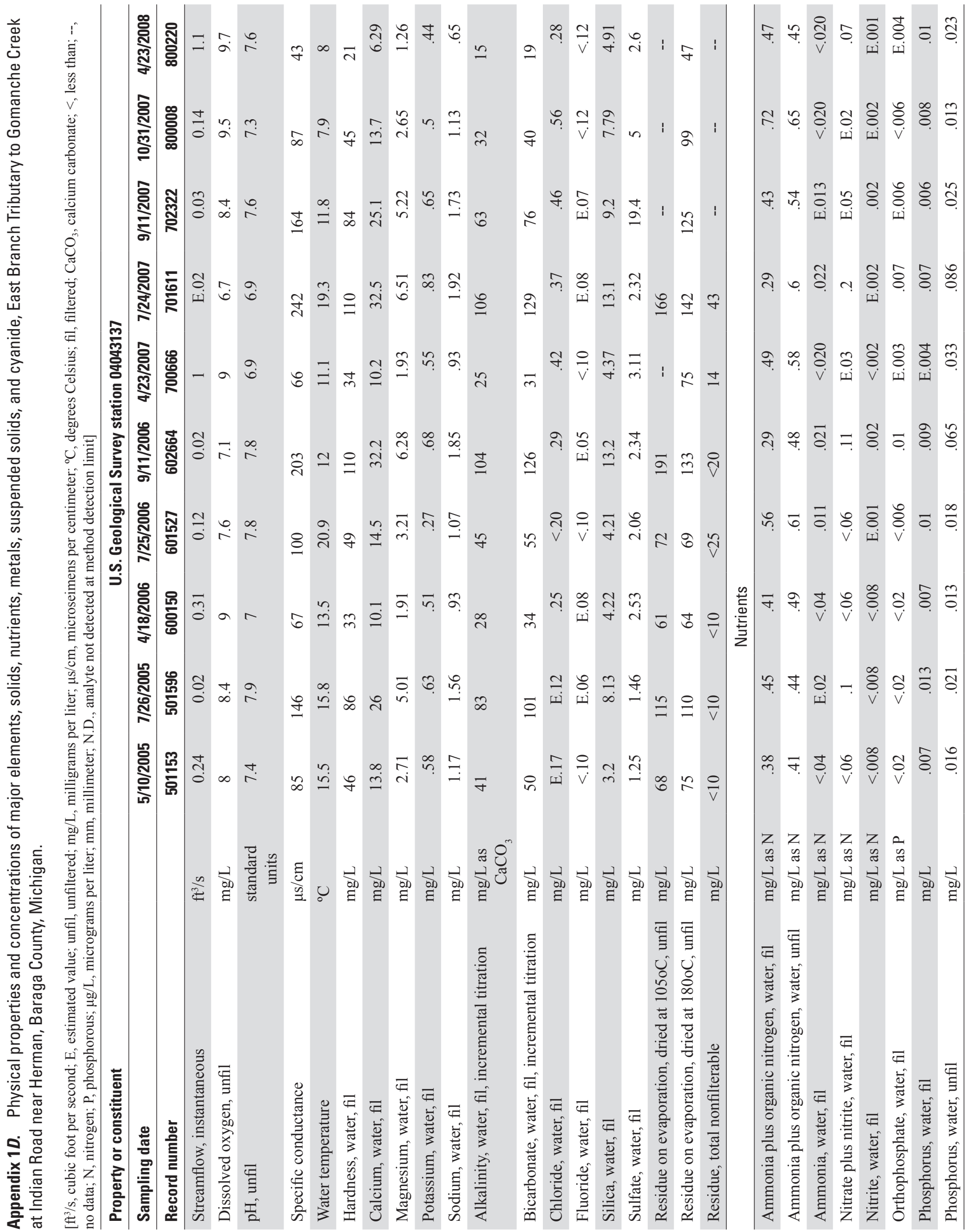




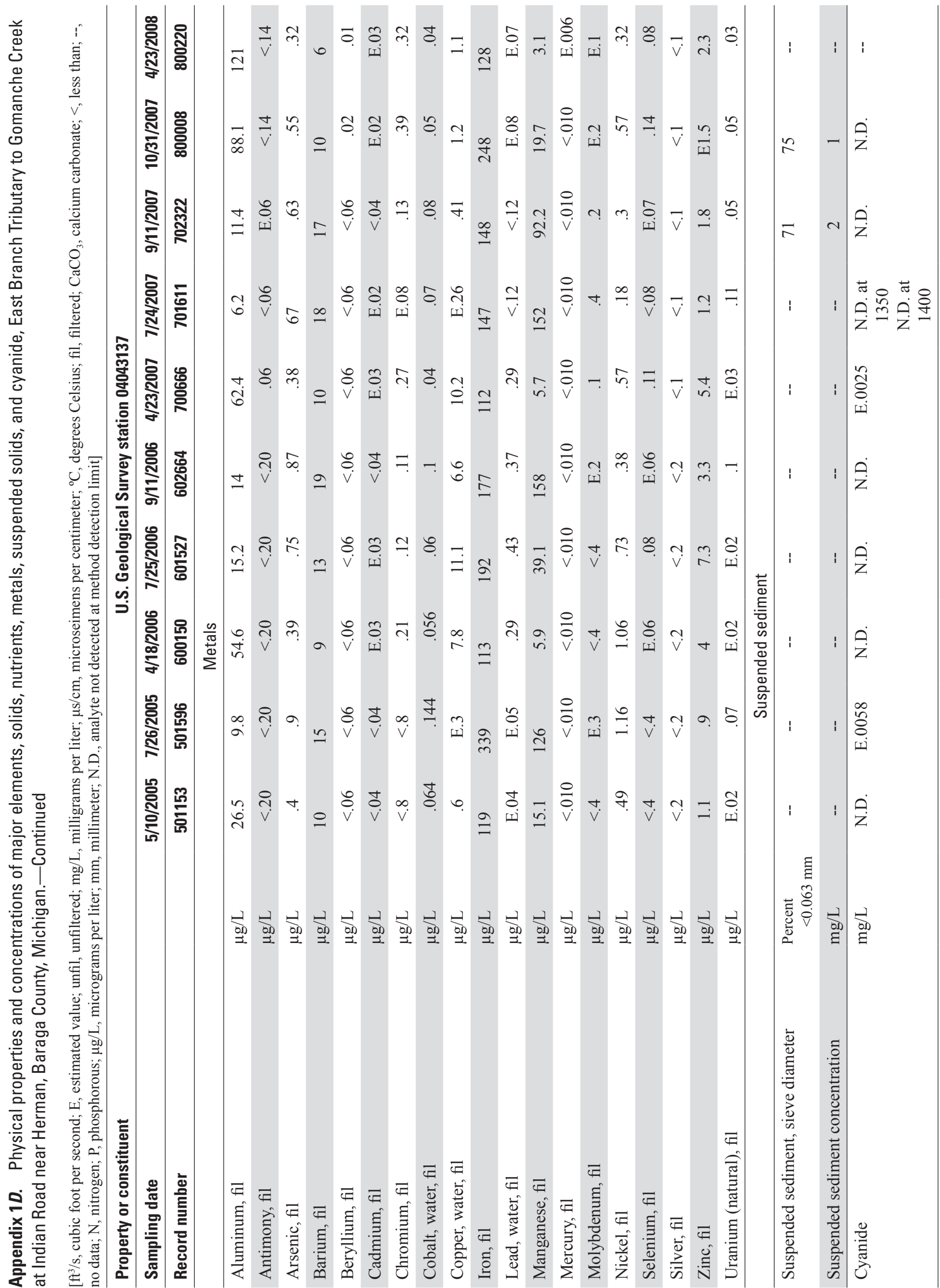




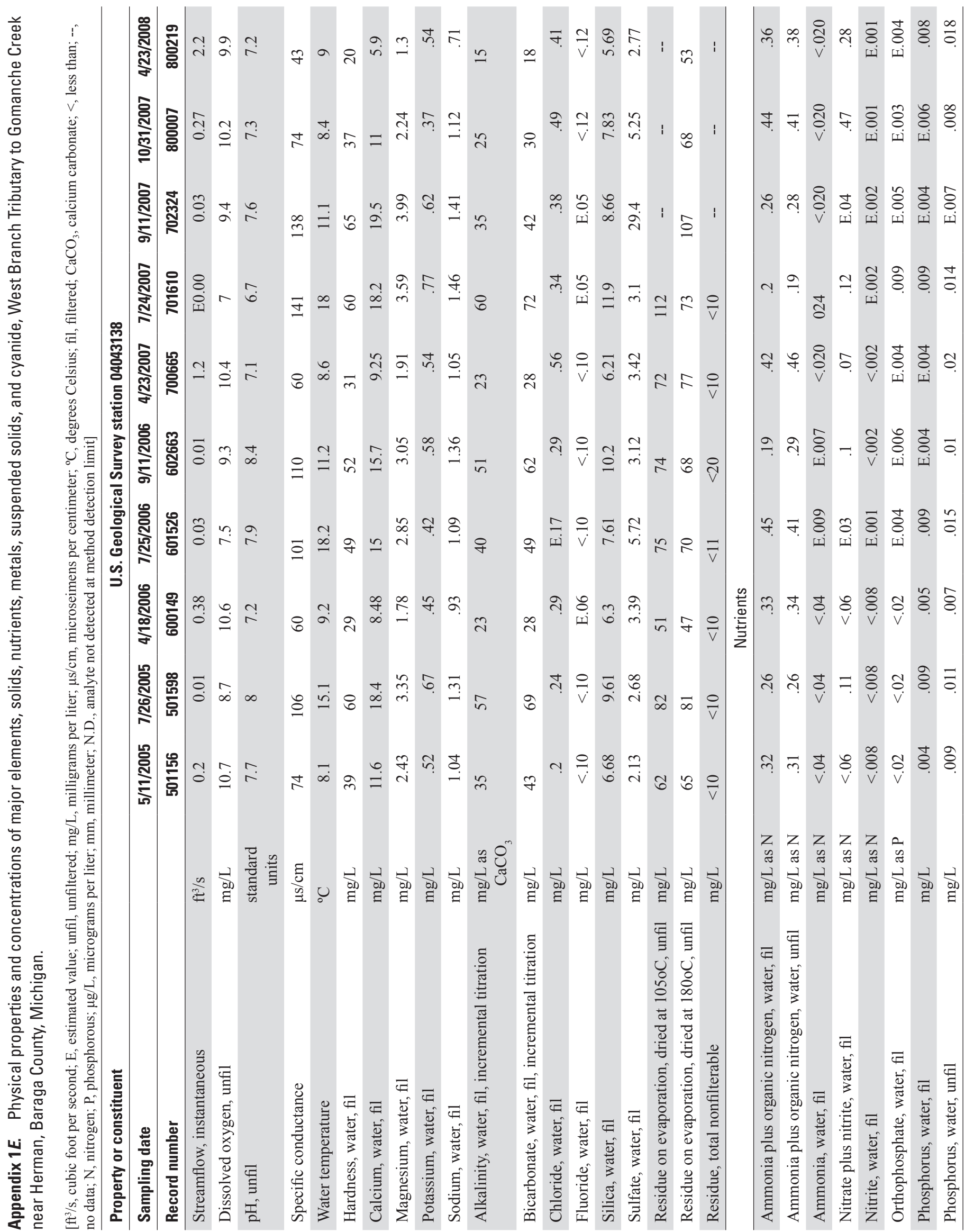




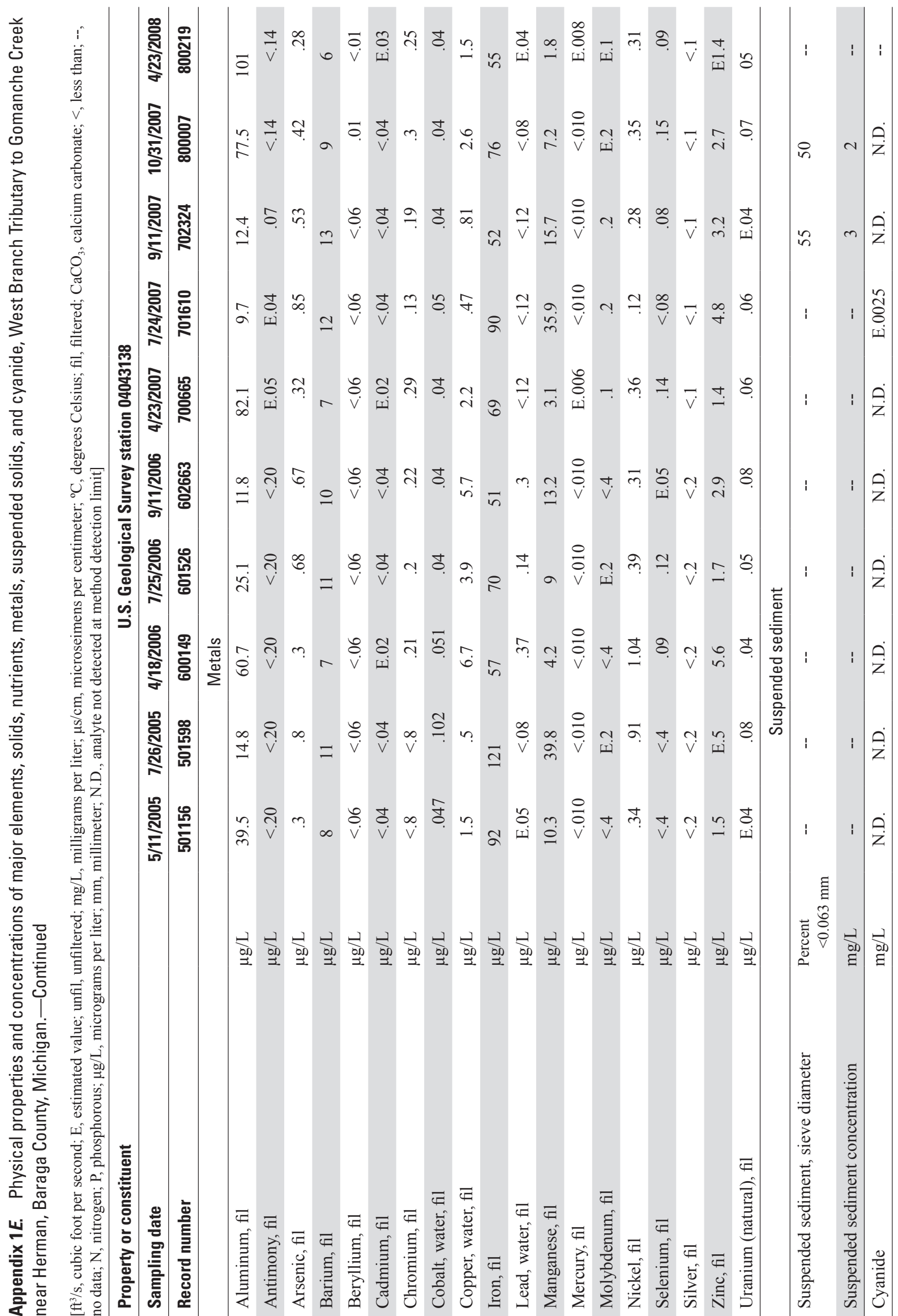




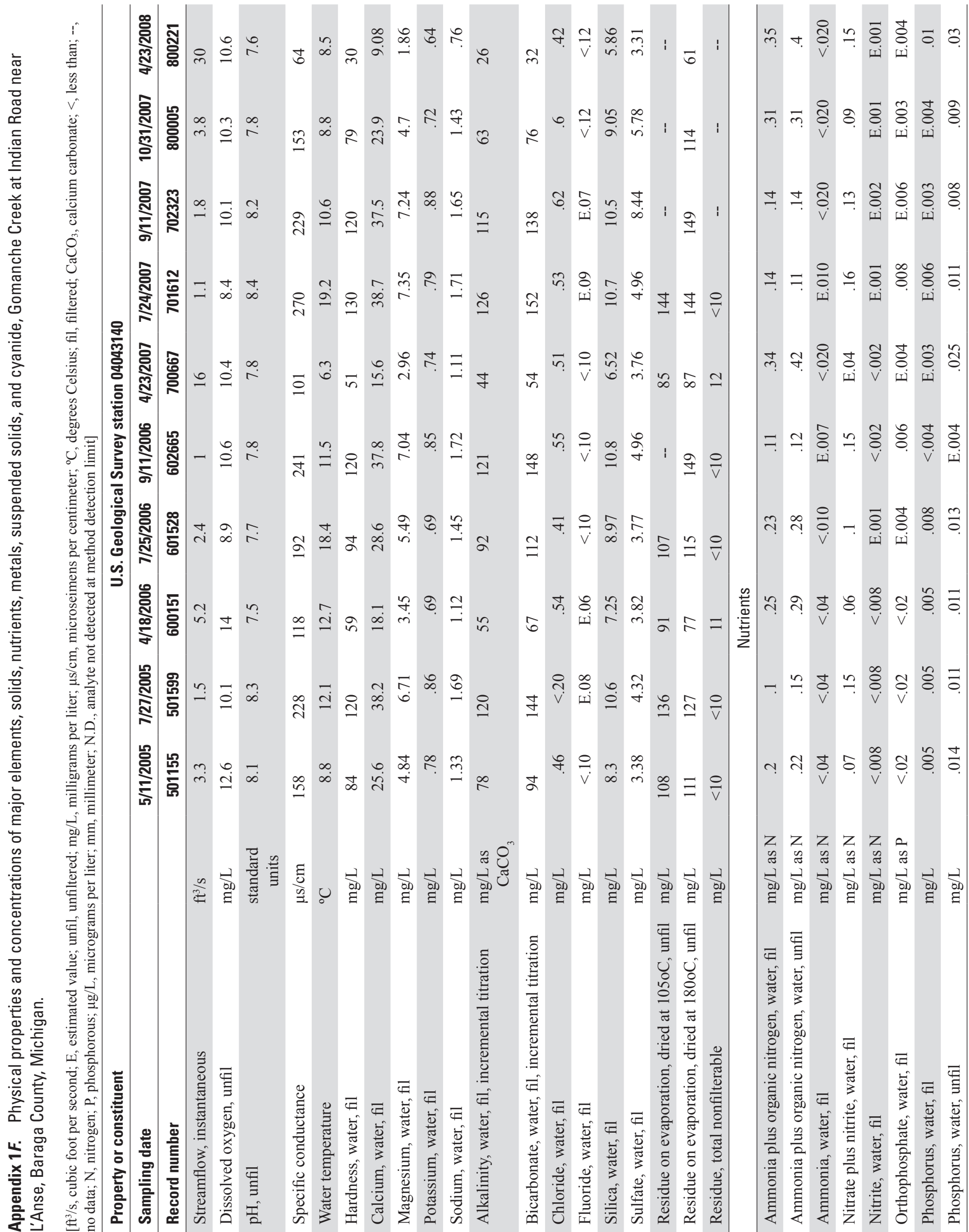




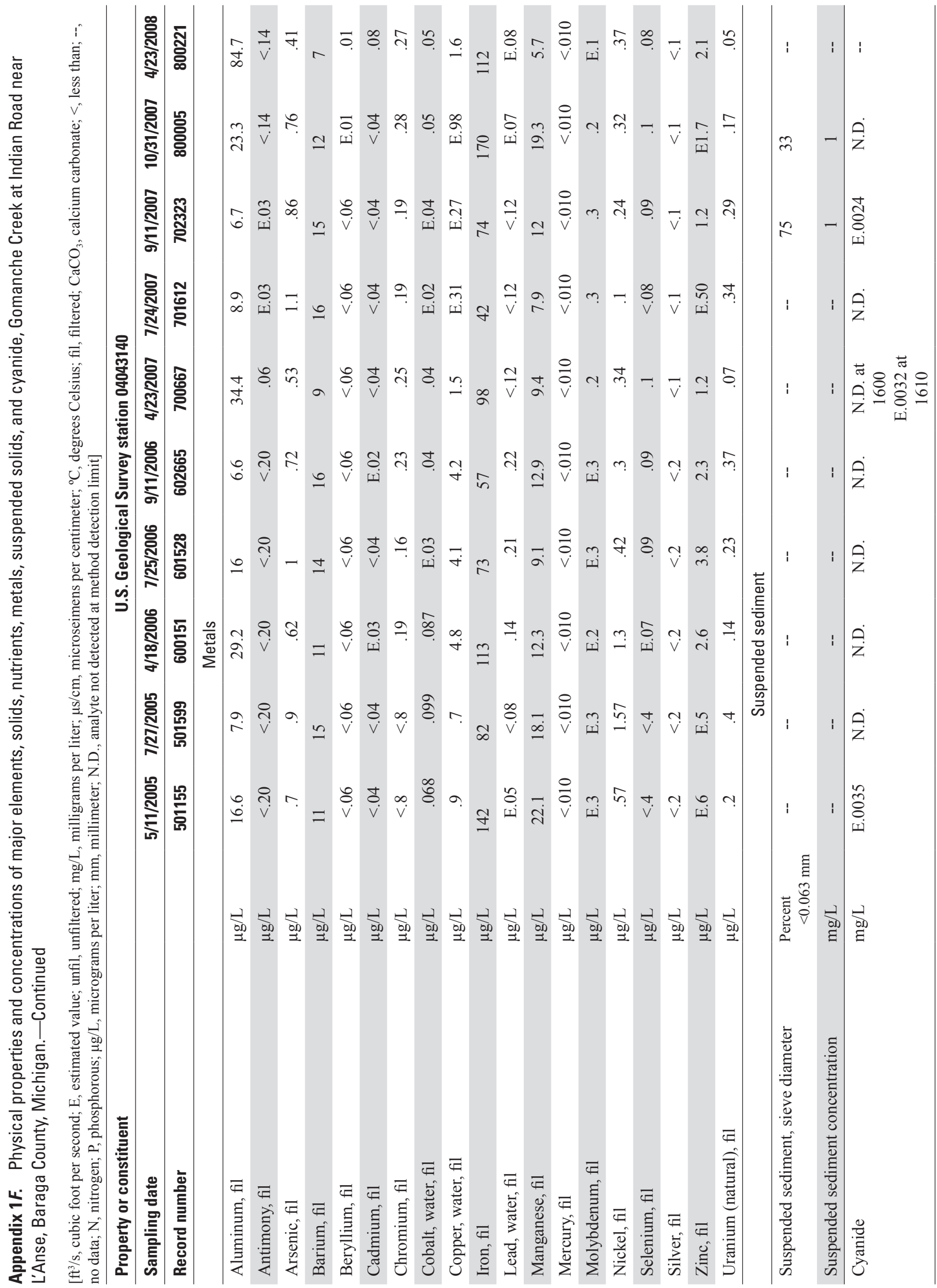




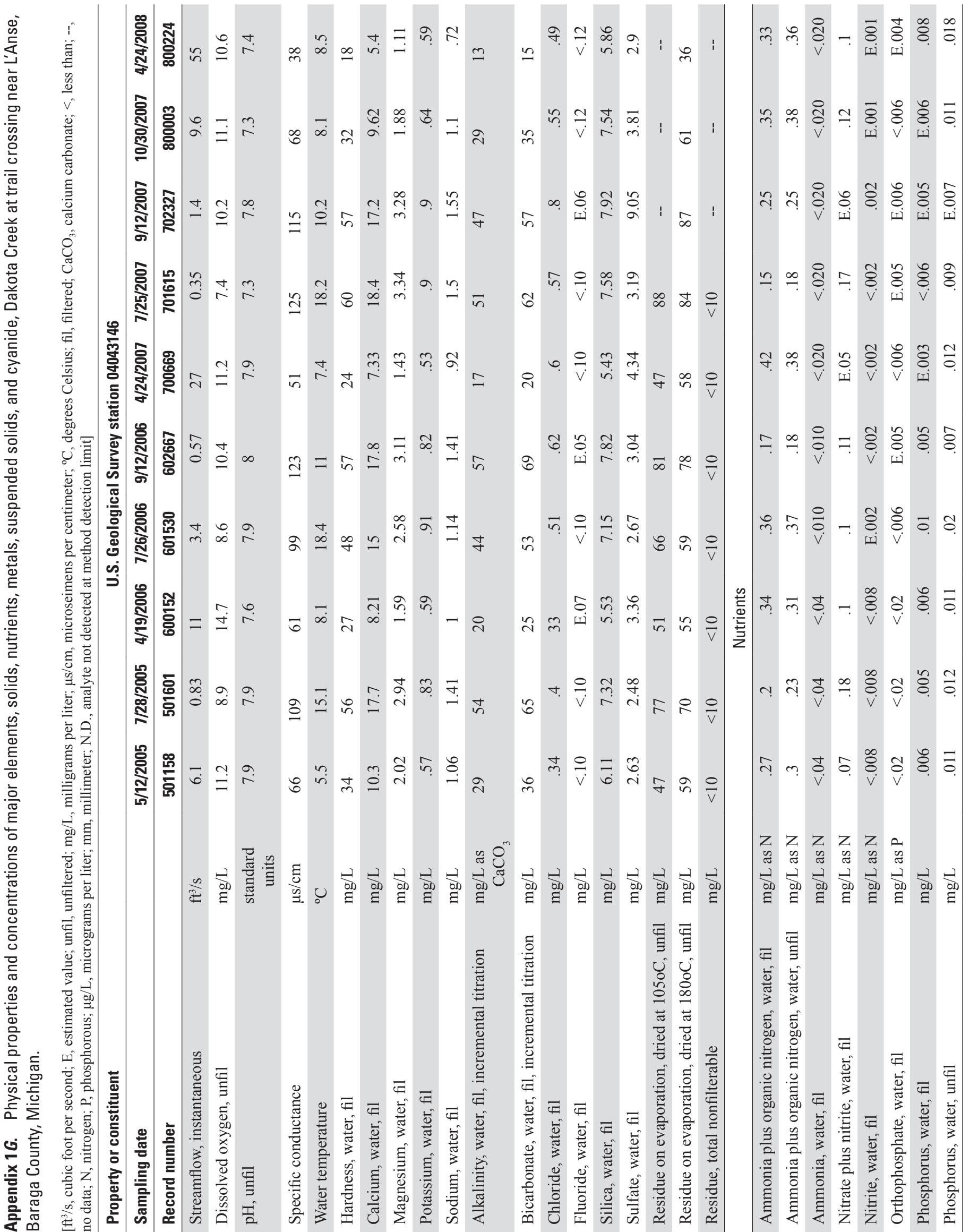




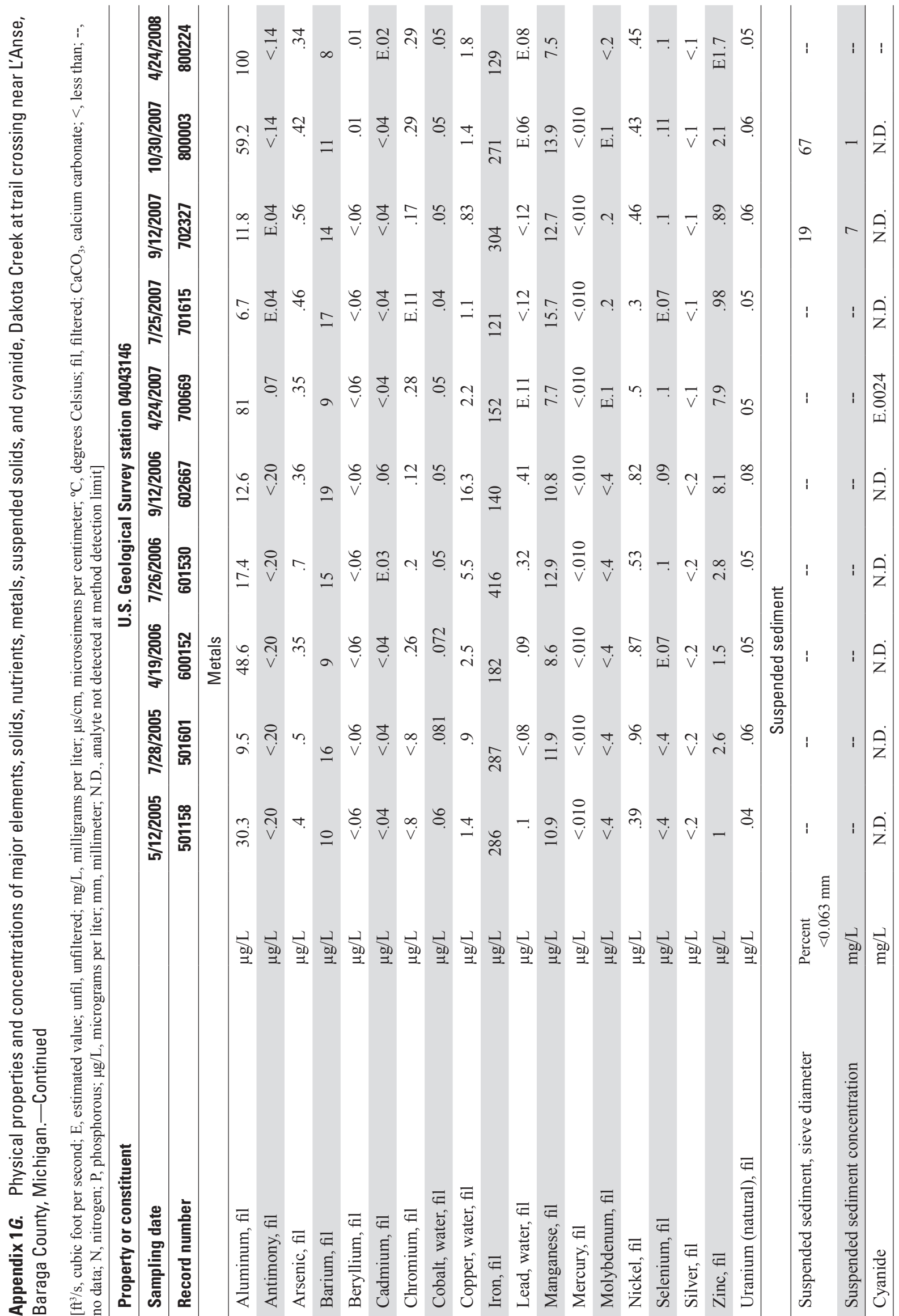




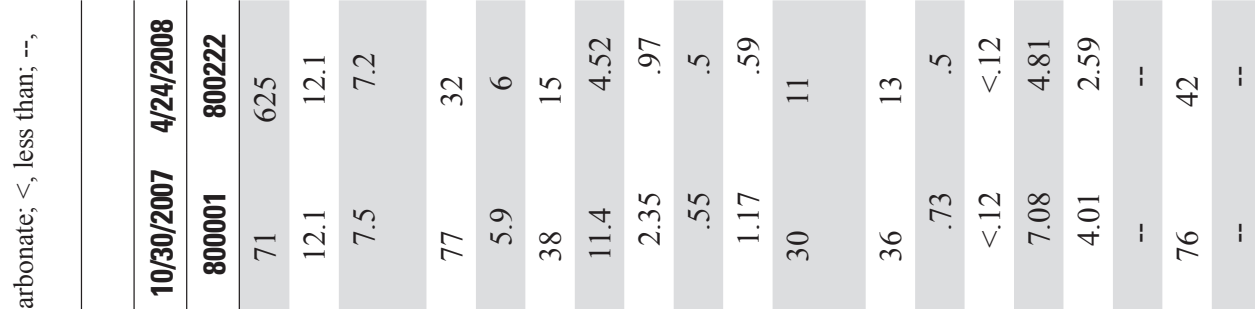

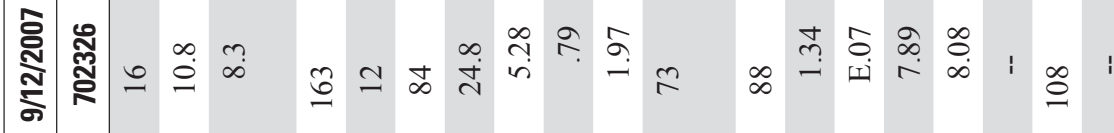

商

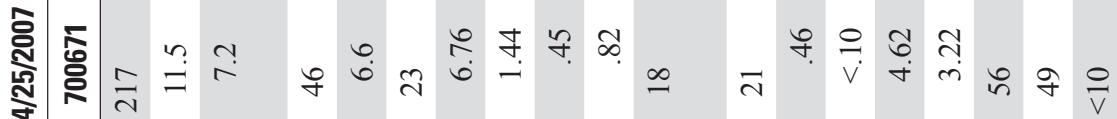

离

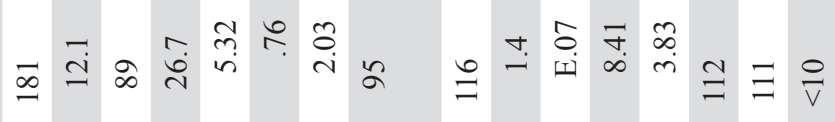

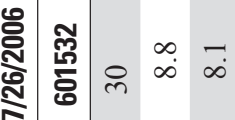

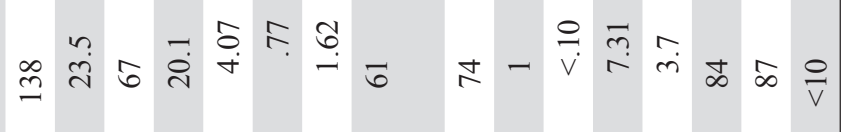

ฯ ণิ

है

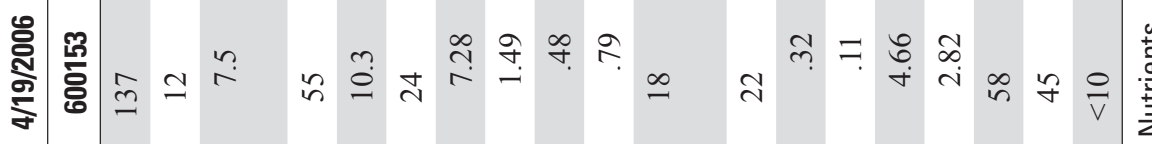

焉弯

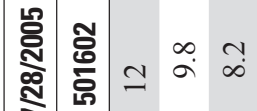

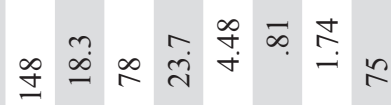

ฉ Э.

它

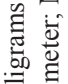

音音

秀

क्

递苛

๑

宔

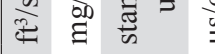

牙

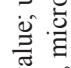

랑

急言

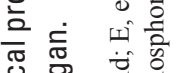

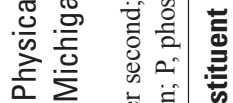
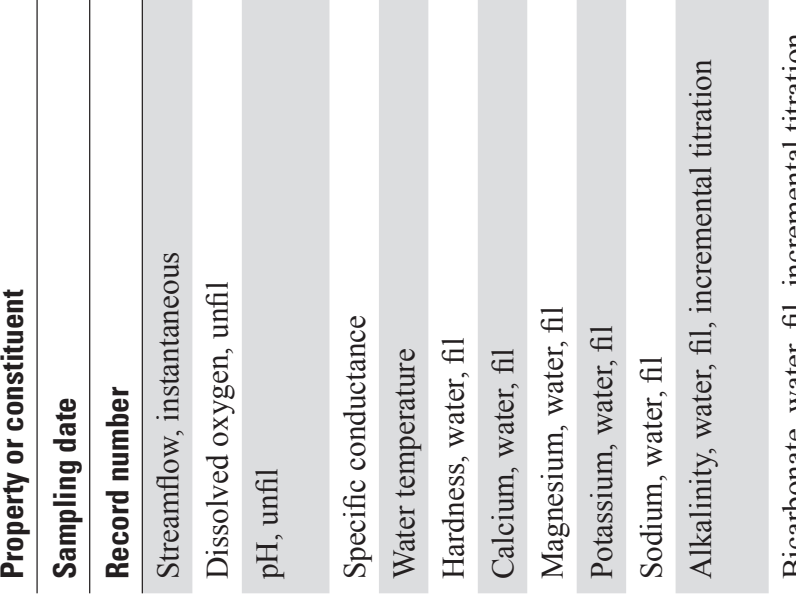

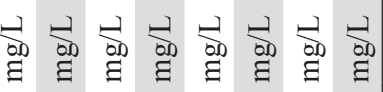

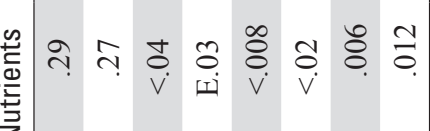

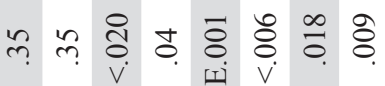

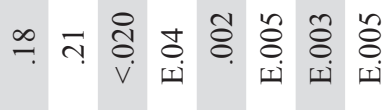

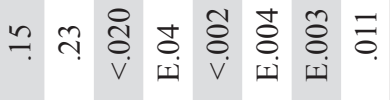

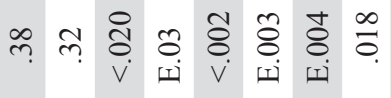

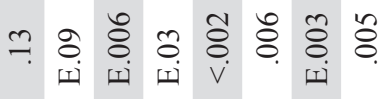

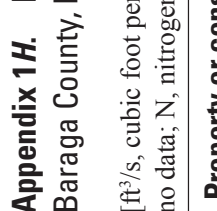
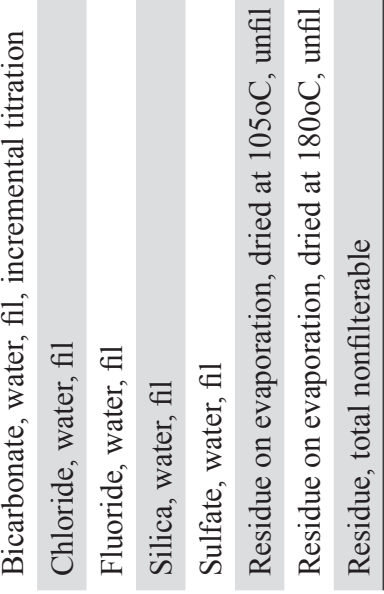

Z $\quad$ Z Z Z $\quad$ Q

శ.

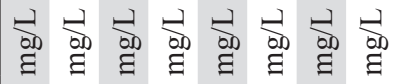

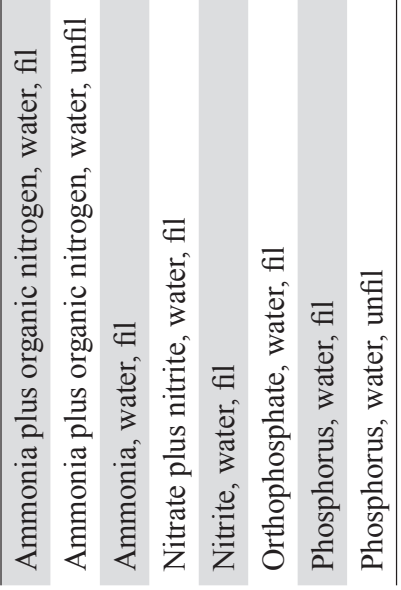




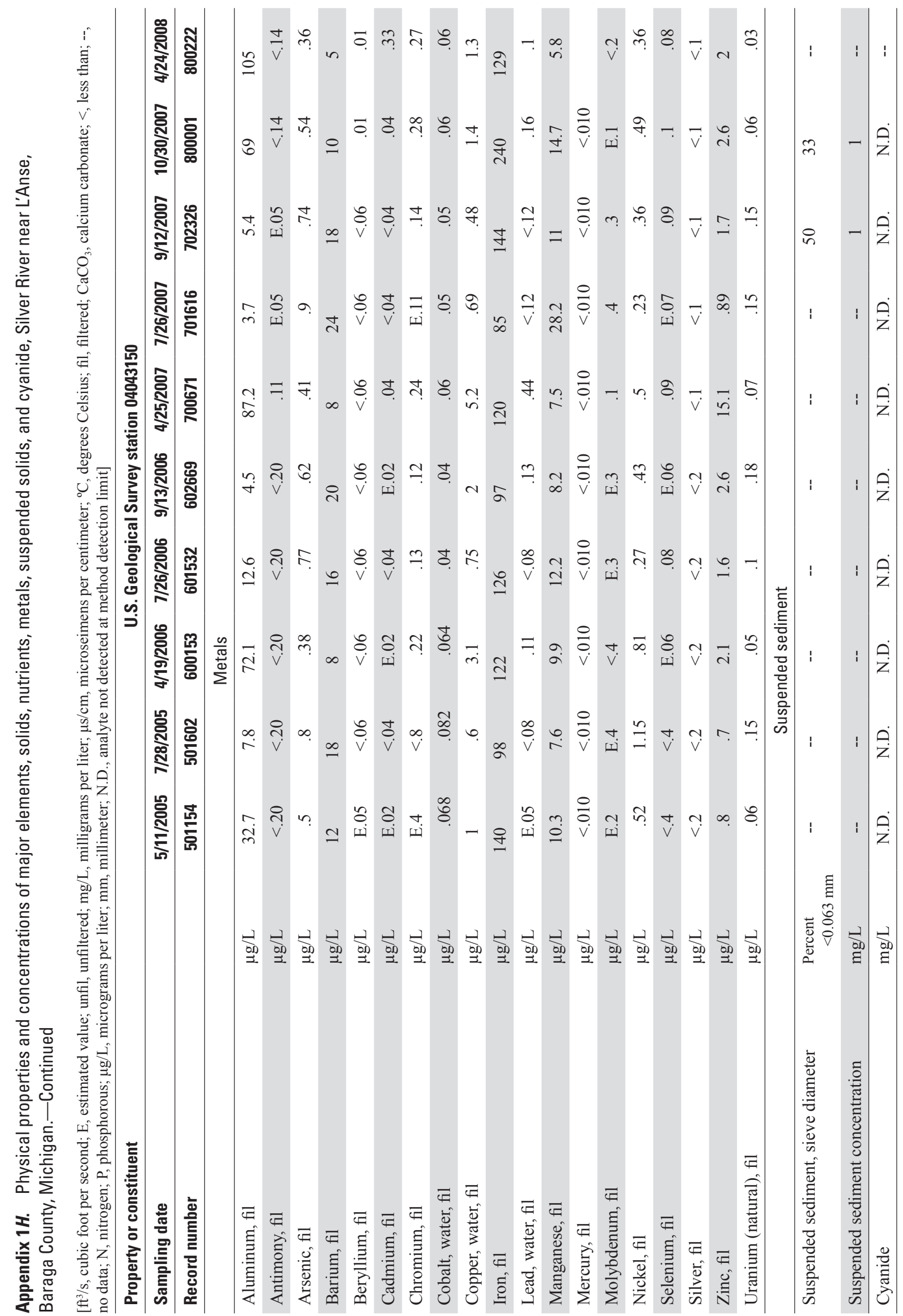




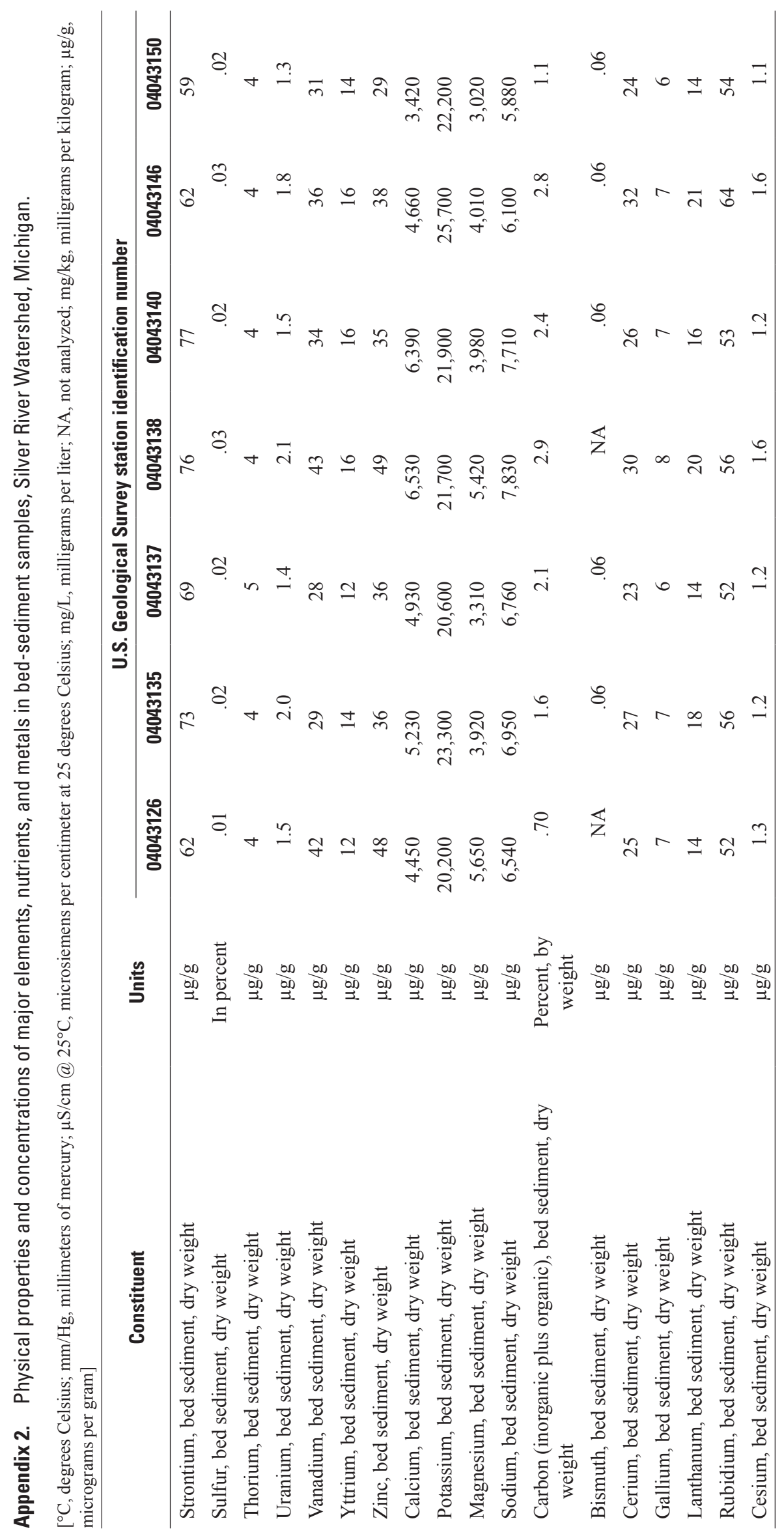


Appendix 3A. Results of macroinvertebrate sampling, Silver River upstream of East Branch near L'Anse, Baraga County, Michigan.

\begin{tabular}{|c|c|}
\hline \multicolumn{2}{|c|}{ U.S. Geological Survey station 04043126} \\
\hline Taxa & $\begin{array}{l}\text { Quantity of } \\
\text { individuals }\end{array}$ \\
\hline \multicolumn{2}{|c|}{ ARTHROPODA } \\
\hline \multicolumn{2}{|l|}{ Insecta } \\
\hline \multicolumn{2}{|l|}{ Ephemeroptera (mayflies) } \\
\hline Baetidae & 2 \\
\hline Ephemerellidae & 45 \\
\hline Heptageniidae & 33 \\
\hline Leptophlebiidae & 97 \\
\hline \multicolumn{2}{|l|}{ Odonata } \\
\hline \multicolumn{2}{|l|}{ Anisoptera (dragonflies) } \\
\hline Aeshnidae & 3 \\
\hline Cordulegastridae & 1 \\
\hline \multicolumn{2}{|l|}{ Zygoptera (damselflies) } \\
\hline Calopterygidae & 6 \\
\hline \multicolumn{2}{|l|}{ Plecoptera (stoneflies) } \\
\hline Perlodidae & 32 \\
\hline Pteronarcyidae & 4 \\
\hline \multicolumn{2}{|l|}{ Megaloptera } \\
\hline Corydalidae (dobson flies) & 5 \\
\hline \multicolumn{2}{|l|}{ Trichoptera (caddisflies) } \\
\hline Brachycentridae & 13 \\
\hline Hydropsychidae & 51 \\
\hline Limnephilidae & 3 \\
\hline Molannidae & 1 \\
\hline Philopotamidae & 22 \\
\hline \multicolumn{2}{|l|}{ Coleoptera (beetles) } \\
\hline Dytiscidae (total) & 4 \\
\hline Elmidae & 25 \\
\hline \multicolumn{2}{|l|}{ Diptera (flies) } \\
\hline Athericidae & 5 \\
\hline Chironomidae & 20 \\
\hline Simuliidae & 7 \\
\hline Tipulidae & 7 \\
\hline TOTAL INDIVIDUALS & 391 \\
\hline
\end{tabular}

Appendix 3A. Results of macroinvertebrate sampling, Silver River upstream of East Branch near L'Anse, Baraga County, Michigan. - Continued

\begin{tabular}{lcc}
\hline \multicolumn{2}{c}{ U.S. Geological Survey station 04043126} \\
\multicolumn{1}{c}{ Metric } & Value & Score \\
\hline TOTAL NUMBER OF TAXA & 22 & 0 \\
NUMBER OF MAYFLY TAXA & 4 & 0 \\
NUMBER OF CADDISFLY TAXA & 5 & 0 \\
NUMBER OF STONEFLY TAXA & 2 & 1 \\
PERCENT MAYFLY COMPOSITION & 45.27 & 1 \\
PERCENT CADDISFLY COMPOSITION & 23.02 & 0 \\
PERCENT DOMINANT TAXON & 24.81 & 0 \\
PERCENT ISOPOD, SNAIL, LEECH & 1.28 & 1 \\
PERCENT SURFACE AIR BREATHERS & 1.02 & 1 \\
\hline TOTAL SCORE & & 4 \\
\hline
\end{tabular}


Appendix 3B. Results of macroinvertebrate sampling, Silver River at Arvon Road near L'Anse, Baraga County, Michigan.

\begin{tabular}{|c|c|}
\hline \multicolumn{2}{|c|}{ U.S. Geological Survey station 04043131} \\
\hline Taxa & $\begin{array}{l}\text { Quantity of } \\
\text { individuals }\end{array}$ \\
\hline \multicolumn{2}{|c|}{ ARTHROPODA } \\
\hline \multicolumn{2}{|l|}{ Insecta } \\
\hline \multicolumn{2}{|l|}{ Ephemeroptera (mayflies) } \\
\hline Baetidae & 32 \\
\hline Ephemerellidae & 6 \\
\hline Heptageniidae & 24 \\
\hline Leptophlebiidae & 28 \\
\hline Siphlonuridae & 5 \\
\hline \multicolumn{2}{|l|}{ Odonata } \\
\hline \multicolumn{2}{|l|}{ Anisoptera (dragonflies) } \\
\hline Aeshnidae & 4 \\
\hline \multicolumn{2}{|l|}{ Plecoptera (stoneflies) } \\
\hline Pteronarcyidae & 6 \\
\hline Taeniopterygidae & 13 \\
\hline \multicolumn{2}{|l|}{ Megaloptera } \\
\hline Corydalidae (dobson flies) & 7 \\
\hline \multicolumn{2}{|l|}{ Trichoptera (caddisflies) } \\
\hline Brachycentridae & 2 \\
\hline Glossosomatidae & 2 \\
\hline Helicopsychidae & 7 \\
\hline Hydropsychidae & 1 \\
\hline Limnephilidae & 1 \\
\hline Philopotamidae & 17 \\
\hline \multicolumn{2}{|l|}{ Coleoptera (beetles) } \\
\hline Chrysomelidae (adults) & 2 \\
\hline Elmidae & 17 \\
\hline \multicolumn{2}{|l|}{ Diptera (flies) } \\
\hline Athericidae & 2 \\
\hline Ceratopogonidae & 1 \\
\hline Chironomidae & 15 \\
\hline Simuliidae & 16 \\
\hline TOTAL INDIVIDUALS & 209 \\
\hline
\end{tabular}

Appendix 3B. Results of macroinvertebrate sampling, Silver River at Arvon Road near L'Anse, Baraga County, Michigan. - Continued

\begin{tabular}{lcc}
\hline \multicolumn{1}{c}{ U.S. Geological Survey station 04043131} \\
\hline TOTAL NUMBER OF TAXA & Value & Score \\
NUMBER OF MAYFLY TAXA & 22 & 0 \\
NUMBER OF CADDISFLY TAXA & 5 & 1 \\
NUMBER OF STONEFLY TAXA & 6 & 1 \\
PERCENT MAYFLY COMPOSITION & 2 & 1 \\
PERCENT CADDISFLY COMPOSITION & 45.45 & 1 \\
PERCENT DOMINANT TAXON & 14.35 & 0 \\
PERCENT ISOPOD, SNAIL, LEECH & .48 & 1 \\
PERCENT SURFACE AIR BREATHERS & .96 & 1 \\
\hline TOTAL SCORE & & 7 \\
\hline
\end{tabular}


Appendix 3C. Results of macroinvertebrate sampling, upper Gomanche Creek at Indian Road near Herman, Baraga County, Michigan.

\section{U.S. Geological Survey station 04043135}

\begin{tabular}{|c|c|}
\hline Taxa & $\begin{array}{l}\text { Quantity of } \\
\text { individuals }\end{array}$ \\
\hline \multicolumn{2}{|c|}{ ANNELIDA (segmented worms) } \\
\hline Hirudinea (leeches) & 2 \\
\hline \multicolumn{2}{|c|}{ ARTHROPODA } \\
\hline \multicolumn{2}{|l|}{ Crustacea } \\
\hline Isopoda (sowbugs) & 1 \\
\hline \multicolumn{2}{|l|}{ Insecta } \\
\hline \multicolumn{2}{|l|}{ Ephemeroptera (mayflies) } \\
\hline Baetidae & 18 \\
\hline \multicolumn{2}{|l|}{ Caenidae } \\
\hline Ephemerellidae & 12 \\
\hline Heptageniidae & 15 \\
\hline Leptophlebiidae & 51 \\
\hline \multicolumn{2}{|l|}{ Odonata } \\
\hline \multicolumn{2}{|l|}{ Anisoptera (dragonflies) } \\
\hline Aeshnidae & 1 \\
\hline Cordulegastridae & 14 \\
\hline \multicolumn{2}{|l|}{ Plecoptera (stoneflies) } \\
\hline Capniidae & 7 \\
\hline Leuctridae & 41 \\
\hline \multicolumn{2}{|l|}{ Hemiptera (true bugs) } \\
\hline Gerridae & 2 \\
\hline \multicolumn{2}{|l|}{ Megaloptera } \\
\hline \multicolumn{2}{|c|}{ Corydalidae (dobson flies) } \\
\hline Sialidae (alder flies) & 6 \\
\hline \multicolumn{2}{|l|}{ Trichoptera (caddisflies) } \\
\hline Hydropsychidae & 8 \\
\hline Leptoceridae & 6 \\
\hline Limnephilidae & 6 \\
\hline Philopotamidae & 10 \\
\hline Polycentropodidae & 45 \\
\hline \multicolumn{2}{|l|}{ Coleoptera (beetles) } \\
\hline Elmidae & 4 \\
\hline \multicolumn{2}{|l|}{ Diptera (flies) } \\
\hline Athericidae & 1 \\
\hline Ceratopogonidae & 17 \\
\hline Chironomidae & 30 \\
\hline Simuliidae & 4 \\
\hline Tabanidae & 1 \\
\hline Tipulidae & 13 \\
\hline TOTAL INDIVIDUALS & 315 \\
\hline
\end{tabular}

Appendix 3C. Results of macroinvertebrate sampling, upper Gomanche Creek at Indian Road near Herman, Baraga County, Michigan. - Continued

\begin{tabular}{lcc}
\hline \multicolumn{3}{c}{ U.S. Geological Survey station } \\
\multicolumn{1}{c}{ 04043135 } \\
\hline TOtric & Value & Score \\
\hline NOTAL NUMBER OF TAXA & 24 & 1 \\
NUMBER OF MAYFLY TAXA & 4 & 1 \\
NUMBER OF CADDISFLY TAXA & 5 & 0 \\
NUMBER OF STONEFLY TAXA & 2 & 1 \\
PERCENT MAYFLY COMPOSITION & 30.48 & 1 \\
PERCENT CADDISFLY COMPOSITION & 23.81 & 0 \\
PERCENT DOMINANT TAXON & 16.19 & 1 \\
PERCENT ISOPOD, SNAIL, LEECH & .95 & 1 \\
PERCENT SURFACE AIR BREATHERS & .63 & 1 \\
\hline TOTAL SCORE & & 7 \\
\hline
\end{tabular}


Appendix 3D. Results of macroinvertebrate sampling, East Branch Tributary to Gomanche Creek at Indian Road near Herman,

Baraga County, Michigan.

\begin{tabular}{|c|c|}
\hline \multicolumn{2}{|c|}{ U.S. Geological Survey station 04043137} \\
\hline Taxa & $\begin{array}{l}\text { Quantity of } \\
\text { individuals }\end{array}$ \\
\hline \multicolumn{2}{|c|}{ ARTHROPODA } \\
\hline \multicolumn{2}{|l|}{ Insecta } \\
\hline \multicolumn{2}{|l|}{ Ephemeroptera (mayflies) } \\
\hline Ephemerellidae Epherella & 43 \\
\hline Heptageniidae Stenonema & 13 \\
\hline \multicolumn{2}{|l|}{ Leptophlebiidae } \\
\hline Paraleptophlebia & 39 \\
\hline \multicolumn{2}{|l|}{ Odonata } \\
\hline \multicolumn{2}{|l|}{ Anisoptera (dragonflies) } \\
\hline Cordulegastridae & 9 \\
\hline \multicolumn{2}{|l|}{ Plecoptera (stoneflies) } \\
\hline Leuctridae Leuctra & 10 \\
\hline \multicolumn{2}{|l|}{ Hemiptera (true bugs) } \\
\hline Gerridae & 2 \\
\hline \multicolumn{2}{|l|}{ Megaloptera } \\
\hline Sialidae (alder flies) & 4 \\
\hline \multicolumn{2}{|l|}{ Trichoptera (caddisflies) } \\
\hline Hydropsychidae & 34 \\
\hline Lepidostomatidae & 6 \\
\hline Philopotamidae & 10 \\
\hline Rhyacophilidae & 24 \\
\hline \multicolumn{2}{|l|}{ Coleoptera (beetles) } \\
\hline Hydrophilidae (total) & 1 \\
\hline Elmidae & 3 \\
\hline \multicolumn{2}{|l|}{ Diptera (flies) } \\
\hline Ceratopogonidae & 20 \\
\hline Chironomidae & 50 \\
\hline Ptychopteridae & 1 \\
\hline Thaumaleidae & 2 \\
\hline TOTAL INDIVIDUALS & 308 \\
\hline
\end{tabular}

Appendix 3D. Results of macroinvertebrate sampling, East Branch Tributary to Gomanche Creek at Indian Road near Herman, Baraga County, Michigan. —Continued

\begin{tabular}{lcc}
\hline \multicolumn{1}{c}{ U.S. Geological Survey station $\mathbf{0 4 0 4 3 1 3 7}$} & \\
\hline TOTAL NUMBER OF TAXA & Value & Score \\
NUMBER OF MAYFLY TAXA & 18 & 1 \\
NUMBER OF CADDISFLY TAXA & 3 & 1 \\
NUMBER OF STONEFLY TAXA & 4 & 0 \\
PERCENT MAYFLY COMPOSITION & 1 & 1 \\
PERCENT CADDISFLY COMPOSITION & 30.84 & 1 \\
PERCENT DOMINANT TAXON & 16.03 & 0 \\
PERCENT ISOPOD, SNAIL, LEECH & .00 & 1 \\
PERCENT SURFACE AIR BREATHERS & 1.30 & 1 \\
\hline TOTAL SCORE & & 7 \\
\hline
\end{tabular}


Appendix 3E. Results of macroinvertebrate sampling, West Branch Tributary to Gomanche Creek near Herman, Baraga County, Michigan.

\begin{tabular}{|c|c|}
\hline \multicolumn{2}{|c|}{ U.S. Geological Survey station 04043138} \\
\hline Taxa & $\begin{array}{l}\text { Quantity of } \\
\text { individuals }\end{array}$ \\
\hline \multicolumn{2}{|c|}{ ANNELIDA (segmented worms) } \\
\hline Oligochaeta (worms) & 2 \\
\hline \multicolumn{2}{|c|}{ ARTHROPODA } \\
\hline \multicolumn{2}{|l|}{ Insecta } \\
\hline \multicolumn{2}{|l|}{ Ephemeroptera (mayflies) } \\
\hline Baetidae & 13 \\
\hline Ephemerellidae & 82 \\
\hline Leptophlebiidae & 31 \\
\hline \multicolumn{2}{|l|}{ Odonata } \\
\hline \multicolumn{2}{|l|}{ Anisoptera (dragonflies) } \\
\hline Cordulegastridae & 2 \\
\hline \multicolumn{2}{|l|}{ Plecoptera (stoneflies) } \\
\hline Perlodidae & 15 \\
\hline \multicolumn{2}{|l|}{ Hemiptera (true bugs) } \\
\hline Gerridae & 1 \\
\hline \multicolumn{2}{|l|}{ Megaloptera } \\
\hline Corydalidae (dobson flies) & 1 \\
\hline \multicolumn{2}{|l|}{ Trichoptera (caddisflies) } \\
\hline Glossosomatidae & 6 \\
\hline Hydropsychidae & 23 \\
\hline Limnephilidae & 26 \\
\hline Molannidae & 2 \\
\hline Philopotamidae & 8 \\
\hline \multicolumn{2}{|l|}{ Coleoptera (beetles) } \\
\hline Chrysomelidae (adults) & 2 \\
\hline \multicolumn{2}{|l|}{ Diptera (flies) } \\
\hline Athericidae & 5 \\
\hline Ceratopogonidae & 1 \\
\hline Chironomidae & 84 \\
\hline Tipulidae & 7 \\
\hline \multicolumn{2}{|l|}{ MOLLUSCA } \\
\hline \multicolumn{2}{|l|}{ Pelecypoda (bivalves) } \\
\hline Unionidae (mussels) & 2 \\
\hline TOTAL INDIVIDUALS & 314 \\
\hline
\end{tabular}

Appendix 3E. Results of macroinvertebrate sampling, West Branch Tributary to Gomanche Creek near Herman, Baraga County, Michigan. - Continued

\begin{tabular}{lcc}
\hline \multicolumn{1}{c}{ U.S. Geological Survey station 04043138} \\
\hline TOTAL NUMBER OF TAXA & Value & Score \\
NUMBER OF MAYFLY TAXA & 20 & 1 \\
NUMBER OF CADDISFLY TAXA & 3 & 1 \\
NUMBER OF STONEFLY TAXA & 5 & 0 \\
PERCENT MAYFLY COMPOSITION & 1 & 1 \\
PERCENT CADDISFLY COMPOSITION & 40.13 & 1 \\
PERCENT DOMINANT TAXON & 20.70 & 0 \\
PERCENT ISOPOD, SNAIL, LEECH & .32 & 1 \\
PERCENT SURFACE AIR BREATHERS & .96 & 1 \\
\hline TOTAL SCORE & & 6 \\
\hline
\end{tabular}


Appendix 3F. Results of macroinvertebrate sampling, Gomanche Creek at Indian Road near L'Anse, Baraga County, Michigan.

\begin{tabular}{|c|c|}
\hline \multicolumn{2}{|c|}{ U.S. Geological Survey station 04043140} \\
\hline Taxa & $\begin{array}{l}\text { Quantity of } \\
\text { individuals }\end{array}$ \\
\hline \multicolumn{2}{|l|}{ ARTHROPODA } \\
\hline \multicolumn{2}{|l|}{ Insecta } \\
\hline \multicolumn{2}{|l|}{ Ephemeroptera (mayflies) } \\
\hline Baetidae Pseudocloeon & 11 \\
\hline Ephemerellidae Ephemerlla & 28 \\
\hline Heptageniidae Stenonma & 21 \\
\hline Heptageniidae Rhitrogena & 35 \\
\hline Leptophlebiidae Paralephlebia & 48 \\
\hline \multicolumn{2}{|l|}{ Odonata } \\
\hline \multicolumn{2}{|l|}{ Anisoptera (dragonflies) } \\
\hline Aeshnidae & 1 \\
\hline Cordulegastridae & 3 \\
\hline \multicolumn{2}{|l|}{ Plecoptera (stoneflies) } \\
\hline Nemouridae & 23 \\
\hline Perlodidae & 16 \\
\hline Pteronarcyidae Pteronarcella & 1 \\
\hline Taeniopterygidae & 1 \\
\hline \multicolumn{2}{|l|}{ Trichoptera (caddisflies) } \\
\hline Brachycentridae & 1 \\
\hline Glossosomatidae & 1 \\
\hline Hydropsychidae & 31 \\
\hline Polycentropodidae & 4 \\
\hline \multicolumn{2}{|l|}{ Coleoptera (beetles) } \\
\hline Elmidae & 8 \\
\hline \multicolumn{2}{|l|}{ Diptera (flies) } \\
\hline Athericidae & 29 \\
\hline Ceratopogonidae & 5 \\
\hline Chironomidae & 11 \\
\hline Ephydridae & 1 \\
\hline Simuliidae & 4 \\
\hline Tipulidae & 17 \\
\hline TOTAL INDIVIDUALS & 300 \\
\hline
\end{tabular}

Appendix 3F. Results of macroinvertebrate sampling, Gomanche Creek at Indian Road near L'Anse, Baraga County, Michigan. -Continued

\begin{tabular}{lcc}
\hline \multicolumn{1}{c}{ U.S. Geological Survey station $\mathbf{0 4 0 4 3 1 4 0}$} & \\
\hline TOTAL NUMBER OF TAXA & Value & Score \\
NUMBER OF MAYFLY TAXA & 22 & 1 \\
NUMBER OF CADDISFLY TAXA & 5 & 1 \\
NUMBER OF STONEFLY TAXA & 4 & 0 \\
PERCENT MAYFLY COMPOSITION & 4 & 0 \\
PERCENT CADDISFLY COMPOSITION & 47.67 & 0 \\
PERCENT DOMINANT TAXON & 12.33 & 0 \\
PERCENT ISOPOD, SNAIL, LEECH & .00 & 1 \\
PERCENT SURFACE AIR BREATHERS & .00 & 0 \\
\hline TOTAL SCORE & & 3 \\
\hline
\end{tabular}


Appendix 3G. Results of macroinvertebrate sampling, Dakota Creek at trail crossing near L'Anse, Baraga County, Michigan.

\begin{tabular}{|c|c|}
\hline \multicolumn{2}{|c|}{ U.S. Geological Survey station 04043146} \\
\hline Taxa & $\begin{array}{l}\text { Quantity of } \\
\text { individuals }\end{array}$ \\
\hline \multicolumn{2}{|c|}{ ANNELIDA (segmented worms) } \\
\hline Hirudinea (leeches) & 2 \\
\hline Oligochaeta (worms) & 2 \\
\hline \multicolumn{2}{|c|}{ ARTHROPODA } \\
\hline \multicolumn{2}{|l|}{ Insecta } \\
\hline \multicolumn{2}{|l|}{ Ephemeroptera (mayflies) } \\
\hline Baetidae & 3 \\
\hline Ephemerellidae & 9 \\
\hline Heptageniidae & 32 \\
\hline Leptophlebiidae & 51 \\
\hline \multicolumn{2}{|l|}{ Odonata } \\
\hline \multicolumn{2}{|l|}{ Anisoptera (dragonflies) } \\
\hline Cordulegastridae & 4 \\
\hline Gomphidae & 2 \\
\hline \multicolumn{2}{|l|}{ Plecoptera (stoneflies) } \\
\hline Peltoperlidae & 23 \\
\hline Perlidae & 13 \\
\hline Pteronarcyidae & 1 \\
\hline \multicolumn{2}{|l|}{ Hemiptera (true bugs) } \\
\hline Gerridae & 1 \\
\hline \multicolumn{2}{|l|}{ Megaloptera } \\
\hline Corydalidae (dobson flies) & 8 \\
\hline Sialidae (alder flies) & 3 \\
\hline \multicolumn{2}{|l|}{ Trichoptera (caddisflies) } \\
\hline Hydropsychidae & 31 \\
\hline Lepidostomatidae & 1 \\
\hline Limnephilidae & 6 \\
\hline Philopotamidae & 44 \\
\hline \multicolumn{2}{|l|}{ Coleoptera (beetles) } \\
\hline Elmidae & 13 \\
\hline \multicolumn{2}{|l|}{ Diptera (flies) } \\
\hline Athericidae & 19 \\
\hline Ceratopogonidae & 5 \\
\hline Chironomidae & 24 \\
\hline Simuliidae & 3 \\
\hline Tipulidae & 21 \\
\hline \multicolumn{2}{|c|}{ MOLLUSCA } \\
\hline \multicolumn{2}{|l|}{ Pelecypoda (bivalves) } \\
\hline Unionidae (mussels) & 1 \\
\hline TOTAL INDIVIDUALS & 324 \\
\hline
\end{tabular}

Appendix 3G. Results of macroinvertebrate sampling, Dakota Creek at trail crossing near L'Anse, Baraga County, Michigan. - Continued

\begin{tabular}{lcc}
\hline \multicolumn{1}{c}{ U.S. Geological Survey station 04043146} \\
\hline TOTAL NUMBER OF TAXA & Value & Score \\
NUMBER OF MAYFLY TAXA & 26 & 1 \\
NUMBER OF CADDISFLY TAXA & 4 & 1 \\
NUMBER OF STONEFLY TAXA & 4 & 0 \\
PERCENT MAYFLY COMPOSITION & 3 & 1 \\
PERCENT CADDISFLY COMPOSITION & 29.32 & 1 \\
PERCENT DOMINANT TAXON & 15.31 & 0 \\
PERCENT ISOPOD, SNAIL, LEECH & 1.23 & 1 \\
PERCENT SURFACE AIR BREATHERS & .31 & 1 \\
\hline TOTAL SCORE & & 7 \\
\hline
\end{tabular}


Appendix 3H. Results of macroinvertebrate sampling, Silver River near L'Anse,

Baraga County, Michigan.

\begin{tabular}{|c|c|}
\hline \multicolumn{2}{|c|}{ U.S. Geological Survey station 04043150} \\
\hline Taxa & $\begin{array}{l}\text { Quantity of } \\
\text { individuals }\end{array}$ \\
\hline PORIFERA (sponges) & 1 \\
\hline \multicolumn{2}{|c|}{ ANNELIDA (segmented worms) } \\
\hline Oligochaeta (worms) & 3 \\
\hline \multicolumn{2}{|c|}{ ARTHROPODA } \\
\hline \multicolumn{2}{|l|}{ Insecta } \\
\hline \multicolumn{2}{|l|}{ Ephemeroptera (mayflies) } \\
\hline Baetiscidae & 2 \\
\hline Baetidae & 9 \\
\hline Ephemerellidae & 11 \\
\hline Heptageniidae & 77 \\
\hline Leptophlebiidae & 37 \\
\hline \multicolumn{2}{|l|}{ Odonata } \\
\hline \multicolumn{2}{|l|}{ Anisoptera (dragonflies) } \\
\hline Cordulegastridae & 1 \\
\hline Gomphidae & 5 \\
\hline \multicolumn{2}{|l|}{ Zygoptera (damselflies) } \\
\hline Calopterygidae & 1 \\
\hline \multicolumn{2}{|l|}{ Plecoptera (stoneflies) } \\
\hline Perlidae & 9 \\
\hline Perlodidae & 9 \\
\hline \multicolumn{2}{|l|}{ Megaloptera } \\
\hline Corydalidae (dobson flies) & 10 \\
\hline \multicolumn{2}{|l|}{ Trichoptera (caddisflies) } \\
\hline Brachycentridae & 6 \\
\hline Helicopsychidae & 10 \\
\hline Hydropsychidae & 86 \\
\hline Lepidostomatidae & 4 \\
\hline Limnephilidae & 5 \\
\hline Philopotamidae & 13 \\
\hline \multicolumn{2}{|l|}{ Coleoptera (beetles) } \\
\hline Elmidae & 44 \\
\hline \multicolumn{2}{|l|}{ Diptera (flies) } \\
\hline Athericidae & 7 \\
\hline Ceratopogonidae & 4 \\
\hline Chironomidae & 18 \\
\hline Culicidae & 1 \\
\hline Simuliidae & 1 \\
\hline Tipulidae & 13 \\
\hline TOTAL INDIVIDUALS & 388 \\
\hline
\end{tabular}

Appendix $3 \boldsymbol{H}$. Results of macroinvertebrate sampling, Silver River near L'Anse, Baraga County, Michigan. —Continued

\begin{tabular}{lcc}
\hline \multicolumn{1}{c}{ U.S. Geological Survey station $\mathbf{0 4 0 4 3 1 5 0}$} \\
\hline TOTAL NUMBER OF TAXA & Value & Score \\
NUMBER OF MAYFLY TAXA & 27 & 0 \\
NUMBER OF CADDISFLY TAXA & 5 & 1 \\
NUMBER OF STONEFLY TAXA & 6 & 1 \\
PERCENT MAYFLY COMPOSITION & 2 & 1 \\
PERCENT CADDISFLY COMPOSITION & 35.05 & 1 \\
PERCENT DOMINANT TAXON & 22.16 & 1 \\
PERCENT ISOPOD, SNAIL, LEECH & .26 & 1 \\
PERCENT SURFACE AIR BREATHERS & .26 & 1 \\
\hline TOTAL SCORE & & 7 \\
\hline
\end{tabular}



(97) Printed on recycled paper 